\title{
Guidelines and Standard Procedures for Continuous Water-Quality Monitors: Site Selection, Field Operation, Calibration, Record Computation, and Reporting
}

U.S. Geological Survey

Water-Resources Investigations Report 00-4252

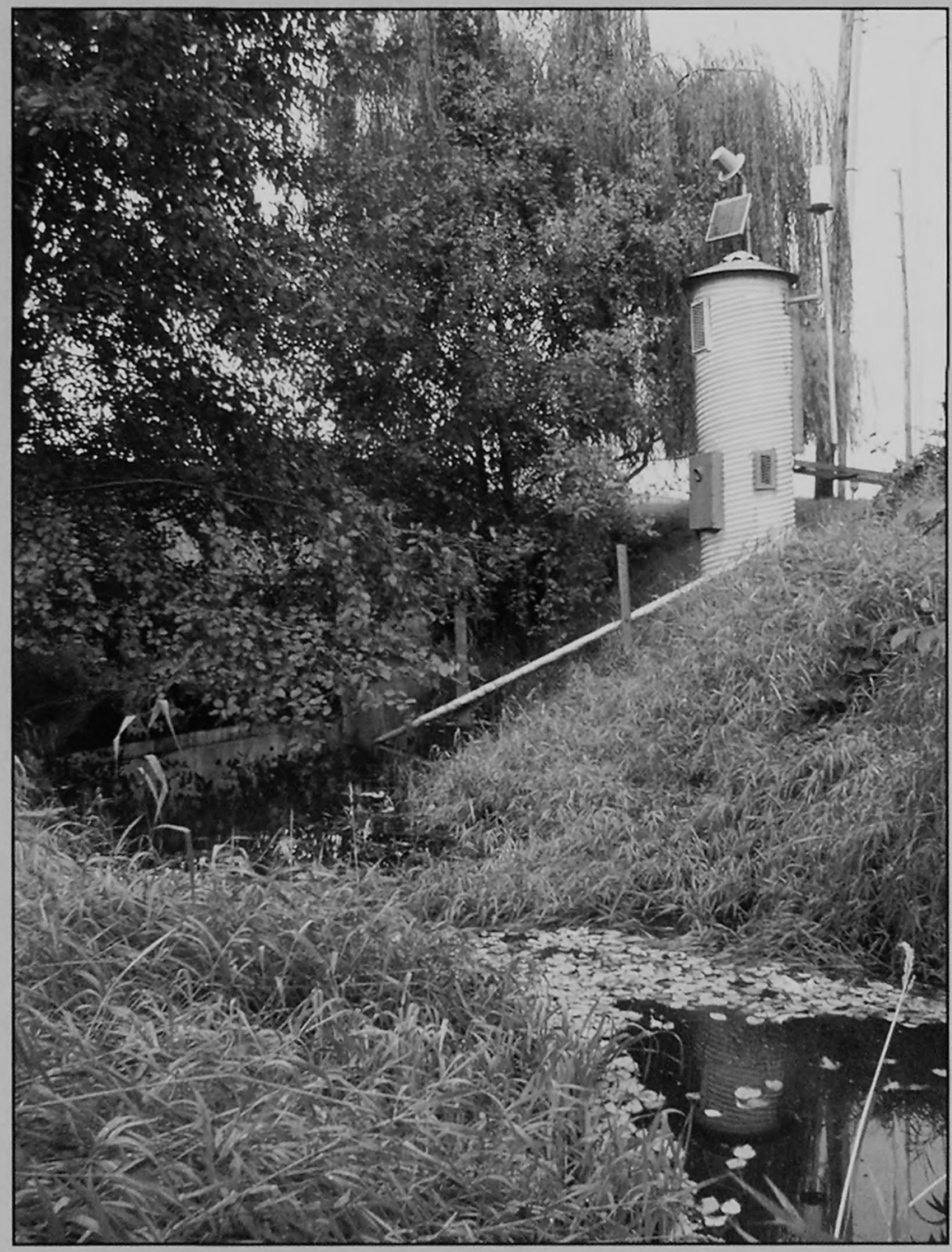


Cover photograph: Spring Brook Creek at Orillia, Washington, taken by David K. Mullis. 


\section{Guidelines and Standard Procedures for Continuous Water-Quality Monitors: Site Selection, Field Operation, Calibration, Record Computation, and Reporting}

By Richard J. Wagner, Harold C. Mattraw, George F. Ritz, and Brett A. Smith

U.S. GEOLOGICAL SURVEY $\mid$\begin{tabular}{c|c}
$\overline{\text { U.S. GEOLOGICAL SURVEY }}$ RESTON.VA \\
DEC 152000 \\
SR \\
SIBRARY
\end{tabular}

Water-Resources Investigations Report 00-4252

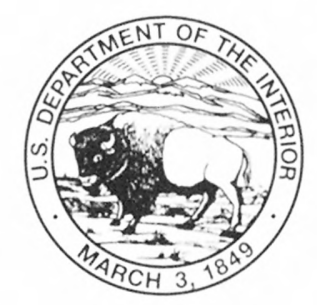




\title{
U.S. DEPARTMENT OF THE INTERIOR BRUCE BABBITT, Secretary
}

\author{
U.S. GEOLOGICAL SURVEY
}

Charles G. Groat, Director

The use of firm, trade, and brand names in this report is for identification purposes only and does not constitute endorsement by the U.S. Geological Survey.

For additional information write to:

Copies of this report can be purchased from:

Chief, Office of Water Quality U.S. Geological Survey

412 National Center

Reston, VA 20192

U.S. Geological Survey

Branch of Information Services

Box 25286, Federal Center

Denver, CO 80225 


\section{CONTENTS}

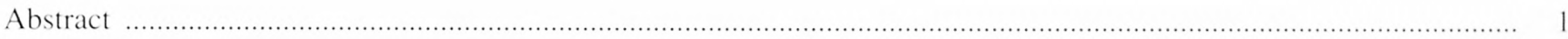

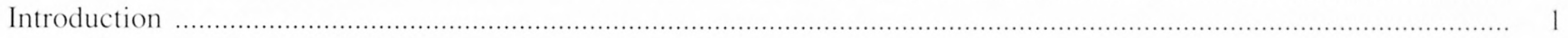

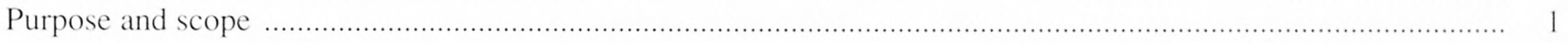

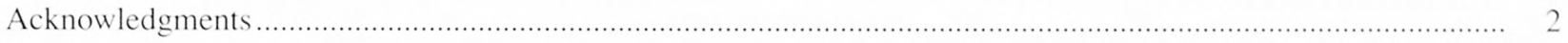

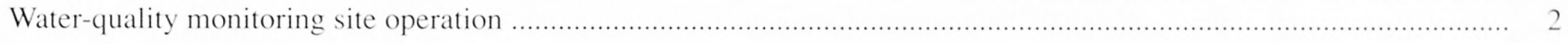

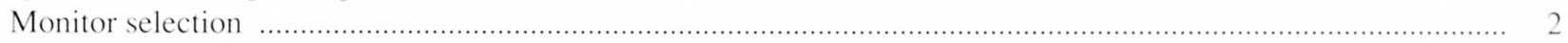

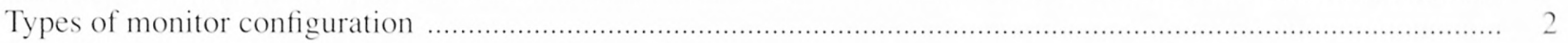

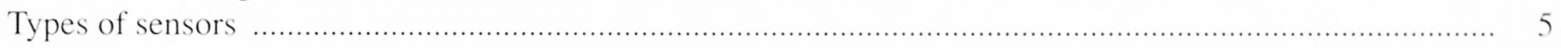

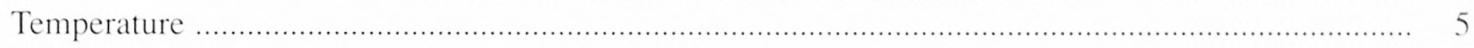

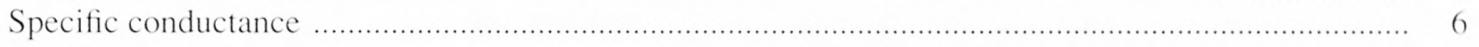

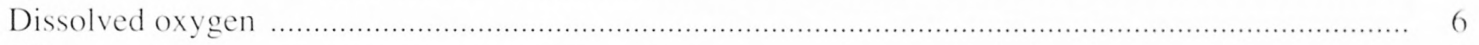

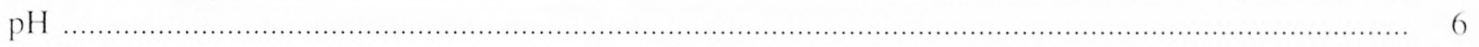

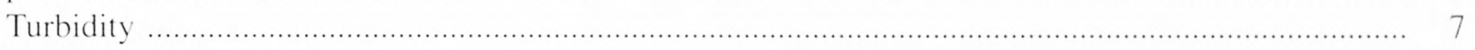

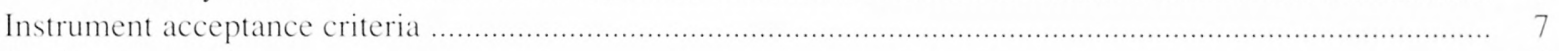

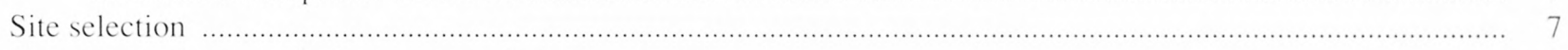

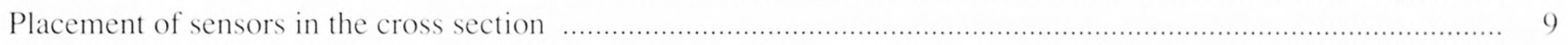

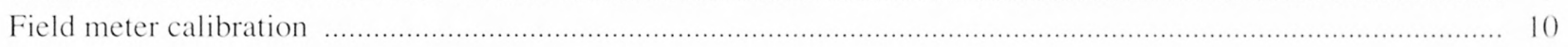

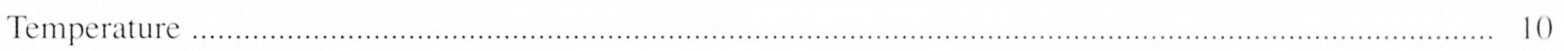

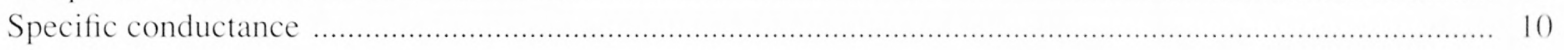

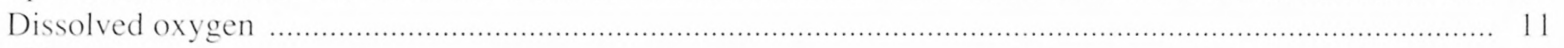

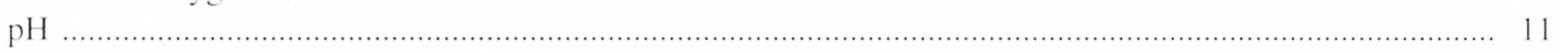

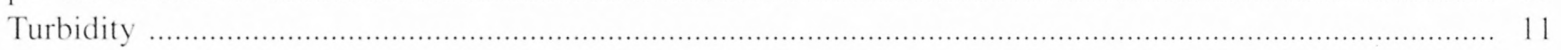

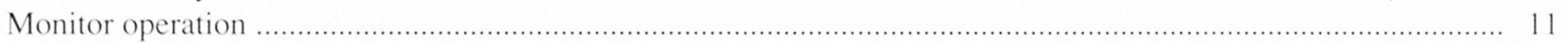

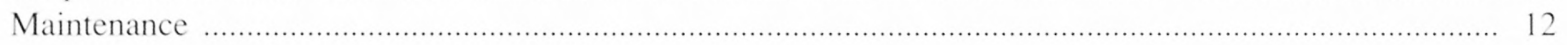

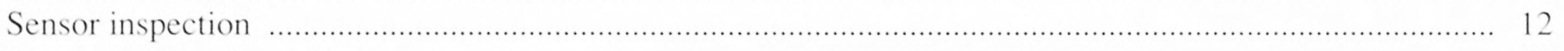

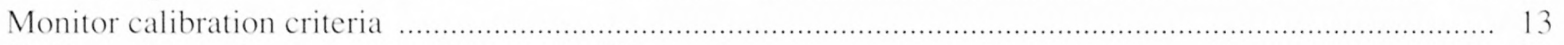

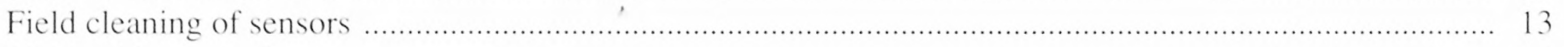

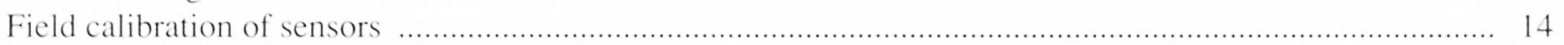

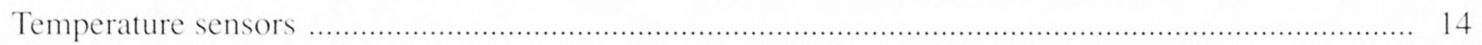

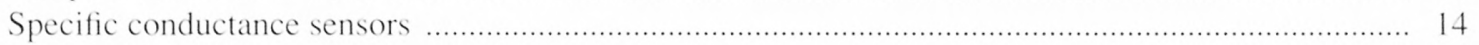

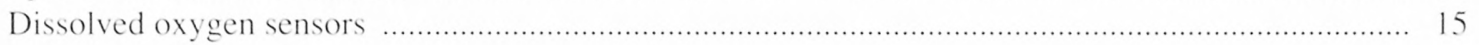

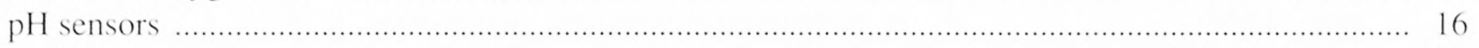

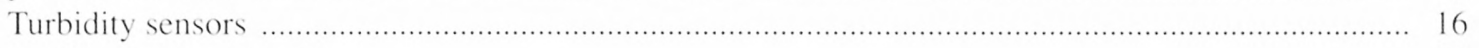

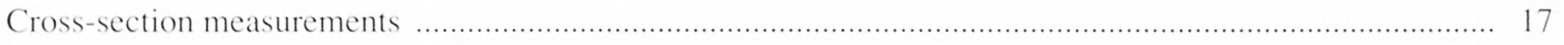

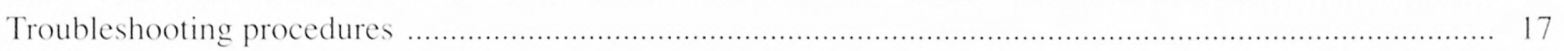

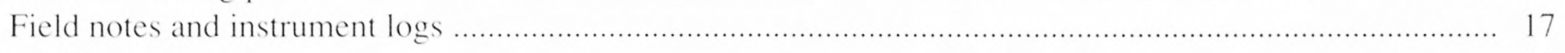

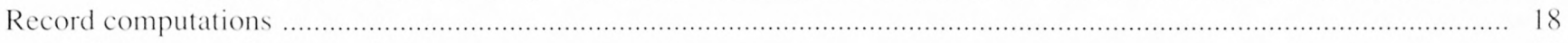

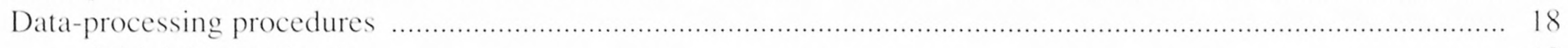

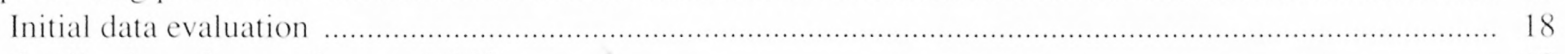

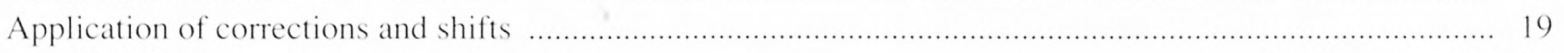

Fouling …

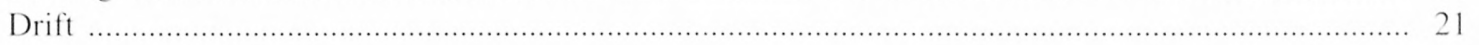

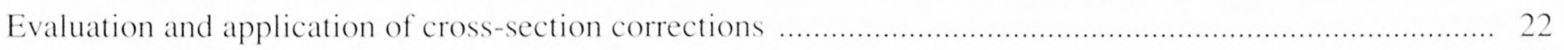

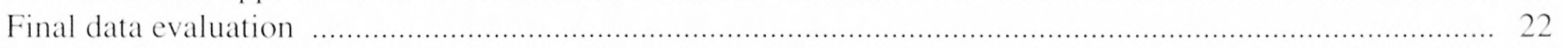

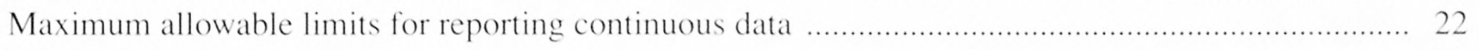

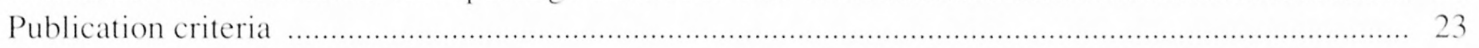

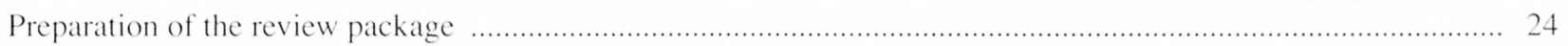

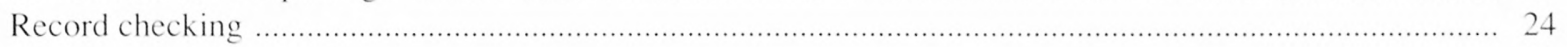

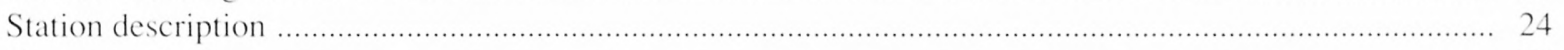

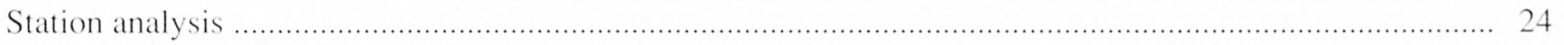




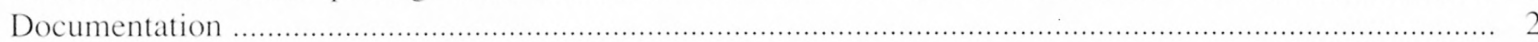

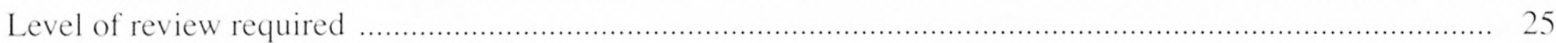

Publication

Data reports

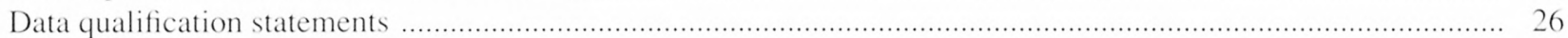

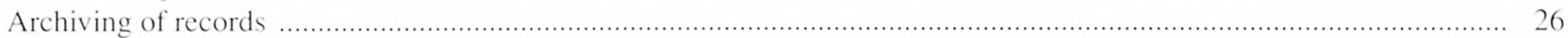

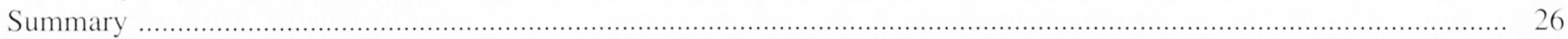

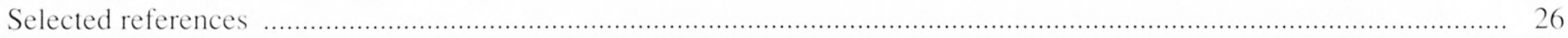

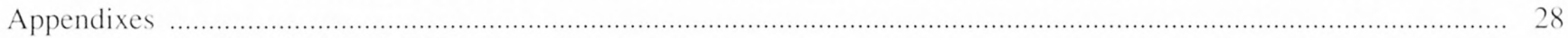

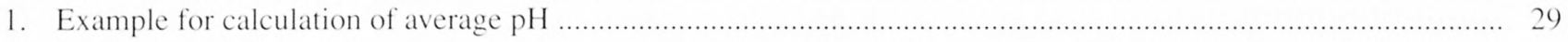

2. Station description: (A) contents of a station description, and (B) example of a station description for the Columbia River at Beaver Army Terminal near Quincy, Oregon ............................................ 30

3. Station analysis: (A) contents of a station analysis, and (B) example of a station analysis for temperature on the Columbia River at Beaver Army Terminal near Quincy, Oregon .......................................34

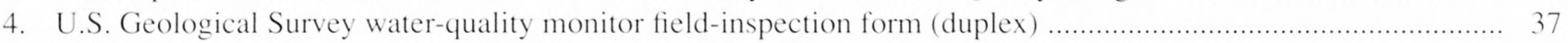

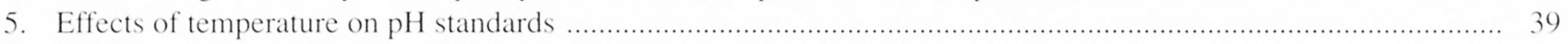

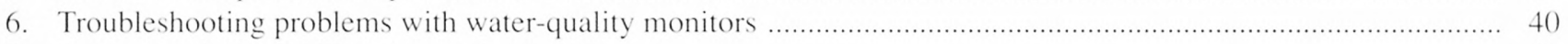

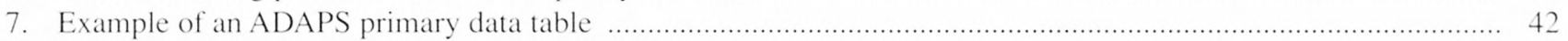

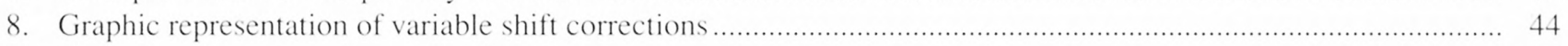

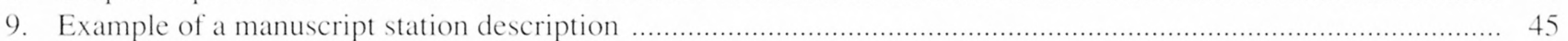

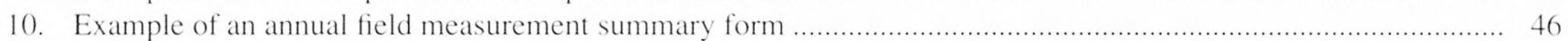

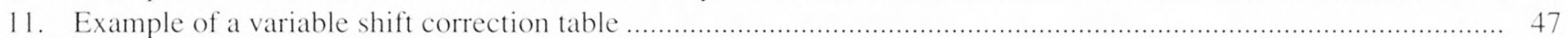

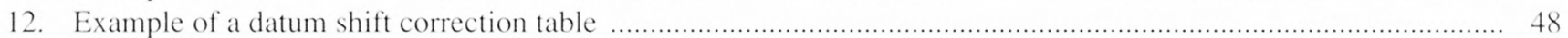

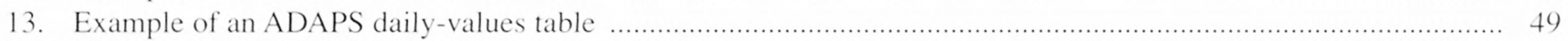

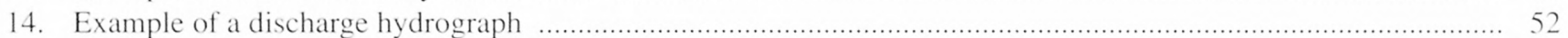

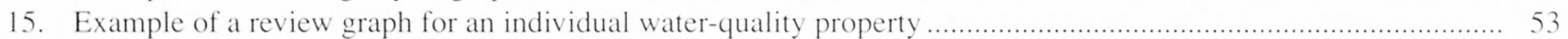

\section{Figures}

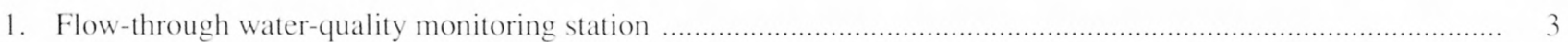

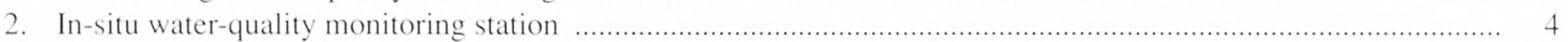

3. Self-contained water-quality monitoring sensor and recording system ....................................................... 5

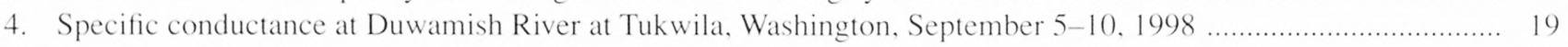

5. Generalized graph of corrections to continuous temperature record …......................................................... 21

\section{Tables}

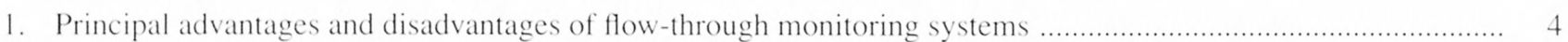

2. Principal advantages and disadvantages of in-situ monitoring systems …............................................... 4

3. Principal advantages and disadvantages of the self-contained monitoring system ........................................... 5

4. Factors for consideration in the placement and installation of continuous water-quality monitoring systems

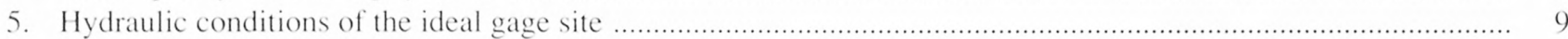

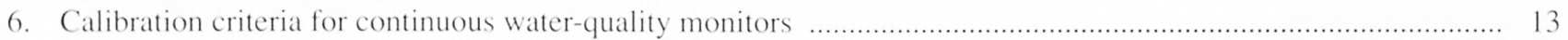

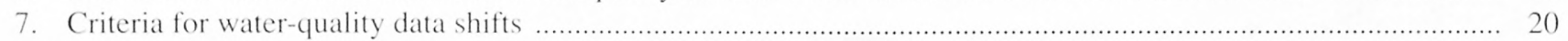

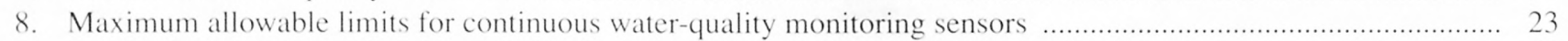

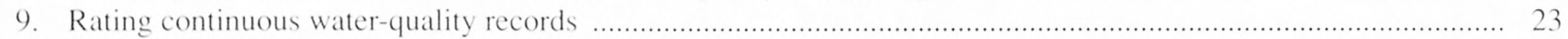




\title{
Guidelines and Standard Procedures for Continuous Water-Quality Monitors: Site Selection, Field Operation, Calibration, Record Computation, and Reporting
}

\author{
By Richard J. Wagner, Harold C. Mattraw, George F. Ritz, and Brett A. Smith
}

\section{ABSTRACT}

The U.S. Geological Survey uses continuous water-quality monitors to assess variations in the quality of the Nation's surface water. A common system configuration for data collection is the four-parameter water-quality monitoring system, which collects temperature, specific conductance, dissolved oxygen, and $\mathrm{pH}$ data, although systems can be configured to measure other properties such as turbidity or chlorophyll. The sensors that are used to measure these water properties require careful field observation, cleaning, and calibration procedures, as well as thorough procedures for the computation and publication of final records.

Data from sensors can be used in conjunction with collected samples and chemical analyses to estimate chemical loads. This report provides guidelines for site-selection considerations, sensor test methods, field procedures, error correction, data computation, and review and publication processes. These procedures have evolved over the past three decades, and the process continues to evolve with newer technologies.

\section{INTRODUCTION}

Water quality changes over time, necessitating repeated measurements to characterize variations in quality adequately. When the time interval between repeated measurements is sufficiently small, the resulting record of water quality can be considered continuous. A device that automatically measures water quality in this way is called a continuous waterquality monitor. These monitors have sensors and recording systems to measure physical and chemical water-quality properties at discrete time intervals at point locations. Operation of a water-quality monitoring station provides a nearly continuous record of water quality that can be processed and published or distributed directly by telemetry or on the World Wide Web. The water-quality record provides a nearly complete record of changes in water quality as well as a basis for computation of constituent loads at a station. Data from the sensors also can be used as surrogates for the measurement of other constituents by using regression analyses to provide estimates of instantaneous chemical loads. Emerging sensor technology is broadening the variety of measurable chemical constituents and is reducing limits of detection. As it has become possible to make near realtime water-quality monitoring data available on the World Wide Web, continual progress is being made to improve applications and refine quality-control procedures.

\section{Purpose and Scope}

This report provides basic guidelines and procedures for U.S. Geological Survey (USGS) site selection and operation of continuous water-quality monitors, field data evaluation, and subsequent record 
computations. The basic guidelines are minimal requirements that may need to be modified to meet local environmental conditions. This report provides examples of the application of scientific judgment in the evaluation of data records. Field training with the monitoring equipment and first-hand knowledge of the watershed form the core of the data-evaluation process. Record-computation procedures provide a uniform set of minimum requirements for computing records. Adoption of these water-quality record procedures will ensure that published data are properly documented.

Representative illustrations of the application of scientific judgment are, by necessity, site specific. Other specific examples are used to demonstrate the range of environmental conditions that affect the evaluation process. The final evaluation to determine portions of the record that are published requires careful review and verification of the data, but much is left to the professional judgment and observations of the hydrographer operating the station. A set of considerations that represent a sound basis for the operation of a water-quality station, data evaluation, and publication criteria is presented in this report.

\section{Acknowledgments}

The authors wish to acknowledge the support, technical contributions, and advice of USGS colleagues in the preparation of this document. Gary L. Pederson and the Southeastern Region provided technical support for production of this report. Walton H. Low, G. Douglas Glysson, and Janice R. Ward reviewed and provided important critiques of several versions of this report. Special thanks to Trudy J. Bennett and Andrew C. Ziegler for contributions to sections of the report that address turbidity and to Ann Vanderpool for input on the use of draft guidelines in the field. Kirk P. Smith provided the provisional field form used in this report, and Douglas O. Cushman assembled the Columbia River review forms.

Internal (unpublished) continuous water-quality monitoring procedures documented by the Colorado, Maine, Michigan, North Carolina, Ohio, Oregon, Texas, and Washington Districts significantly contributed to the development of these guidelines as well as previously published guidelines. Special thanks go to Brett A. Smith who co-authored an earlier version of this report and provided valuable insights to the record computation process. The encouragement of Brett, Rebecca Deckard, and Gary Pederson is gratefully acknowledged.

\section{WATER-QUALITY MONITORING SITE OPERATION}

Physical and chemical measurements in streams can be made at discrete intervals to provide a nearly continuous record of stream water quality. Major factors in the operation of a continuous water-quality site include selection of sensors and types of monitors. the type of monitor configuration, site selection, location of the sensors in the stream cross section, the use and calibration of field meters, and the actual operation of the continuous water-quality monitors. Sensor and site selection are guided by the purpose of monitoring and the data objectives. The main objective in the placement of the sensors is the selection of a stable, secure location that is representative of the stream.

\section{Monitor Selection}

The selection of a water-quality monitor involves four major interrelated elements-(1) the purpose of the data collection. (2) the type of installation, (3) the type of sensor deployed at the installation, and (4) the specific sensors needed to satisfy the accuracy and precision requirements of the data-quality objectives.

The most widely used water-quality sensors in monitoring installations are temperature, specific conductance, dissolved oxygen (DO), $\mathrm{pH}$, and turbidity. Sensors also are available to measure oxidation-reduction potential, water level, depth, salinity, ammonia, nitrate, chloride, and chlorophyll; but the focus of this report is on temperature, specific conductance, DO, pH, and turbidity. The sensors needed to measure these properties are available as single instruments or in various combinations. For clarity in this report, a sensor is referred to as a particular lone sensor or a sensor that is detachable from a combination. A group of sensors configured together commonly is referred to as a sonde, which typically has a single recording unit or electronic data logger to record the output from the multiple sensors.

\section{Types of Monitor Configuration}

In general, three types of configurations are used for water-quality monitors. The flow-through monitoring system generally has a pump that delivers water to the sensor(s) mounted in a shelter; the second configuration is one in which the sensors are placed in 
situ (immersing a field measurement sensor directly into the water); and the third configuration is a selfcontained sensor and recording system that requires no external power and is placed in situ. Each configuration has advantages and disadvantages in relation to site location and data-quality objectives.

The flow-through monitoring system has a pump to convey water from the stream to a tank inside a shelter that contains the monitoring sensor or sonde (fig. 1). Typical pumps require 120 -volt alternating current (AC) and deliver about 10 gallons of water per minute. If access to power is not a problem, then other site considerations become important (table 1); the advantages and disadvantages of the flow-through monitoring system must be compared to the data objectives.
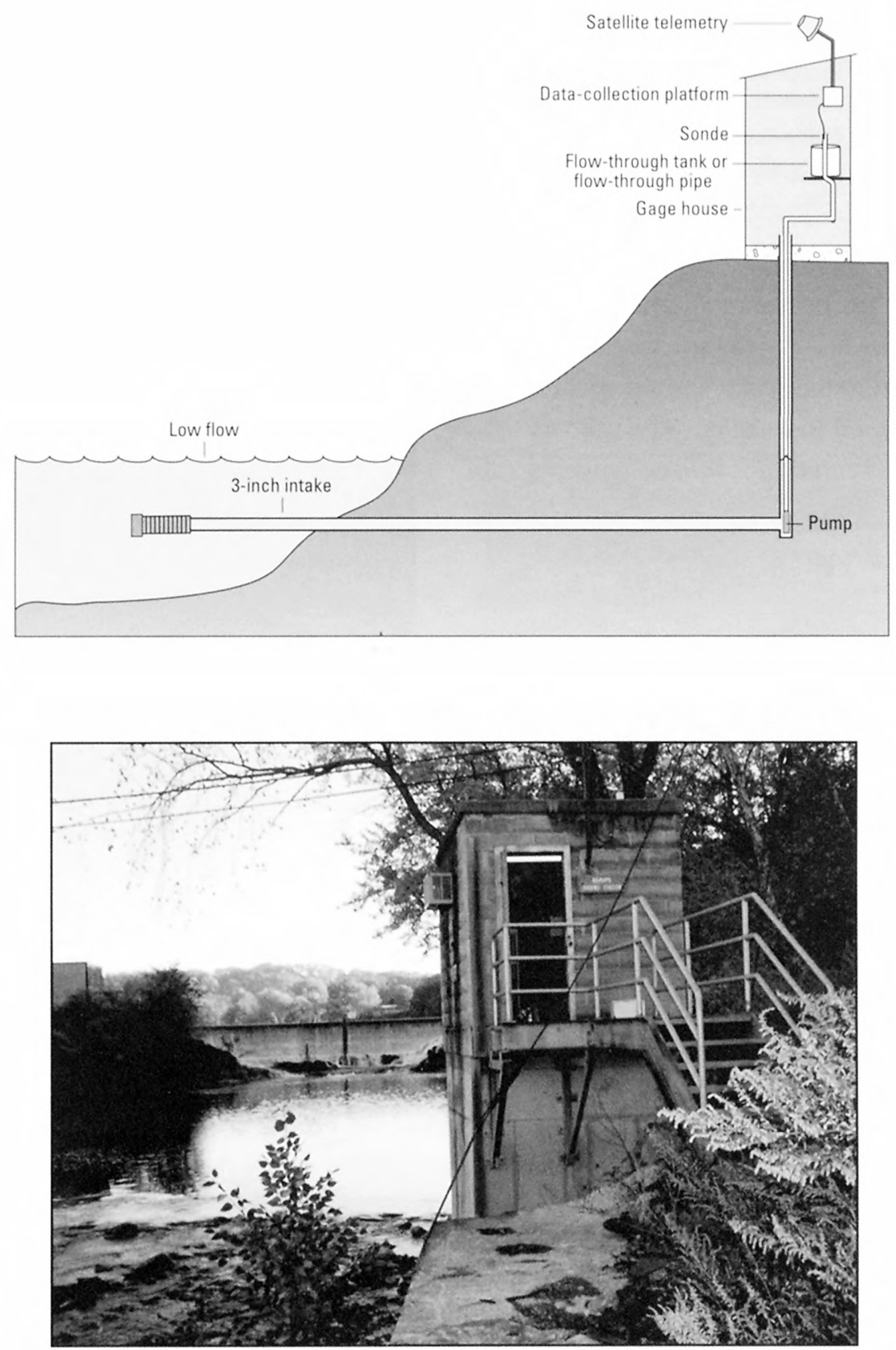

Figure 1. Flow-through water-quality monitoring station. (PHOTOGRAPH: RAMAPO River at Pompton Lakes, NeW Jersey, by Michael J. Deluca) 
Table 1. Principal advantages and disadvantages of flowthrough monitoring systems

\begin{tabular}{|c|c|}
\hline Advantages & Disadvantages \\
\hline $\begin{array}{l}\text { Unit can be coupled with } \\
\text { chlorinators to reduce } \\
\text { membrane fouling. }\end{array}$ & 120-volt AC power source is needed. \\
\hline $\begin{array}{l}\text { Expensive sensor systems } \\
\text { can be secured in } \\
\text { vandal-proof shelters. }\end{array}$ & Higher installation costs are incurred. \\
\hline $\begin{array}{l}\text { Calibration can be per- } \\
\text { formed in the shelter. }\end{array}$ & $\begin{array}{l}\text { Pumps tend to clog in streams with } \\
\text { algal fouling or high sediment } \\
\text { loads. } \\
\text { Electrical shock protection is } \\
\text { required. } \\
\text { Pumps may be damaged by corrosive } \\
\text { waters. } \\
\text { Pump maintenance is required. } \\
\text { Pumping may cause changes in water } \\
\text { quality. }\end{array}$ \\
\hline
\end{tabular}

The sensors in the in-situ monitoring system are placed at the measuring point in the stream cross section (fig. 2). Cables run from the sensors to the recording equipment that is housed in a shelter. The primary advantage of this configuration is that no power is needed to pump water (table 2). Direct current, 12-volt batteries easily meet the power requirements of the sensors and recording equipment. In-situ water-quality monitoring systems can be installed at remote locations where AC power is not available, but the advantages and disadvantages of the in-situ monitoring system also must be considered.

Table 2. Principal advantages and disadvantages of in-situ monitoring systems.

\begin{tabular}{|c|c|}
\hline \multicolumn{1}{|c|}{ Advantages } & \multicolumn{1}{c|}{ Disadvantages } \\
\hline $\begin{array}{c}\text { No power is needed to } \\
\text { pump water. }\end{array}$ & Sensors are susceptible to vandalism. \\
$\begin{array}{c}\text { Remote locations are } \\
\text { possible. } \\
\begin{array}{c}\text { Smaller shelters can be } \\
\text { used. }\end{array}\end{array}$ & $\begin{array}{c}\text { The water flow cannot be treated to } \\
\text { reduce fouling. }\end{array}$ \\
$\begin{array}{c}\text { In shallow bank installations, the } \\
\text { proper location of sensors in the } \\
\text { cross section is difficult. }\end{array}$ \\
$\begin{array}{c}\text { Freeze protection is } \\
\text { provided to the sensors. }\end{array}$ \\
$\begin{array}{c}\text { Electrical hazards are } \\
\text { reduced. }\end{array}$ & $\begin{array}{c}\text { Sensors are susceptible to debris or } \\
\text { high flow. }\end{array}$ \\
\hline
\end{tabular}
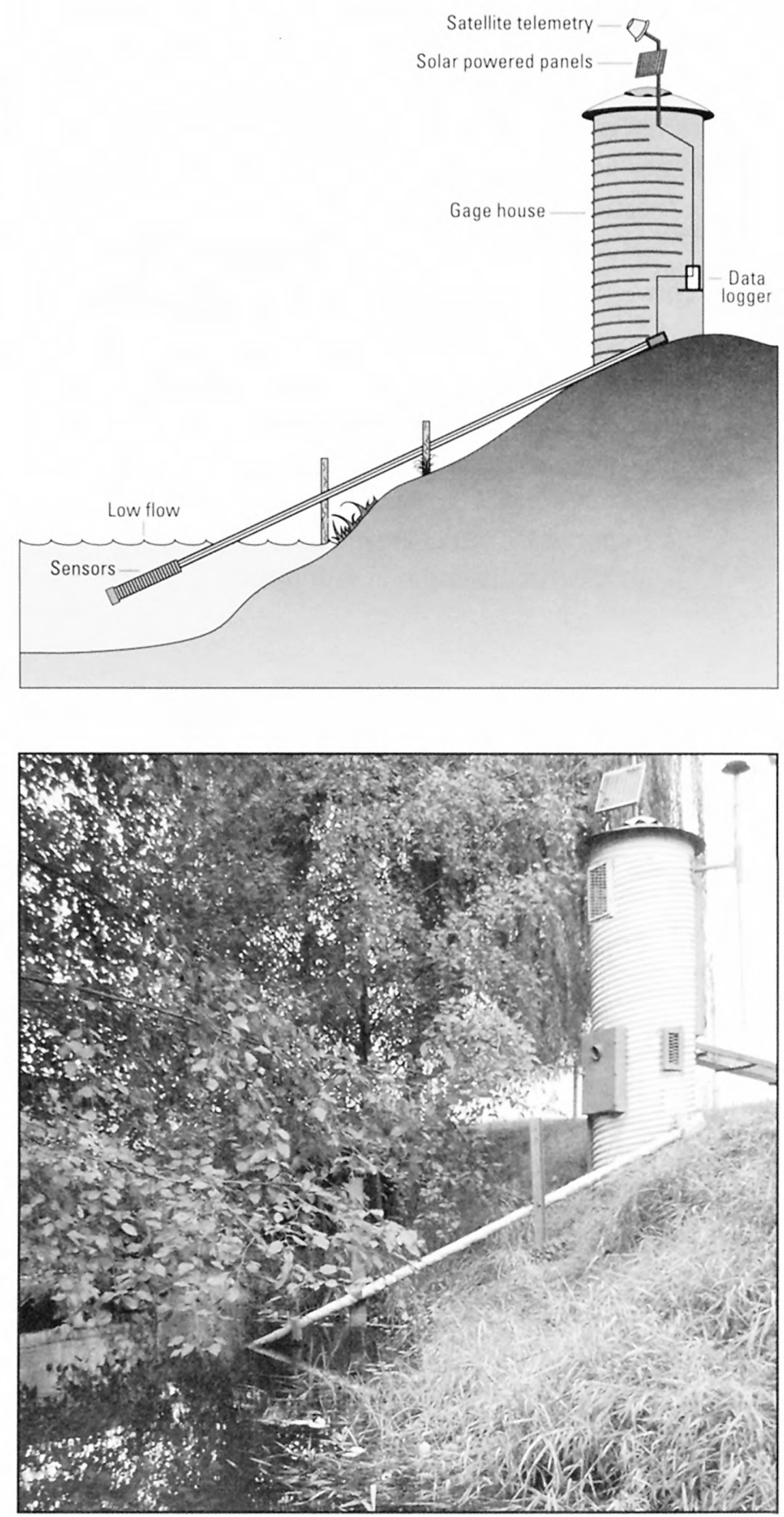

Figure 2. In-situ water-quality monitoring station.

(Photograph: SPRing Brook CREEK at Orillia, WASHington, BY DAVID K. MULLIS) 
The third water-quality monitoring system is a combined sensor and recording sonde that is self contained, requires no external power, and reduces exposure to vandalism. Power is supplied by conventional batteries located in a sealed compartment, and sensor data are stored within the sonde on nonvolatile, flash-memory, recording devices (fig. 3). The advantages and disadvantages of the self-contained sensor and recording system must be considered (table 3 ).

Table 3. Principal advantages and disadvantages of the self-contained monitoring system.

\begin{tabular}{|c|c|}
\hline Advantages & Disadvantages \\
\hline $\begin{array}{l}\text { Location options are } \\
\text { flexible. }\end{array}$ & $\begin{array}{l}\text { Data are available only during site } \\
\text { visits. }\end{array}$ \\
\hline $\begin{array}{l}\text { The monitor is protected } \\
\text { from vandalism. }\end{array}$ & $\begin{array}{l}\text { Equipment status checks are } \\
\text { required. }\end{array}$ \\
\hline \multirow[t]{5}{*}{$\begin{array}{l}\text { Electrical hazards are } \\
\text { nonexistent. }\end{array}$} & $\begin{array}{l}\text { Servicing sensors and recovering } \\
\text { data can be difficult. }\end{array}$ \\
\hline & $\begin{array}{l}\text { Sensors are susceptible to debris or } \\
\text { high flow. }\end{array}$ \\
\hline & $\begin{array}{l}\text { Shifting channels may cause } \\
\text { movement of the equipment. }\end{array}$ \\
\hline & $\begin{array}{l}\text { Status of the equipment can be } \\
\text { checked only while servicing. }\end{array}$ \\
\hline & If batteries die, data are lost. \\
\hline
\end{tabular}

\section{Types of Sensors}

Sensors are available for continuous

measurement of many physical properties and chemical constituents, but five of the most commonly used sensors are for the measurement of temperature, specific conductance, DO, pH, and turbidity.

\section{Temperature}

Temperature has an important influence on the density of water, the solubility of constituents in water, $\mathrm{pH}$, specific conductance, the rate of chemical reactions, and biological activity in water (Radtke, Kurklin, and Wilde, 1998). The preferred watertemperature scale for most scientific work is the Celsius scale. Continuous water-quality sensors usually measure temperature with a thermistor, which is a semiconductor with resistance that changes with temperature. Thermistors are reliable, accurate, and durable sensors that require little maintenance and are relatively inexpensive. Modern thermistors can easily measure temperature to plus or minus $( \pm) 0.1$ degree
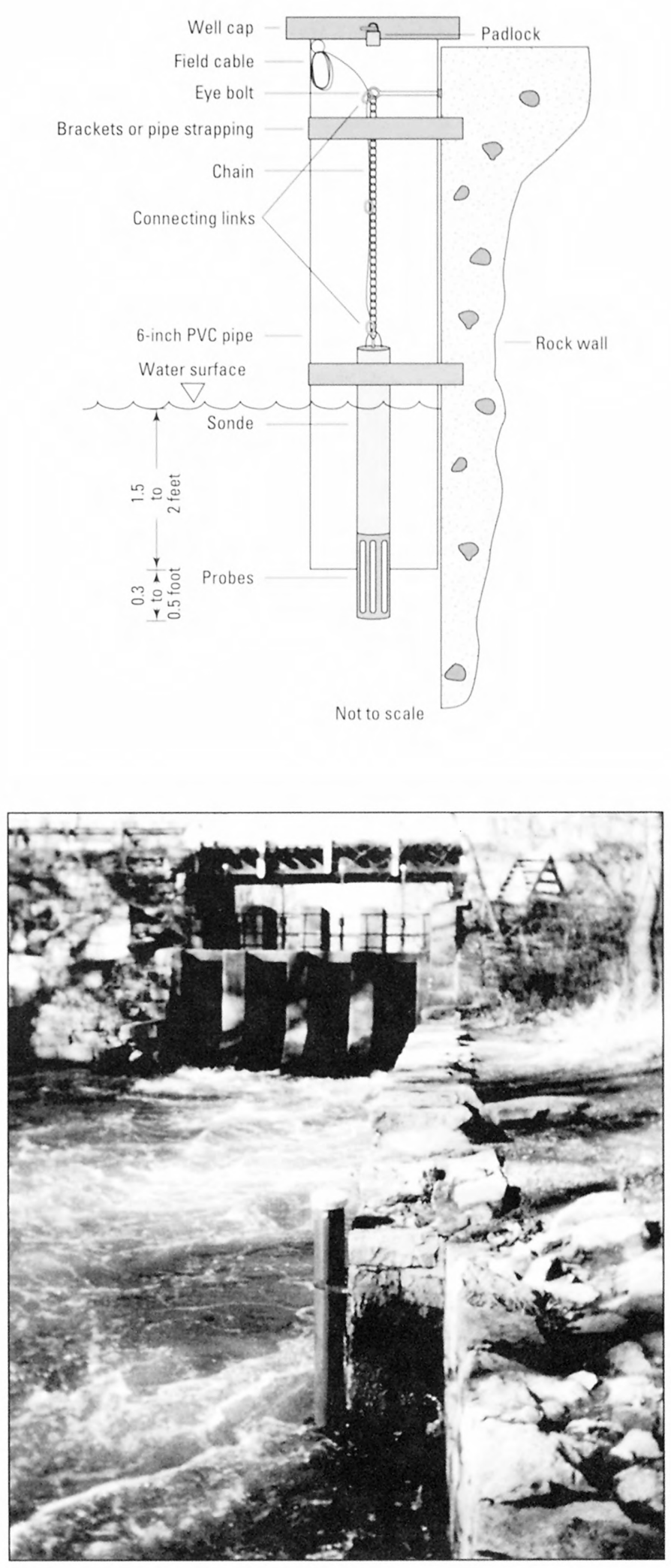

Figure 3. Self-contained water-quality monitoring sensor and recording system. (PHOTOGRAPH: DELAWARE AND RARITAN CANAL FEeder at RAVEN RoCK, NEW JERSEY, by BONNIE GRAY) 
Celsius $\left({ }^{\circ} \mathrm{C}\right)$, but the user must verify the accuracy claimed by the manufacturer for the range of application. Typically, temperatures are reported to the nearest $0.5{ }^{\circ} \mathrm{C}$ because the thermistor is located at one point, which may not be representative of the entire body of water being measured.

\section{Specific Conductance}

Specific conductance is a measure of the capacity of water to conduct an electrical current and is a function of the types and quantities of dissolved substances in water (Radtke, Davis, and Wilde, 1998). As concentrations of dissolved ions increase, specific conductance of the water increases. Specific conductance measurements are a good indication of total dissolved solids and total ion concentrations, but there is no universal linear relation between total dissolved solids and specific conductance. A continuous record of specific conductance can be used in conjunction with chemical analyses and continuous discharge records to estimate constituent loads (Clifton and Gilliom, 1989; Hill and Gilliom, 1993; Christensen and others, 2000). The USGS measures specific conductance at or compensated to $25^{\circ} \mathrm{C}$ and reports specific conductance in microsiemens per centimeter at $25{ }^{\circ} \mathrm{C}\left(\mu \mathrm{S} / \mathrm{cm}\right.$ at $\left.25^{\circ} \mathrm{C}\right)$.

Specific conductance sensors are one of two types - contact sensors with electrodes and sensors without electrodes. Continuous water-quality sensors generally have electrodes that require the user to choose a cell constant for the expected range of specific conductance. Multiparameter monitoring systems usually contain automatic temperature compensation circuits; thus, specific conductance usually is compensated to $25^{\circ} \mathrm{C}$, but this should be verified by checking the manufacturer's instruction manual. All modern monitoring systems are designed for medium-strength specific conductance waters ( 100 to $2,000 \mu \mathrm{S} / \mathrm{cm}$ at $25^{\circ} \mathrm{C}$ ) or higher. In general, specific conductance electrodes are reliable, accurate, and durable but are susceptible to fouling from aquatic organisms and sediment.

\section{Dissolved Oxygen}

The DO concentration in surface water is related primarily to atmospheric reaeration and photosynthetic activity of aquatic plants (Radtke, White, and others. 1998). The range of observed DO in surface waters typically is from 2 to 10 milligrams per liter ( $\mathrm{mg} / \mathrm{L}$ ) at
$20{ }^{\circ} \mathrm{C}$. The value for 100 -percent saturation of DO decreases with increased temperature and increases with increased atmospheric pressure. Occasions of excess oxygen (supersaturation) often are related to extreme photosynthetic production of oxygen by aquatic plants as a result of nutrient (nitrogen and phosphorus) enrichment, sunlight, and low-flow conditions. Occasions of saturated oxygen commonly are related to cascading flow conditions, both natural and artificial. DO may be depleted by inorganic oxidation reactions or by biological and chemical processes that consume dissolved, suspended, or precipitated organic matter (Hem, 1989). DO is a significant factor in chemical reactions in water and the survival of aquatic organisms.

The most commonly used technique for measuring DO concentrations with continuous waterquality sensors is the amperometric method, which measures DO with a temperature-compensated polarographic membrane-type sensor. While polarographic membrane-type sensors generally provide accurate results, they commonly are sensitive to temperature and water velocity and are prone to fouling. Because the permeability of the membrane and solubility of oxygen in water change as functions of temperature, it is critical that the DO sensors be temperature compensated.

The measuring process consumes DO; therefore, water flow past the sensor is critical. If water velocity at the point of measurement is less than 1 foot per second $(\mathrm{ft} / \mathrm{s})$, an automatic or manual stirring mechanism or a different measurement technique is required. DO sensors are prone to inaccuracies from algal fouling, sedimentation, low velocity, and very high velocities. A complete discussion of DO calibration, measurement, and limitations can be found in Radtke, White, and others (1998).

$\mathrm{pH}$

The $\mathrm{pH}$ of an aqueous solution is controlled by interrelated chemical reactions that produce or consume hydrogen ions (Hem, 1989). The $\mathrm{pH}$ of a solution is a measure of the effective hydrogen-ion concentration (activity; Radtke, Busenberg, and others, 1998). More specifically, $\mathrm{pH}$ is a measure that represents the negative base-10 logarithm of hydrogenion activity of a solution, in moles per liter. Solutions having a pH below 7 are described as acidic; solutions with a pH greater than 7 are described as basic or 
alkaline. Dissolved gases, such as carbon dioxide, hydrogen sulfide, and ammonia, appreciably affect $\mathrm{pH}$. Degasification (for example, loss of carbon dioxide) or precipitation of a solid phase (for example, calcium carbonate) and other chemical, physical, and biological reactions may cause the $\mathrm{pH}$ of a water sample to change appreciably soon after sample collection (Radtke, Busenberg, and others, 1998).

The electrometric $\mathrm{pH}$ measurement method, using a hydrogen-ion electrode, commonly is used for continuous water-quality $\mathrm{pH}$ sensors. Sensors used in submersible monitors typically are combination electrodes in which a proton $(\mathrm{H}+)$-selective glass-bulb reservoir is filled with an approximate $\mathrm{pH}-7$ buffer. A silver wire coated with silver chloride is immersed in the internal reference electrode buffer reservoir. Protons on both sides of the glass $\mathrm{pH}$ electrode (media and buffer reservoir) selectively interact with the glass, setting up an external potential gradient across the outer glass membrane. Because the hydrogen-ion concentration in the internal buffer solution is constant, this external potential difference across the outer glass membrane, which is determined relative to the internal silver/silver-chloride reference electrode, is proportional to the $\mathrm{pH}$ of the medium. A correctly calibrated $\mathrm{pH}$ sensor can accurately measure $\mathrm{pH}$ to $\pm 0.2 \mathrm{pH}$ unit; however, the sensor can be scratched, broken, or fouled easily. Detailed instructions for the calibration and measurement of $\mathrm{pH}$ are described by Radtke, Busenberg, and others (1998) or by the instrument manufacturer.

\section{Turbidity}

Turbidity sensors operate differently from those for temperature, specific conductance, $\mathrm{DO}$, and $\mathrm{pH}$, which convert electrical potentials into the measurement of the constituent of interest. A turbidity sensor operates by directing a light beam from a light-emitting diode into the water sample and measuring the light that scatters off the suspended particles present in the water. The nephelometric measurement method is used in most commercially available sensors with a sensor range of $0-1,000$ nephelometric turbidity units (NTU) and an accuracy of \pm 5 percent or $2 \mathrm{NTU}$, whichever is greater. However, some sensors can report values reliably up to about 1,500 NTU.

Turbidity readings are affected by suspendedsediment particle size, entrained air bubbles, floating debris, and other particles in the water that may collect on or near the optic sensor during data collection. The effect of temperature on turbidity sensors is minimal, and the software for modern sensors provides temperature compensation. Calibration and measurement of turbidity by using a submersible sensor are discussed by Wilde and Gibs (1998), but manufacturer's instructions and recommendations must be followed. Sensors that are maintained and calibrated routinely will be relatively error free and will provide valid data at all times.

\section{Instrument Acceptance Criteria}

Independent testing to ensure accuracy and reliability is an important part of any quality-assurance program for hydrologic field instrumentation. As stated in the Water-Resources Division (WRD) Hydrologic Field Instrumentation and Equipment Policy and Guidelines (U.S. Geological Survey WRD Memorandum 95-35, 1995), any USGS District, program, or project that procures an instrument is responsible for ensuring that adequate testing is carried out and that the documented results fully characterize the performance and capabilities of the instrument. One of the primary responsibilities of the USGS Hydrologic Instrumentation Facility (HIF) is the testing, evaluation, and documentation of instrument performance. Districts are encouraged to purchase instruments through the HIF when possible or perform the necessary steps of independent testing to ensure accuracy and reliability as stated by the instrument manufacturer. District personnel are encouraged to work with the HIF to evaluate new instrumentation and actively participate in the web-based instrument quality-assurance data base managed by the HIF by entering, reviewing, and overseeing District data in the data base and by taking corrective actions when necessary.

\section{Site Selection}

The location of a water-quality monitoring site is directly related to the purpose of monitoring and the data-quality objectives. Stream characteristics, location of the site, and other data-quality objectives determine whether a data sonde will be placed in situ or whether a flow-through receptacle with a pumping sampler will be a better choice. More site-specific considerations in monitor placement include sitedesign considerations, monitor installation, physical constraints, and service requirements (table 4). 
Table 4. Factors for consideration in the placement and installation of continuous water-quality monitoring systems

\begin{tabular}{|c|}
\hline Site-design considerations \\
\hline Representative of cross-sectional variability \\
\hline Constraints of channel configuration \\
\hline Range of streamflow (from low flow to flood) \\
\hline Velocity of streamflow \\
\hline Turbulence \\
\hline Avoidance of high-water debris damage \\
\hline Range of values for water-quality physical properties \\
\hline Protection from vandalism \\
\hline Safety hazards \\
\hline Monitor installation \\
\hline Permits for installation \\
\hline Type of installation \\
\hline Difficulty and cost of installation \\
\hline Ability to install monitor in representative location \\
\hline Logistics (service requirements) \\
\hline Accessibility of site \\
\hline Frequency of service interval to meet data-quality objectives \\
\hline Rate of fouling \\
\hline Proximity to cross-section measuring location \\
\hline Event related (for example, flooding event) \\
\hline Proximity to electrical power or telephone service \\
\hline Need for real-time reporting \\
\hline
\end{tabular}

Balancing the numerous site considerations for placement of a continuous water-quality monitoring system is difficult. The optimum site consideration for achieving the data-quality objectives is placing the pump intake, sensor package, or sonde in a location that best represents the section of the water body being measured. Lateral mixing in large rivers, however, often is not complete for tens of miles downstream from a tributary or outfall. A location near the streambank may be more representative of local runoff or affected by point-source discharges upstream, whereas a location in center channel may be more representative of areas farther upstream in the drainage basin.

Turbulent streamflow may aid in mixing, but turbulence can create problems for some monitored parameters such as DO or turbidity. For a medium to small stream with alternating pools and riffles, the best flow and mixing occurs in the riffle portion of the stream; however, flooding may change the locations of shoals upstream from the monitoring site, and the measurement point may no longer represent the overall water-quality characteristics of the water body.
Sufficient cross-section measurements must be made at the site to determine if a prospective site is sufficiently well mixed and to ensure that the site will not be subject to significant difference in a cross section. If significant horizontal or vertical variability is determined, consideration must be given to choosing another site or using a different approach to meet the data-quality objectives (see Placement of Sensors in the Cross Section).

Large streams and rivers may be monitored best from the downstream side of bridge abutments, assuming that safety hazards and other difficulties can be reduced or overcome. The measurement point in the vertical dimension for larger flow systems also needs to be appropriate for the primary purpose of the monitoring installation. The vertical measurement point can be chosen for low-, medium-, or high-flow conditions.

Selection of a water-quality monitoring site is determined by the data-quality objectives, and the best location for a site is often one that is best for measuring surface-water discharge. Although hydraulic factors in site location must be considered, it is more important to consider factors that affect the water-quality data. It is important to select a site that is representative of the stream, and the cross-section characteristics of specific conductance, turbidity, or pH may be helpful in selecting the best sites. Assessment of a site may be dependent on fouling potential, high-tension power lines, or radio towers that may interfere with data collection or telemetry. The same hydraulic factors that are used in selecting a specific site for gaging discharge in a channel also can be used in selecting a waterquality monitoring location. Both purposes seek a representative site that approaches uniform conditions across the entire width of the stream. Rantz and others (1982) identified nine hydraulic conditions of the ideal gage site, and these also must be considered in site selection for water-quality sites (table 5).

The location of water-quality monitoring sensors in cold regions requires additional considerations in order to obtain data during periods of ice formation. White (1999) discusses environmental factors in the site selection of an automated waterquality station in British Columbia, Canada, but also generalizes morphological stream factors and the importance of selecting a site that has a minimal chance of damage or destruction from natural forces and a minimal source of bubbles. White also 
Table 5. Hydraulic conditions of the ideal gage site (after Rantz and others, 1982)

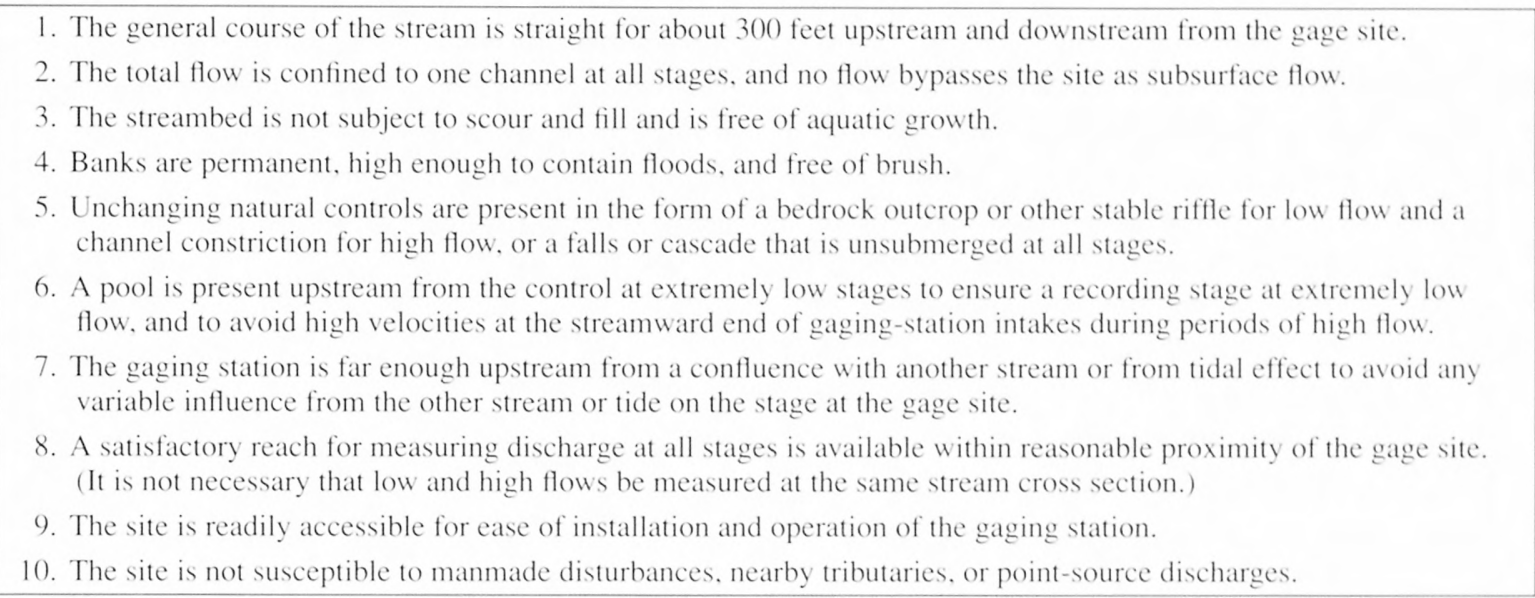

emphasizes that a site should (1) meet minimum stream-depth requirements for instruments, (2) be safe and accessible under all conditions, and (3) be located to avoid the danger of vandalism.

\section{Placement of Sensors in the Cross Section}

The location of a water-quality monitoring site is dependent on the purpose of monitoring and the data-. quality objectives. In some cases, such as the location of a monitoring site in a lake, bay, or estuary, the data-quality objectives may require only point measurements; whereas, data-quality objectives for the measurement of load or flux in a large river generally require placement of a water-quality monitoring site at the most representative measurement point in the cross section of the stream.

Determinations of cross-sectional variability are required before a monitoring site is installed to properly locate the most representative measurement point in the stream cross section and to determine if a cross-section correction is necessary. A minimum of two cross-section measurements per year is required to verify that no significant changes have occurred in the distribution of constituents across the stream.

Documentation of vertical mixing is required at least annually at a minimum of two depths for all crosssection measurements. For monitoring sites that are operated more than 1 year, a minimum of six crosssection measurements representing different flow conditions is required to determine if discharge or seasonal changes are affecting significantly the distribution of constituent values in the cross section. By choosing a monitoring site with well-mixed streamflow, cross-section corrections may not be needed.

Standard USGS procedure is to use either discharge- or area-weighted methods for selecting locations of the most representative measurement points in a cross section to ensure that chemical loads can be calculated correctly (Wilde and Radtke, 1998). The measurement point in a cross section is established by using either method to obtain data by using calibrated field instruments. Generally, a minimum of five increments across a large stream or river is sufficient to provide a discharge-weighted mean and establish the horizontal cross-sectional variability of the measured physical property. Alternatively, an areaweighted value can be determined by measuring the centroid of equal-width increments with calibrated field instruments. Generally, a minimum of 10 and a maximum of 20 measurement points across a large stream or river is sufficient to establish the horizontal cross-sectional variability of a physical property. Computations of mean physical property values for a large number of cells will produce a cross-section correction for any measurement location with good flow; however, as the number of cells exceed 40 or more, the computational precision exceeds the measuring precision. Examples of both area- and discharge-weighted field measurements are demonstrated by Wilde and Radtke (1998). 
The number of vertical measurements needed for deeper flow regimes is dependent on the degree of vertical mixing. If physical or chemical stratification is observed, the number of vertical measurements may need to be increased from mid-depth to two measurements ( 0.2 and 0.8 depth) or more. The vertical stratification may be sharply defined, which requires the measurements across the transition zone to be more closely spaced to represent the position and degree of stratification adequately.

The most efficient means of obtaining physical property multiparameter measurements is with a multisensor monitor that can measure more than one physical property at each measurement point. For locations with higher stream velocities, point sampling with a heavy sampler may be necessary. Measurements of discrete samples from the cross section should be made quickly before measurable changes occur in some physical properties. Discrete samples should not be composited for measurement of cross-section corrections.

In the case of $\mathrm{pH}$, a median value is used for determining the measuring-point correction.

Alternatively, $\mathrm{pH}$ values can be converted to hydrogenion concentrations (antilogarithms of negative $\mathrm{pH}$ ) for computational purposes (see Appendix 1). Computed mean $\mathrm{pH}$ values tend to be more acidic than median values; for large flow systems with 40 or more $\mathrm{pH}$ measurements, the median and the properly computed mean $\mathrm{pH}$ values should be very close.

Specific information about a field site (station) is summarized in a station description (see Appendix 2). The station description, which contains specific information about a field site location, history, and operation, should be placed in an appropriate field folder and carried into the field. Cross-section measurements and extreme values must be updated annually in the station analysis (see Appendix 3) as part of the data-evaluation process. For many stations with critical data-quality objectives, service intervals may be a week or less. The service interval must be included in the station description as well as in the report manuscript station description, as described by Novak (1985).

\section{Field Meter Calibration}

Measurements that compare field meter physical property values with the continuous monitor readings should be made before, during, and after servicing the monitor to document any environmental changes during the service interval. Measurements are made at the monitoring site by using calibrated field instruments as close to the sensor as possible and within 5-minute intervals. Before site visits, all support field meters should be checked for operation and accuracy. Minimum calibration frequency is detailed by Wilde and Radtke (1998) for each type of meter, and all calibrations are recorded in the corresponding instrument log books. All information related to preand post-trip, National Field Quality Assurance, and other periodic calibrations is recorded in the instrument log books.

\section{Temperature}

The proper calibration and documentation for thermometers and thermistor thermometers are detailed by Radtke, Kurklin, and Wilde (1998). The USGS procedures specify that thermometers be calibrated or checked against a National Institute of Standards and Technology (NIST)-certified thermometer, and thermistors should be accurate within $\pm 0.2^{\circ} \mathrm{C}$. For both thermistors and liquid-inglass thermometers, an annual 5 -point calibration over the temperature range of $0-40{ }^{\circ} \mathrm{C}$ is required. The annual 5-point check requires laboratory equipment. In addition, 2-point calibration checks over the maximum and minimum expected annual temperature range should be made three or more times per year for thermistors and two or more times per year for liquidin-glass thermometers. Calibrated thermometers and thermistors must be marked with the date of calibration.

\section{Specific Conductance}

The proper calibration and documentation for specific conductance meters are detailed by Radtke, Davis, and Wilde (1998). Standards bracketing the expected full range of anticipated values are used to calibrate the specific conductance meter to the appropriate units for particular field conditions. Calibration is performed at the field site with standards that have been allowed to equilibrate to the temperature of the water being monitored. The accuracy of the meter should be within 5 percent for specific conductance values less than or equal to $100 \mu \mathrm{S} / \mathrm{cm}$, or within 3 percent for specific conductance values more than $100 \mu \mathrm{S} / \mathrm{cm}$. Specific conductance standards are 
available from the USGS Ocala Quality Water Service Unit (QWSU). Standards must be discarded after use.

\section{Dissolved Oxygen}

The proper calibration and documentation for DO meters are detailed by Radtke, White, and others (1998). DO sensors measure the partial pressure of DO by the flow of oxygen through a porous membrane and oxygen consumption at a cathode. The calibrated accuracy of DO meters should be within the lesser of 5 percent or $\pm 0.3 \mathrm{mg} / \mathrm{L}$. The accuracy of a DO meter at $0.0 \mathrm{mg} / \mathrm{L}$ is verified by measuring the DO of a sodium sulfite solution, as described by Radtke, White, and others (1998). Calibration of a DO meter at 100percent oxygen saturation is made by adjusting the meter reading for air saturated with water vapor to a value obtained from a solubility table generated from the equations of Weiss (1970) and listed in Radtke, White, and others (1998). The 100-percent saturation value is based on the water temperature and the uncorrected barometric pressure. A reliable pocket altimeter can be used to measure uncorrected (true) atmospheric pressure to the nearest 1 millimeter ( $\mathrm{mm}$ ) of mercury. An additional correction for salinity, based on temperature and specific conductance, should be calculated for waters that have specific conductance values greater than $2,000 \mu \mathrm{S} / \mathrm{cm}$. Calibration and operation procedures differ among instrument types . and makes, and manufacturer's instructions must be followed closely. All calibration information must be recorded in the instrument log book.

\section{$\mathrm{pH}$}

A detailed 10-step description of the calibration of $\mathrm{pH}$ meters and that covers a wide range of available equipment is described by Radtke, Busenberg, and others (1998). Calibration and adjustments for multiparameter sensor systems are found in the manufacturer's service manuals. Accuracy of field $\mathrm{pH}$ meters should be at least $\pm 0.1 \mathrm{pH}$ unit. Two standard buffers bracketing the expected range of environmental values are used to calibrate a pH electrode, and a third is used as a check for linearity. The pH-7 buffer is used to establish the null point, and a $\mathrm{pH}-4$ or $\mathrm{pH}-10$ buffer is used to establish the slope of the calibration line at the temperature of the solution. The slope of a $\mathrm{pH}$ electrode is temperature sensitive, but modern sensors can adjust the $\mathrm{pH}$ slope to the observed temperatures through manual or automatic temperature compensation. It is important, however, that the temperatures of the buffers be as close as possible to the samples being measured. Immersing the $\mathrm{pH}$ buffer bottles in the surface water for about 15 minutes allows the stream or river temperature and the buffer temperature to equilibrate. Standard buffers of $\mathrm{pH} 4,7$. and 10 are readily available from the QWSU. All calibration information is to be recorded in the instrument $\log$ and on the field notes. Proper calibration of $\mathrm{pH}$ sensors for low specific conductance waters, less than $100 \mu \mathrm{S} / \mathrm{cm}$, is described by Busenberg and Plummer (1987) and by Radtke, Busenberg, and others (1998).

\section{Turbidity}

The proper calibration and documentation for turbidity meters are described by Wilde and Gibs (1998). Calibration of a turbidity instrument by using Formazin or another primary standard usually is done in the laboratory, with instrument checks being performed in the field. Most sensor manufacturers recommend either Formazin or other approved primary standards, such as styrene divinylbenzene (SDVB) polymer standards, for calibrating turbidity sensors. Formazin-based standards can be diluted by using a dilution formula; however, errors may be introduced during the dilution process, thus reducing the accuracy of the standard solution. Formazin-based standards also are temperature dependent, and accurate readings may be difficult to obtain during field conditions. Wilde and Gibs (1998) suggest that the effect of thermal fluctuations can be minimized by calibrating the instrument at room temperature in an office laboratory using a Formazin-based standard and secondary standard. Instrument calibration can then be checked at the field site by using a secondary standard. Turbidity standards for various ranges are available commercially. Before placing the sensor in a standard, the sensor must be cleaned, rinsed three times with turbidity-free water, and carefully dried. Turbidity-free water is prepared as described by Wilde and Gibs (1998).

\section{Monitor Operation}

The operation of a water-quality monitoring station is intended to produce the greatest amount of correctable field record that can be verified. The general operational categories include maintenance of 
the station and equipment; inspection and recording of sensor readings; cleaning, calibration, and troubleshooting of sensors and recording equipment; crosssection measurements; and accurate record keeping.

\section{Maintenance}

Maintenance frequency generally is governed by the fouling rate of the sensors, and this rate varies by sensor type, hydrologic environment, and season. The performance of temperature and specific conductance sensors tends to be less affected by fouling, whereas the dissolved oxygen, $\mathrm{pH}$, and turbidity sensors are more prone to fouling. The use of wiper or shutter mechanisms on modern turbidity instruments has decreased the fouling problem significantly. For stations with critical data-quality objectives, service intervals may be weekly or more often. Monitoring sites with nutrient-enriched waters and moderate to high temperatures may require service intervals as frequently as every third day. In cases of severe environmental fouling or remote locations, the use of an observer for servicing the water-quality monitor should be considered. In addition to fouling problems. physical disruptions (such as pump failure, recording equipment malfunction, sedimentation, electrical disruption, debris, ice, or vandalism) also may require additional site visits. The service needs of waterquality monitoring stations equipped with telemetry can be recognized quickly, and the use of satellite telemetry to verify proper equipment operation is recommended.

The general maintenance functions at a waterquality monitoring station include:

- Daily review of sensor function for sites equipped with telemetry

- Inspection of the site for signs of physical disruption

- Inspection of sensor(s) for fouling, corrosion, or damage

- Battery (or power) check

- Time check

- Routine sensor cleaning and servicing

- Calibration (if needed)

- Downloading of data

The specific maintenance requirements depend on the site configuration and equipment. A useful discussion of the maintenance requirements for the flow-through and USGS minimonitor installations can be found in Gordon and Katzenbach (1983), but nearly all operational requirements are fulfilled by the completion of a water-quality continuous monitor field-inspection form (Appendix 4). The manufacturer's instructions must be followed for other types of equipment.

\section{Sensor Inspection}

The purposes of the sensor inspection are to provide an ending point for the interval of waterquality record since the last service visit, a beginning point for the next interval of water-quality record, and verification that the sensor is working properly. This is accomplished by recording the initial sensor readings, servicing the sensors, recording the cleaned sensor readings, performing a calibration check of sensors by using appropriate standards, and if the readings of the monitoring sensor are outside the range of acceptable differences (see next section, Monitor Calibration Criteria), recalibrating the sensor. A final environmental sensor reading is required after the calibration check or after recalibration. The difference between the initial sensor reading and the cleaned sensor reading is the sensor error as a result of fouling; the difference between the calibration-check reading and calibrated-sensor reading, if necessary, is a result of drift. All information related to the sensor inspection must be recorded on a field form or in a field notebook. The sensor readings in the field notes become the basis for corrections (shifts) during the record-processing stage; thus, a complete and thorough documentation of the sensor inspection is important.

The initial sensor readings (before cleaning) of the monitoring equipment are compared to a calibrated field meter before removing the monitor sonde for servicing. The comparison ideally is made at the measuring point in the stream. This initial sensor reading becomes the ending point of the data record since the last servicing, and the field meter reading provides a sense of the reasonableness of the monitor readings and an indication of potential drift and fouling. However, except for temperature sensors, the field meter readings are not used directly in record computation. The field meter is used as a tool to assess cross-sectional variability and environmental changes that may occur while the monitor is being serviced.

Upon removal from the water, the monitoring sensors are inspected for signs of chemical precipitates, stains, siltation, or aquatic growth. These observations are recorded in the field notes before cleaning, and the 
individual sensors must be cleaned according to the manufacturer's specifications. The cleaned sonde or sensor is then returned to the stream and checked against the field meter. Both instrument readings are recorded in the field notes. The observed difference between the initial sensor reading and the cleaned sensor reading is a result of fouling (chemical precipitates, stains, siltation, or aquatic growth).

\section{Monitor Calibration Criteria}

The concept of not calibrating sensors for small changes from a standardized value was defined by Gordon and Katzenbach (1983). This idea recognizes limits in recording electronic data under field conditions that are close to the operating accuracy of the equipment. Adjustments within these acceptable limits may not improve the overall data accuracy. With improvements in sensor technology, this acceptablelimit concept has been refined to calibration criteria for recording field sensors based on the stabilization criteria defined by Wilde and Radtke (1998) and also takes into consideration the lesser accuracy of some continuous water-quality sensors. A calibration check using known standards is performed on cleaned monitoring sensors; if the monitor sensors are outside the range of acceptable differences, the sensor must be recalibrated. If the calibration-check sensor readings for the monitor are within the calibration criteria (table 6), the monitoring sensors are considered checked and no further adjustments are required.

Table 6. Calibration criteria for continuous water-quality monitors

1.. plus or minus value shown; ${ }^{\circ} \mathrm{C}$, degree Celsius: $\mu \mathrm{S} / \mathrm{cm}$, microsiemens per centimeter at $25^{\circ} \mathrm{C}$; mg/L, milligram per liter; $\mathrm{pH}$ unit, standard $\mathrm{pH}$ unit: NTU, nephelometric turbidity unit ]

\begin{tabular}{|l|l|}
\hline \multicolumn{1}{|c|}{$\begin{array}{c}\text { Measured physical } \\
\text { property }\end{array}$} & \multicolumn{1}{c|}{$\begin{array}{c}\text { Calibration criteria for measurements } \\
\text { (variability should be within } \\
\text { the value shown) }\end{array}$} \\
\hline \hline $\begin{array}{l}\text { Temperature } \\
\text { Specific conductance }\end{array}$ & $\begin{array}{c} \pm 0.2^{\circ} \mathrm{C} \\
\text { The greater of } \pm 5 \mu \mathrm{S} / \mathrm{cm} \text { or } \pm 3 \text { percent } \\
\text { of the measured value } \\
\pm 0.3 \mathrm{mg} / \mathrm{L}\end{array}$ \\
$\begin{array}{l}\text { Dissolved oxygen } \\
\text { pH } \\
\text { Turbidity }\end{array}$ & $\begin{array}{l}\text { The greater of } \pm 2 \text { NTU or } \pm 5 \text { percent } \\
\text { of the measured value }\end{array}$ \\
\hline
\end{tabular}

All sensor readings are recorded in the field notes, and all calibration information is recorded in the monitor instrument log. The calibrated monitoring sensor is returned to the stream and allowed to equilibrate to the stream temperature. The observed difference between the cleaned sensor calibrationcheck reading and the calibrated sensor reading (if necessary) is a result of drift. The calibrated sensor stream reading is the beginning observation of the new water-quality record interval. If the calibrated monitoring sensor fails to agree with the calibrated field meter within the calibration criteria, the faulty sensor must be repaired or replaced after verifying that the readings of the field meter are not in error (see

Troubleshooting Procedures). The alternative is to replace the monitoring sonde or sensor with a calibrated backup unit and repair the malfunctioning monitor in the laboratory or return it to the manufacturer for repair.

\section{Field Cleaning of Sensors}

Most commercially available temperature sensors can be cleaned with a detergent solution and a soft-bristle brush. Film on the sensor that resists removal usually can be removed by soaking the sensor in a detergent and water solution (Ficken and Scott, 1989), but the manufacturer's recommended cleaning procedures should be followed carefully for multiparameter sensor systems.

Radtke, Davis, and Wilde (1998) recommend cleaning the specific conductance sensors thoroughly with de-ionized water before and after making a measurement. Oily residue or other chemical residues (salts) can be removed by using a detergent solution. Specific conductance sensors can soak in detergent solution for many hours without damage. Oil or other residues can be removed by dipping the sensor in a solvent or diluted hydrochloric acid solution (5 percent), but the manufacturer's recommendations should be checked before using acid solution or solvents on sensors. The sensor should never be in contact with acid solution for more than a few minutes. Carbon and stainless steel sensors can be cleaned with a soft brush, but platinum-coated sensors should never be cleaned with a brush.

Routine cleaning of DO sensors includes the use of a soft-bristle brush to remove silt from the outside of the sensor, wiping the membrane with a damp towel, and then rinsing with de-ionized water. The sensor usually is covered with a permeable membrane and filled with a potassium chloride solution. The membrane is easily fouled and will need to be replaced at least every 30 days, or as needed. When the membrane is replaced, the potassium chloride solution 
should be rinsed out of the sensor with de-ionized water, followed by several rinses with potassium chloride solution before the sensor is refilled. The membrane must be replaced with care so that the surface of the membrane is not damaged or contaminated with grease and no bubbles are trapped beneath the membrane. The surface of the membrane should be smooth, and the membrane should be secured tightly with the retaining ring. The sensor should be stored in water overnight to relax the membrane before installation and calibration. This procedure normally requires either replacing the DO sensor or revisiting the site for calibration at a later date,

Inspection of the DO sensor must be noted in detail on the field sheet. The gold cathode of the DO sensor can be fouled with silver over an extended period of time, and a special abrasive tool usually is required to recondition the sensor. A fouled anode, usually indicated by the white silver electrode turning grey or black, can prevent successful calibration. As with the cathode, the sensor usually can be reconditioned as directed by the manufacturer. Following reconditioning, the sensor cup must be refilled with potassium chloride solution and a new membrane installed.

The $\mathrm{pH}$ electrode must be kept clean and the liquid junction (if applicable) free flowing in order to produce accurate $\mathrm{pH}$ values (Radtke, Busenberg, and others, 1998). The body of the electrode should be thoroughly rinsed with de-ionized water before and after use. In general, this is the only routine cleaning needed for $\mathrm{pH}$ electrodes; however, for specific cases of fouling or contamination, the manufacturer's cleaning instructions must be followed. All cleaning and maintenance on the $\mathrm{pH}$ sensor are recorded in the instrument log book.

Optical sensors are extremely sensitive to fouling; thus, frequent maintenance trips may be necessary to prevent fouling of the turbidity sensor in an aquatic environment high in sediment build up, algae accumulation, larvae growth, or other biological or chemical debris. Mechanical cleaning devices or shutters that remove or prevent this build up are available for modern sensors. If the turbidity sensor is not equipped with a mechanical cleaning device that removes solids accumulation or a shutter that prevents build up on the lens before readings are recorded, reliable data collection will be more difficult.

\section{Field Calibration of Sensors}

A water-quality monitoring sensor or sonde should be calibrated in the laboratory before installation at a field location. Calibration in the laboratory or the field is done only by using standards of known quality. Field calibration is performed if the cleaned sensor readings obtained during the calibration check differ by more than the calibration criteria (table 6). Spare monitoring sondes or sensors are used to replace water-quality monitors that fail calibration after troubleshooting steps have been applied (see Troubleshooting Procedures). All calibration equipment must be kept clean, stored in protective cases during transportation, and protected from extreme temperatures.

\section{Temperature Sensors}

Modern water-quality temperature sensors are quite sturdy and accurate, and the manufacturers commonly make no provisions for field calibration of the temperature sensor. Monitoring temperature sensors generally are not calibrated, but comparisons of temperature readings are made by using Districtcertified thermometers or thermistors as described by Radtke, Kurklin, and Wilde (1998). Temperature accuracy is especially important because of the effect of temperature on the performance of other sensors. Before the field trip, the "District Certification" labels on thermometers or thermistors must be checked for the last date of certification and whether the instruments are appropriate for use in extreme field conditions.

The water-quality monitoring temperature sensor and the calibrated field thermistor are placed adjacent to one another, preferably in flowing water. If a liquid-in-glass thermometer is used, it must be the total-immersion type. Sufficient time for temperature equilibration must elapse before a reading is made. The two temperature sensors must be read and the temperatures recorded within 2 minutes. If the monitoring temperature sensor fails to agree within $\pm 0.2^{\circ} \mathrm{C}$, troubleshooting steps must be taken; if calibration fails, the sensor should be replaced. The faulty sensor or sonde should be returned to the manufacturer for proper calibration or repair.

\section{Specific Conductance Sensors}

If sensor inspection and cleaning processes fail to bring a specific conductance sensor within the 
calibration criteria (table 6), the sensor must be calibrated. Field calibration differs among the types of available instruments but generally relies on calibration with two standard solutions, bracketing the expected range of environmental conditions, and a third standard solution near the ambient specific conductance value of the water. All calibration information is recorded on the field sheet and in the monitoring instrument log.

Sensor inspection and field cleaning procedures must be followed to confirm that the monitor thermistor and the field thermistor or thermometer agree within $\pm 0.2{ }^{\circ} \mathrm{C}$. Expiration dates for the standard solutions should be checked, and the standard solution bottles must be allowed to equilibrate with the stream temperature (by soaking 15 to 30 minutes). The sensor, thermistor or thermometer, and measuring container are rinsed three times with a standard solution that approximates ambient conditions. Fresh standard solution is poured into the measurement container; the temperature setting is adjusted if necessary; the specific conductance, the standard values, and the temperature are read and recorded in the field notes and the monitoring instrument log; and the monitor reading is adjusted to the standard solution value. A temperature correction may be necessary if the monitor does not have automatic temperature correction (Radtke, Davis, and Wilde, 1998).

The used standard solution is discarded into a waste container, and the procedure is repeated using the second and third standard solutions. The monitor readings for the standards are read and recorded in the field notes and the instrument log. If the monitor sensor readings differ from the standards by more than $5 \mu \mathrm{S} / \mathrm{cm}$ or 3 percent, whichever is greater, the calibration sequence must be repeated. If the second calibration sequence still differs by more than the calibration criteria, troubleshooting techniques will need to be attempted (see Troubleshooting Procedures). If these steps fail, the sonde or monitoring sensor must be replaced and the backup instrument calibrated.

\section{Dissolved Oxygen Sensors}

Dissolved oxygen in water is related to water temperature, atmospheric pressure, and salinity. Radtke, White, and others (1998) provide detailed calibration steps for four different procedures: (1) aircalibration chamber in water, (2) air-saturated water, (3) air-calibration chamber in air, and (4) iodometric (Winkler) titration. The first three procedures determine DO by an amperometric method that depends on diffusion of oxygen through a Teflon membrane. The iodometric titration measures DO directly by a dye color change upon reduction of available oxygen. The appropriate procedure depends on the type of monitoring equipment. Manufacturer's calibration procedures should be followed closely to achieve a calibrated accuracy of $\pm 0.3 \mathrm{mg} / \mathrm{L} \mathrm{DO}$. In general, calibration of DO sensors involves measuring DO at 100-percent saturation and measuring a zero-DO solution. For measured temperature and atmospheric pressure, the saturated DO is obtained from a table developed by Weiss (1970) and reproduced in Radtke, White, and others (1998). Ambient atmospheric pressure should be determined with a calibrated pocket barometer to the nearest $1 \mathrm{~mm}$ of mercury.

In sea water or brackish water, a salinitycorrection factor must be applied to the measured DO concentration. Manufacturer's instructions should be referred to before applying a correction for saline waters (waters with specific conductance values greater than $2,000 \mu \mathrm{S} / \mathrm{cm}$ or chloride concentrations greater than $1,000 \mathrm{mg} / \mathrm{L}$ ); but generally, specific conductance values less than $8,000 \mu \mathrm{S} / \mathrm{cm}$ have correction factors less than the calibration criteria of the monitoring sensor for DO. For specific conductance values greater than $8,000 \mu \mathrm{S} / \mathrm{cm}$, refer to salinity correction tables developed by Weiss (1970) and reproduced in Radtke, White, and others (1998).

A fresh zero-DO standard solution should be prepared before each field trip, as described by Radtke, White, and others (1998). Calibration at 100-percent saturation in the field presents a problem because replacement of the Teflon membrane frequently is required, and the replaced membrane must be allowed to "relax" in water for 24 hours before calibration. One solution to this problem is to carry clean and serviced spare DO sensors, stored in water, to the field. The replacement DO sensors can then be calibrated in the field, and an interruption in the record and a next-day return site visit can be avoided. Direct measurement of ambient DO with the iodometric procedure requires preventing exposure of the sample to atmospheric oxygen, and this often makes accurate and precise field determinations difficult. The accuracy of this procedure also depends on the experience and technique of the data collector (Radtke, White, and others, 1998). 


\section{$\mathrm{pH}$ Sensors}

Field calibration of $\mathrm{pH}$ sensors is often a timeconsuming process that requires patience. Before going to the field, the field meter $\mathrm{pH}$ response and thermistor should be checked, as described by Radtke, Busenberg,

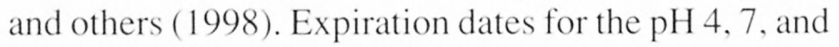
10 buffers should be checked, and spare monitoring $\mathrm{pH}$ sensors or backup sondes will need to be prepared in case replacement of field sensors is required.

Upon arrival at the field site, the tightly capped buffer solutions are placed in the stream to allow time for temperature equilibration, usually 15 to 30 minutes. The $\mathrm{pH}$ sensor is checked for physical damage and replaced if necessary. Sensor inspection and fieldcleaning procedures are followed as described by the manufacturer or Radtke, Busenberg, and others (1998). If the $\mathrm{pH}$ monitoring sensor reading exceeds the calibration criteria (table 6), the monitoring sensor should be calibrated as described by the manufacturer's instructions.

Temperature effects on $\mathrm{pH}$ buffer solutions vary with individual solutions, and the temperaturecorrection factor should be checked with the manufacturer. See Appendix 5 for examples of common $\mathrm{pH}$ buffer solution variances with temperature. The $\mathrm{pH}$ sensor reading should be standardized to the temperature-corrected $\mathrm{pH}$ value. The $\mathrm{pH}$ sensor, thermistor or thermometer, and measurement container are rinsed with $\mathrm{pH}-7$ buffer solution, which is then discarded along with all subsequent rinsates in a waste container. Fresh pH-7 buffer solution is poured into the rinsed measurement container, and the instruments are allowed to equilibrate for 1 minute before the buffer solution is discarded and fresh pH-7 buffer solution is poured into the measurement container. The solution is slowly stirred with the $\mathrm{pH}$ sensor or sonde. The temperature, $\mathrm{pH}$, and associated millivolt reading are measured and recorded. This standardization process is repeated with fresh $\mathrm{pH}-7$ buffer solutions until two successive values of the temperature-adjusted $\mathrm{pH}-7$ readings are obtained.

The $\mathrm{pH}$ sensor, thermistor or thermometer, and measurement container are rinsed with de-ionized water, and the standardization process is repeated with a pH-4 or pH-10 buffer solution to establish the response slope of the $\mathrm{pH}$ sensor by choosing the buffer that brackets the expected range of $\mathrm{pH}$ values. The second temperature-corrected $\mathrm{pH}$ value, temperature, and millivolt readings are recorded, and the $\mathrm{pH}$ sensor, thermistor or thermometer, and measurement container are rinsed with de-ionized water. The $\mathrm{pH}-7$ buffer solution is then used to rinse, fill, and check the $\mathrm{pH}-7$ calibration measurement. If the $\mathrm{pH}$ sensor reading is $7 \pm 0.1 \mathrm{pH}$ units, the slope adjustment has not affected the calibration. If the accuracy standard is not met, the calibration and slope adjustment steps must be repeated. If the repeated calibration and troubleshooting steps fail, the $\mathrm{pH}$ sensor or monitoring sonde must be replaced.

Once the slope adjustment step is completed satisfactorily, the third buffer solution can be used as a calibration range and linearity check. The temperature and $\mathrm{pH}$ values are read and recorded, but the \pm 0.1 accuracy should not be expected to be achieved over the full range from $\mathrm{pH} 4$ to $\mathrm{pH} 10$ for a monitoring sensor.

Waters with specific conductance values less than $100 \mu \mathrm{S} / \mathrm{cm}$ require special low-ionic strength buffers and $\mathrm{pH}$ sensors. The extra preparations, precautions, and troubleshooting steps for measuring low-ionic strength waters are described by Busenberg and Plummer (1987).

\section{Turbidity Sensors}

Field inspection or calibration of the turbidity sensor is made by using Formazin or other approved primary standards and following the manufacturer's calibration instructions as described by Wilde and Gibs (1998). Turbidity standards with various ranges are commercially available, and most sensor manufacturers recommend either Formazin or SDVB polymer standards for calibrating turbidity sensors. Formazin-based standards can be diluted by using a dilution formula; however, errors may be introduced during the dilution process, thus reducing the accuracy of the standard solution. Turbidity-free water, used in the preparation of standards, dilution, and rinsing, is prepared as described by Wilde and Gibs (1998).

Sensors should first be inspected for damage, ensuring that the optical surfaces of the probe are in good condition. Before placing the turbidity sensor in standards, the sensor should be cleaned, rinsed three times with turbidity-free water, and carefully dried. If the readings are unusually high or erratic during the sensor inspection, entrained air bubbles may be present on the optic sensor and need to be removed. If the sensor readings exceed the calibration criteria (the greater of \pm 5 percent or $2 \mathrm{NTU}$ ) during the inspection process, the sensor must be calibrated by following the 
manufacturer's instructions. A three-point calibration process is recommended, covering the expected range of values, although some instruments may be limited to calibration with only one or two standards. If the instrument allows only a two-step process, then two primary standards covering the expected range should be used for calibration and a third mid-point standard used to check for linearity. Similarly, if the instrument requires calibration only with turbidity-free water and one standard, another mid-point standard should be used to check for linearity.

\section{Cross-Section Measurements}

The data objectives for most continuous waterquality monitoring sites require that the sensors be installed in locations that are most representative of stream cross sections. A minimum of two cross-section measurements per year is required to verify that no significant changes in the distribution of physical properties have occurred. Variability in some streams may require more frequent measurements. For sites that are operated more than 1 year, a minimum of six cross-section measurements representing different seasons and flow conditions is required to determine if discharge or seasonal changes have significantly affected the distribution of constituent values in the cross section (see Placement of Sensors in the Cross Section for details).

\section{Troubleshooting Procedures}

When a parameter cannot be calibrated with standard solutions, the hydrographer must determine if the problem resides with the monitoring sensor or with the monitor itself and make necessary corrections to ensure that the monitor is operational. The hydrographer should carry spare sensors and sondes so that troubleshooting, if necessary, can be accomplished at the time of the service visit. Troubleshooting in the field can prevent the need for extra trips and greatly reduce lost record and the amount of time spent in processing the records in the office later. A successful service trip results in a properly calibrated and operating monitor. Some of the more common problems that are likely to be encountered in the field when servicing monitors are listed in Appendix 6 to assist in the troubleshooting process.

\section{Field Notes and Instrument Logs}

Field notes and instrument logs are the basis for the accurate and verifiable computation of waterquality monitoring records. Minimum requirements in the field notes for water-quality monitors include the following items:

- Station number and name

- Name(s) of data collector(s)

- Date and times of each set of measurements

- Field meter and monitor serial or "W" numbers

- Purpose of the site visit

- Horizontal and vertical locations of sensors in the cross section (if applicable)

- Recorded monitor values and corresponding field values (initial, after cleaning, and final instream readings)

- Cross-section measurement data (locations of verticals, constituent values, and measurement time)

- Cross-section measurement summaries and corrections

- Pertinent gage-height data

- Remarks that describe channel conditions, condition of the sensors, and so forth

- Battery voltage of monitor at arrival and departure (replaced?)

- Were sensors changed or replaced? (other remarks or observations that may aid in further processing of the record)

Forms including these items encourage consistency and help to avoid the costly omission of critical information. A field form that constitutes a comprehensive checklist for data collection at many water-quality monitoring sites is shown in Appendix 4. Alternative forms should be approved by the USGS District waterquality specialist.

Each field meter and water-quality monitor has an instrument log book, and all pertinent information regarding the monitor is recorded in the instrument log book. One of the most significant pieces of recorded information is the instrument calibration-both field and laboratory. Calibration information can be recorded initially on field forms or field notebooks, but the information then must be copied into the instrument log book. The instrument log book should contain a complete record of all maintenance in the field, the laboratory, or by the manufacturer. Permanent instrument logs contain critical calibration and 
maintenance information that document instrument performance throughout the useful service life of the instrument. Calibration log information that is important from a record-processing standpoint includes:

- Calibration dates, times, and temperatures

- Calibration standard values and lot numbers

- Initial and final monitor calibration data

- Field meter calibration values

Field notes and calibration log information should be clearly written, and all notations should be self explanatory. The goal is to have sufficient information for another individual to complete the record processing steps, if necessary. Clear notes simplify the record check and review processes.

\section{RECORD COMPUTATIONS}

The record-computation process is accomplished to verify the data and document its quality. Accurate field notes and calibration logs are essential in processing the record. The hydrographer who services the water-quality monitoring installation typically computes the water-quality data record; writes the manuscript that describes the data; updates the station description and station analysis; and prepares the data record review package.

The primary steps in processing the record are an initial data evaluation, application of corrections and shifts, application of cross-section corrections, and a final data evaluation. The initial data evaluation should begin immediately upon completion of the field trip to ensure that all necessary information is available and to check for possible instrument malfunctions that may not have been observed in the field. Record checks and review of the record confirm that the data are accurate and ready for publication.

\section{Data-Processing Procedures}

The processing of water-quality monitoring records should be completed in a timely manner according to water-quality-assurance plan policies. Complete and accurate field notes are an important part of the data processing and reduce the amount of time required to process the data. Corrections to data should not be made unless the causes of errors can be validated or explained by information or observations in the field notes or by comparison to information from adjacent stations (Ritz and others, U.S. Geological Survey, written commun., 1998). Ritz and others summarize data processing as a process that can be classified in six major categories: (1) initial data evaluation, (2) application of corrections and shifts, (3) application and evaluation of cross-section corrections, (4) final data evaluation, (5) record checking, and (6) record review. The first four categories are discussed in this section, and the latter two categories are combined in the section Preparation of the Review Package.

\section{Initial Data Evaluation}

The initial data evaluation checks the success of the transfer of raw field data (instrument readings) to the office data base and provides the opportunity for initial checks to evaluate and correct erroneous data (daily, if telemetry is available). Raw field data may be stored in a variety of formats, depending on the recording equipment and the means of downloading data from the recording equipment. The conversion of raw data from a variety of recording devices into a standard entry format to the District data base, or Automated Data-Processing System (ADAPS), generally is accomplished with the use of an on-line computer program, or Device Conversion and Delivery System (DECODES). After entry of data into ADAPS, primary data tables and plots can be produced for review. See Appendix 7 for an example of a primary data table.

Sensors, recorders, transmitters, receivers, relays, transmission systems, or unforeseen events can, at times, produce unexplainable data. Data should be reviewed daily, if possible, to edit obviously erroneous data caused by data transmission problems. Data should be processed immediately after the service visit and viewed graphically. In addition to confirming the accurate transfer of data, this may aid in detecting instrument or sensor errors. Data that are missing (for example, because of instrument or transmission problems) should not be estimated, but missing data should be documented and no statistics should be calculated that involve missing data. An example in figure 4 of data record for a continuous specific conductance monitor shows truncated record at the default maximum setting of the data logger.

Exceedance of the default maximum was not noticed during routine site visits, and because the record was not computed and viewed graphically after service visits, the truncated maximum values were not 


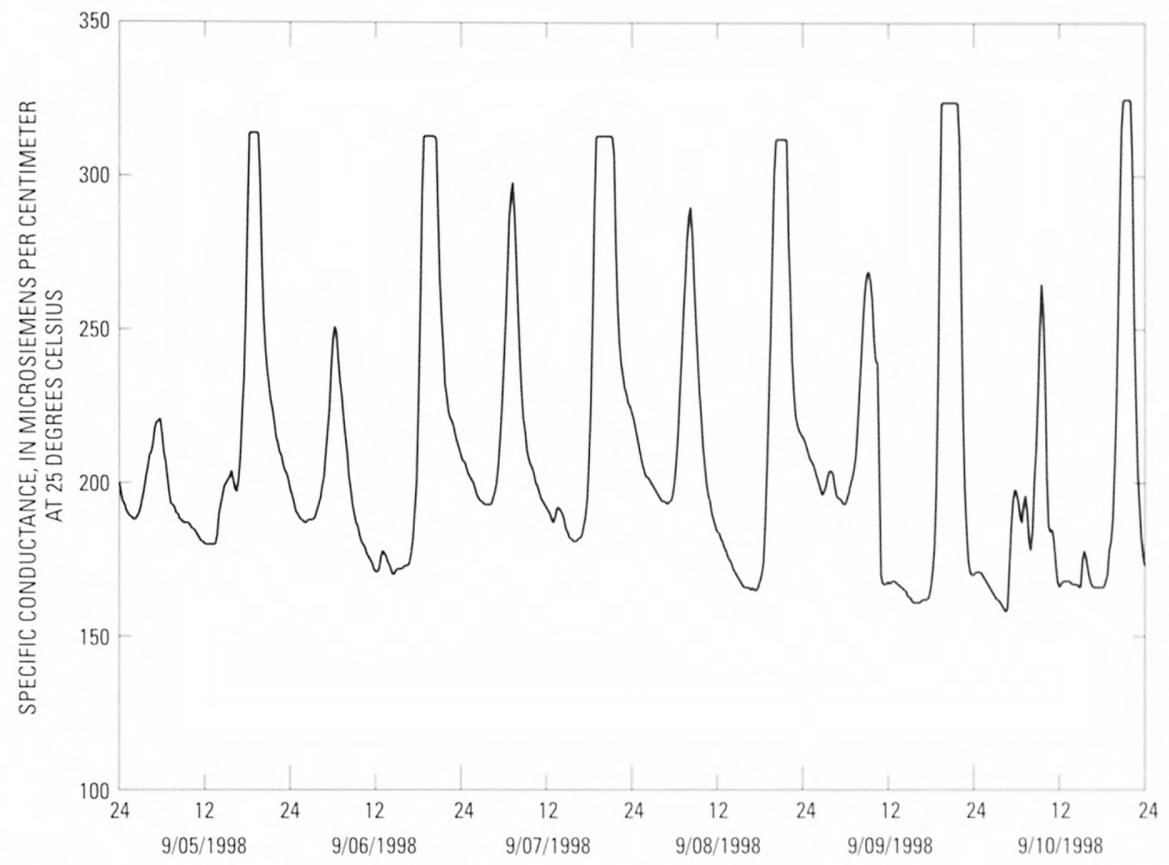

Figure 4. Specific conductance at Duwamish River at Tukwila, Washington, September 5-10, 1998.

observed until the end of the year. Only minimum values were published for the period of record with truncated values, and the manuscript station description noted that maximum values may have been exceeded during periods of missing record (see Data Qualification Statements for details).

Great emphasis has been placed on the relation between variations of the five water-quality properties (temperature, specific conductance, DO, pH, and turbidity) and discharge variations, but other eventrelated changes are equally important and can be factored into the relation only through field experience and first-hand observation at a site. Some examples include changes in air temperature, periods of sustained cloud cover, chemical spills, increased photosynthesis (influenced by a variety of factors), increased wind conditions, combined sewer overflows, forest fires in the watershed, road construction, and ice formation.

As mentioned previously, temperature, specific conductance, $\mathrm{DO}, \mathrm{pH}$, and turbidity have complex interdependencies. Understanding these relations is a necessary component for accurate water-quality record computation. Periodically visiting the upstream portions of the drainage basin and keeping field notes on evidence of changes in land-use activities are helpful in explaining observed changes in water quality.

\section{Application of Corrections and Shifts}

The application of corrections and shifts allows data to be adjusted to compensate for errors that occurred during the service interval as a result of environmental or instrumentation effects. Three types of measurement-error corrections are described here-fouling, drift, and cross-section correction. Corrections only should be made to measurements when the type and degree of correction is known. Because of the complex interdependencies of temperature and the other measured physical properties, a malfunctioning thermistor can invalidate some or all of the other measured physical properties. The permeability of a DO membrane, for example, changes the DO concentration 3 percent for each temperature change of $1{ }^{\circ} \mathrm{C}$ (Wilde and Radtke, 1998). Specific conductance also can vary as much as 3 percent per $1{ }^{\circ} \mathrm{C}$.

The sequence for determining the type and degree of measurement error in the field and the application of corrections in ADAPS generally is fouling, drift, and cross-section correction. If the deviation between actual value and sensor reading exceed the criterion for water-quality data shifts (table 7), a correction is required. The correction is a linear interpolation over the time between sensor inspections. 
Table 7. Criteria for water-quality data shifts

$\left[ \pm\right.$. plus or minus value shown; ${ }^{\circ} \mathrm{C}$, degree Celsius; $\mu \mathrm{S} / \mathrm{cm}$, microsiemens per centimeter at $25^{\circ} \mathrm{C}$; mg/L, milligram per liter; $\mathrm{pH}$ unit, standard $\mathrm{pH}$ unit; NTU, nephelometric turbidity unit]

\begin{tabular}{|l|l|}
\hline $\begin{array}{c}\text { Measured physical } \\
\text { property }\end{array}$ & \multicolumn{1}{c|}{$\begin{array}{c}\text { Shift criteria } \\
\text { (apply shift when deviation exceeds this } \\
\text { value) }\end{array}$} \\
\hline $\begin{array}{c}\text { Temperature (may } \\
\text { affect the other } \\
\text { physical properties) } \\
\begin{array}{l}\text { Specific conductance } \\
\text { The greater of } \pm 5 \mu \mathrm{S} / \mathrm{cm} \text { or } \pm 3 \text { percent } \\
\text { of the measured value } \\
0.3 \mathrm{mg} / \mathrm{L}\end{array} \\
\begin{array}{l}\text { Dissolved oxygen } \\
\text { pH }\end{array}\end{array}$ & $\begin{array}{c}0.2 \mathrm{pH} \text { unit } \\
\text { The greater of } \pm 2 \text { NTU or } \pm 5 \text { percent } \\
\text { of the measured value }\end{array}$ \\
\hline
\end{tabular}

The same measurement criteria used to determine the need for calibration (table 6) are used to determine the need for water-quality data shifts. In general, shifts are required when the deviation between actual and recorded data exceed the shift criteria listed in table 7.

The allowable limits shown in table 7 are minimal requirements. More stringent requirements may be required to meet the data objectives of the project or particular hydrologic and chemical environments and are determined at the discretion of the project chief or District water-quality specialist.

The example of graphic corrections in Appendix 8 shows two standards that exceed the shift criteria. Deviation from the value of the third standard does not exceed the shift criteria, but the shifted values also are shown if shifts were made for the third standard. The quality of data is excellent whether or not the shift is made (see Publication Criteria section); thus, shifting the data does not improve the data. Decisions for data shifts and corrections must be resolved by the hydrographer and members of the review team.

Decisions about the costs of more frequent service visits compared to the decrease in accuracy and precision in the record must be considered carefully for every water-quality monitoring site for various seasons and flows. It generally is understood that the more publishable record there is for a site, the more consistently the data objectives can be met for accuracy and precision. So it follows that it may take some time to finalize the appropriate service intervals at new installations.

\section{Fouling}

Fouling may result from several sources and also may be event-related. Identification of electronic drift or loss of sensor sensitivity should be distinguished from fouling drift, if at all possible. The degree of fouling is determined from the difference between sensor measurements before and after the sensors are cleaned.

Modern temperature sensors are sturdy, dependable, and resistant to fouling. Fouling has the least effect on temperature sensors, which is fortunate because modern sensor packages use internal thermistors to provide continuous temperature corrections to specific conductance, $\mathrm{DO}, \mathrm{pH}$, and turbidity values, all of which are temperature dependent.

Specific conductance sensors can be affected by fouling problems when mineralization, severe sedimentation (for example, during the recession period of a flood), or aquatic growth occurs. In general, the sensors are sturdy, easy to clean, and the calibrated field meters are reliable. The specific conductance correction for fouling generally is a datum correction.

Dissolved oxygen sensors are susceptible to fouling of the Teflon membrane, loss of elasticity of the membrane, and chemical alteration of the cathodeanode measuring electrodes. Fouling of the membrane can include coating from organic or oily substances, siltation, attachment of aquatic organisms (for example, barnacles in estuarine locations), growth of algae, or deposition of other materials. Replacement of the sensor membrane is simple but requires calibration and eliminates the ability to distinguish drift from fouling. The reconstruction of reliable record ranges from straight forward (for example, onset of a flood) to complex (for example, gradual growth of an algal coating). The DO error correction for the appropriate part of the service interval generally is by use of a datum correction in ADAPS.

Chemical alteration of the DO electrodes can be caused by either a strong oxidizing or reducing chemical agent, such as in a spill situation, a metal-rich drainage basin, or organic-rich waters, such as a wetland. A more common alteration is sulfide poisoning over a longer period of time. Poisoning would be corroborated by chronically low dissolvedoxygen readings, even after sensor membrane replacement. For many investigations, sulfide poisoning usually is evident as a grey or black color on the silver anode. 
Continuous records of DO and turbidity are often the most difficult to maintain within acceptable limits for accuracy and precision. Because of this, the time period between service visits may need to be shortened to maintain the quantity and quality of the DO or turbidity record. Sensor fouling, as a result of biological or chemical particles accumulating on the sensors, can occur on any monitor left in the stream for a period of time. Although fouling frequently begins as soon as the monitor is placed in the stream for deployment, a rise in gage height generally will contribute more to fouling overall. If a turbidity probe is equipped with wiper or shutter technology and is properly maintained, the need for a fouling correction will be minimized. The optic mechanism on the turbidity sensor is extremely sensitive to build up; if the probe is not equipped with wiper or shutter technology, accuracy of turbidity data will be impaired significantly. A fouling shift generally is applied as a datum correction from either the last time the sensor was cleaned, from the last rise in gage height, or from a significant event noted in the field notes.

Fouling of a pH sensor can be similar to the fouling of a DO membrane. The $\mathrm{pH}$ sensor must be cleaned delicately in order to avoid scratching the glass surface, which would render it useless. The before- and after-cleaning measurements of $\mathrm{pH}$ are critical because the chance of sensor drift is higher for $\mathrm{pH}$ than for the other four sensors. Distinction between drift and fouling in the field may be difficult; since replacement of a pH sensor is often required as a troubleshooting step, it may not be possible to distinguish drift from fouling. Accurate instrument log information on $\mathrm{pH}$ monitors is vital in recognizing sensor as opposed to monitor malfunctions. The consequence in ADAPS is a single datum correction for both drift and fouling. The preferred method of correction in ADAPS is the variable shift program.

\section{Drift}

A calibration drift is an electronic drift in the equipment from the last time it was calibrated and is determined by the difference between readings of a cleaned sensor in standards or buffers and a calibrated sensor. If, after checking, the deviation from calibrations is within the calibration criteria of the sensor (table 6), then no sensor drift is present. Drift is assumed to occur at a constant rate across the service interval. If the sensor readings exceed the shift criteria (table 7), then the correction is a linear interpolation over the time between calibration checks. This is called a prorated shift in ADAPS (Bartholoma, 1997) and is illustrated for temperature in figure 5 .

The Automated Data-Processing System (ADAPS) does not have an option for recording the percentage of shift by recorded value, but it does have a provision that allows three standards to be entered as value adjustments for a measured parameter.

Corrections to the record can thus be applied as a 3-point variable shift in ADAPS. This value-dependent adjustment is called a variable shift and is applied in situations where standards at the beginning and ending of the service interval have different amounts of deviation (variable shifts). The equivalent situation

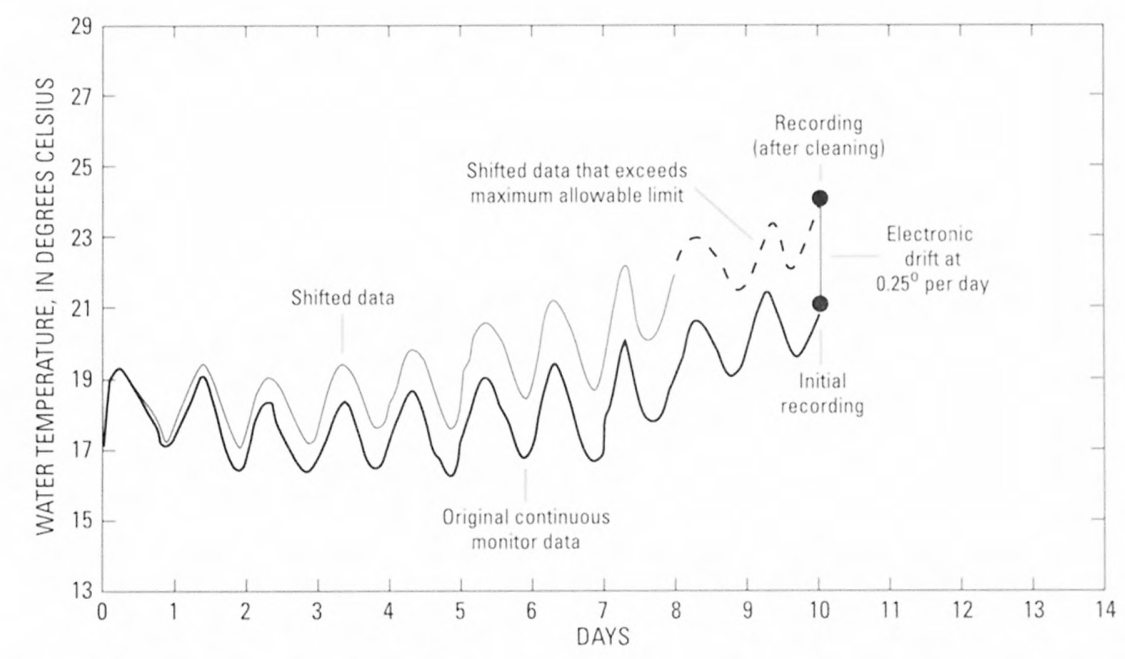

Figure 5. Generalized graph of corrections to continuous temperature record. 
for computation of streamflow in ADAPS is called a V-shift (Bartholoma, 1997). A graphic representation of a variable shift for specific conductance is shown in Appendix 8. Variable shifts can be accomplished for any parameter, and this is the recommended technique for corrections related to instrument drift. Because three standards frequently are used for monitor calibration, the variable shift is the preferred method of correction for drift (see Appendix 8).

The treatment for suspected sensitivity loss is sensor reconditioning or replacement. The $\mathrm{pH}$ sensors are particularly prone to sensitivity loss (Busenberg and Plummer, 1987). Sensitivity loss in the pH sensor may result from a partially clogged reference electrode junction or a change in the concentration of the potassium chloride filling solution. Distinguishing between $\mathrm{pH}$ sensor drift and electronic drift is possible by determining the sensor slope; however, the correction is the same. Improvements in electronic devices in the past two decades have greatly reduced the amount of true electronic drift.

\section{Evaluation and Application of Cross-Section Corrections}

The purpose of cross-section corrections is to adjust the measurements of the monitoring equipment to reflect conditions more accurately in the entire stream cross section, from bank to bank and surface to bottom. The principal value of such adjusted measurements is realized when concurrent discharge measurements permit the computations of constituent loads transported past the station. Primary tables and plots from ADAPS that represent drift and fouling corrections should be made before the application of corrections to the cross section. The application of cross-section corrections is intended to improve the accuracy and representativeness of monitoring measurements; however, cross-section corrections should be made only if the variability in the cross section exceeds the shift criteria.

Corrections to the cross section are based on field measurements taken both horizontally and vertically in the stream cross section. Shared characteristics of the specific corrections for temperature, specific conductance, DO, pH, and turbidity are that they may differ from each other at each site, and they all are site dependent and may be discharge and seasonally dependent as well. Several considerations govern the use of corrections. Crosssection measurements must be made under a variety of flow conditions (minimum of six), all seasonal conditions, and at least twice annually to confirm that the correction being applied to the water-quality measurements truly represents the median or mean cross-section values. Corrections should not be applied to water-quality measurements beyond the range of discharge measurements nor during periods of unsteady flow. If the correction for a measured physical property is consistent across a range of discharges and seasons, then correction of the measurement values by simple adjustment is warranted. Seasonal changes in water quality may be representative of the hydrologic system, but they also may be a result of local conditions.

Often, an increase in specific conductance may accompany low-flow conditions in basins where ground water has higher specific conductance than surface water. It is important to consider, however, that during summer low-flow conditions, extremes in temperature, $\mathrm{pH}$, and DO may be representative of local biological activity rather than seasonal or discharge-related cross-sectional variability. Professional judgment and observations in the field logs will assist in evaluating the need for the application of cross-section corrections. Continuous water-quality monitoring has great value in recognizing the interdependence of water-quality physical properties under varying flow regimes. Understanding these relations is essential in the appropriate application of discharge-dependent corrections.

\section{Final Data Evaluation}

Final data evaluation consists of reviewing the data record, checking shifts, and making any needed final corrections. When completed, the data are verified for publication and then rated for quality. Data that cannot be verified or are rated as unacceptable are retained for record-checking and review purposes but are not published or stored in ADAPS. Unacceptable or unverified data, however, should be archived following established District policies.

\section{Maximum Allowable Limits for Reporting Continuous Data}

Systematic adoption of a standardized final dataevaluation process, including maximum allowable limits and publication criteria, are important components in finalizing District water-quality records. Many USGS District offices have established quality-control limits for shifting data. These 
commonly are referred to as "maximum allowable limits." The concept is simple - if the recorded values differ from the field-measured values by more than the maximum allowable limits, the data are not published. For the purpose of consistency within the USGS and to inform data users of the maximum allowable limits, the limits are established at 10 times the calibration criteria, except for more stringent requirements for DO and turbidity, for all standard continuous-monitoring, data-gathering activities (table 8).

Table 8. Maximum allowable limits for continuous waterquality monitoring sensors

L_. plus or minus value shown: "C. degree Celsius; mg/L, milligram per liter: $\mathrm{pH}$ unit, standard $\mathrm{pH}$ unit ]

\begin{tabular}{|l|l|}
\hline \multicolumn{1}{|c|}{$\begin{array}{c}\text { Measured physical } \\
\text { property }\end{array}$} & \multicolumn{1}{c|}{$\begin{array}{c}\text { Maximum allowable limits for water-quality } \\
\text { sensor values }\end{array}$} \\
\hline \hline Temperature & $\pm 2.0{ }^{\circ} \mathrm{C}$ \\
Specific conductance & \pm 30 percent \\
Dissolved oxygen & The greater of $\pm 2.0 \mathrm{mg} / \mathrm{L}$ or 20 percent \\
$\mathrm{pH}$ & $\pm 2 \mathrm{pH}$ units \\
Turbidity & \pm 30 percent \\
\hline
\end{tabular}

The maximum allowable limits shown in table 8 are considered minimum standards for quality, and Districts are encouraged to establish stricter requirements. Even with the establishment of maximum allowable limits, professional judgment by the hydrographer still is needed in record processing. For example, a decision must be made regarding at what point in the data-collection interval the physical property values exceeded the maximum allowable limit. In the cases of instrument drift, gradual fouling, or event-related fouling, reasonable judgment can be made as to the time in the record interval when the maximum allowable limits were exceeded. The hydrographer computing the record and the record reviewer must agree on this determination and note the time when the maximum allowable limits were exceeded on the station analysis sheet.

\section{Publication Criteria}

An assessment of accuracy is required for the publication of all continuous water-quality records. After the record has been evaluated for maximum allowable limits, one of four accuracy classifications is applied to each measured physical property on a scale ranging from poor to excellent. The accuracy rating is based on data values recorded before any shifts or corrections are made (table 9).

Additional consideration must be given to the amount of publishable record and to the amount of data that have been corrected or shifted. Missing data or data that do not meet the criteria for maximum allowable limits can have much to little or no effect on the accuracy of the published data, depending on the situation; the decision to publish the data is left to the professional judgment of the hydrographer. However, to publish a daily value for any physical property, the following minimum requirements apply:

1. On days when less than 100 percent of the data collected at a discrete fixed or varying time interval (unit values) are available, in order to publish a daily mean value, both the expected daily maximum and daily minimum values must be present.

Table 9. Rating continuous water-quality records

I_. less than or equal to; _. plus or minus value shown: "C. degree Celsius: >. greater than: \%. percent: mg/L. milligram per liter: pH unit, standard $\mathrm{pH}$ unit ]

\begin{tabular}{|c|c|c|c|c|}
\hline \multirow{2}{*}{$\begin{array}{c}\text { Measured physical } \\
\text { property }\end{array}$} & \multicolumn{4}{|c|}{ Ratings } \\
\hline & Excellent & Good & Fair & Poor \\
\hline Water temperature & $\leq \pm 0.2^{\circ} \mathrm{C}$ & $> \pm 0.2$ to $0.5^{\circ} \mathrm{C}$ & $> \pm 0.5$ to $0.8^{\circ} \mathrm{C}$ & $> \pm 0.8^{\circ} \mathrm{C}$ \\
\hline Specific conductance & $\leq \pm 3 \%$ & $> \pm 31010 \%$ & $> \pm 10$ to $15 \%$ & $> \pm 15 \%$ \\
\hline Dissolved oxygen & $\leq \pm 0.3 \mathrm{mg} / \mathrm{L}$ & $> \pm 0.3$ to $0.5 \mathrm{mg} / \mathrm{L}$ & $> \pm 0.5100 .8 \mathrm{mg} / \mathrm{L}$ & $> \pm 0.8 \mathrm{mg} / \mathrm{L}$ \\
\hline $\mathrm{pH}$ & $\leq \pm 0.2$ unil & $> \pm 0.2$ to 0.5 unit & $> \pm 0.5$ to 0.8 unit & $> \pm 0.8$ unit \\
\hline Turbidity & $\leq \pm 5 \%$ & $> \pm 51010 \%$ & $> \pm 10$ to $15 \%$ & $> \pm 15 \%$ \\
\hline
\end{tabular}


2. Daily maximum and minimum values may be published independently if they occur during the expected times and when the following criteria are met:

Water temperature-A minimum of 25 percent of the unit values is present, and flow is gradually changing or at a steady state.

Specific conductance-A minimum of 50 percent of the unit values is present, and flow is gradually changing or at a steady state. Consider the relation of specific conductance to streamflow.

Dissolved oxygen-A minimum of 25 percent of the unit values is present, and flow is gradually changing or at a steady state. Consider the temperature and $\mathrm{pH}$ relation.

$\mathrm{pH}-\mathrm{A}$ minimum of 25 percent of the unit values is present, and flow is gradually changing or at a steady state.

Turbidity - A minimum of 50 percent of the unit values is present, and flow is gradually changing or at a steady state. Consider specific conductance/turbidity correlation. Reporting daily mean values when less than 100 percent of the unit values is available is a judgment decision and generally determined by data trends. If more than 50 percent of the recorded data is missing, then the mean value should be reported as estimated.

The current station description format for the USGS annual data report requires a description of the specific service interval ratings (Novak, 1985). The record-rating system described in this report must be systematically applied to all continuous water-quality monitoring data published in USGS reports. Accuracy ratings are listed in the REMARKS section of the station description for USGS annual reports. The appropriate rating and accuracy of each water-quality monitoring record also must be included in the station analysis form (see Preparation of the Review Package).

The calculation of daily mean $\mathrm{pH}$ values in ADAPS should be discontinued in District waterquality data-collection programs and replaced by the calculation of median daily $\mathrm{pH}$ values or a more accurate computational approach for the calculation of mean $\mathrm{pH}$ values. The correct calculation involves the conversion of $\mathrm{pH}$ units to hydrogen-ion concentrations. calculation of a mean concentration value, and conversion back into $\mathrm{pH}$ units (as shown in Appendix 1). This additional step is mathematically correct but tends to bias the results toward lower $\mathrm{pH}$ values than the simpler median value.

\section{Preparation of the Review Package}

Typically, the same individual who services the water-quality monitoring site also computes the waterquality monitoring record, writes the water-quality station analysis that describes annual operation of the site, makes necessary changes to the station description, and prepares a package of auxiliary information to aid in the review of the record.

\section{Record Checking}

All data used in producing the final water-quality record should be checked thoroughly for completeness and accuracy before final review and publication. The hydrographer who is responsible for computation of the water-quality record should review the record, followed by a second check for completeness and accuracy by an experienced hydrographer before final inspection by the USGS District water-quality specialist or District-designated reviewer. All field data should be verified for accuracy of transcription from field sheets; all shifts should be checked to assure that the correct values were used for a shift; and all dates and numbers in the station manuscript should be checked for accuracy.

\section{Station Description}

All stations are required to have a station description that identifies the location, history, and operation of the station. A complete description is prepared for each new station and is revised only upon changes in location or operation. The contents of a continuous water-quality station description vary, but in addition to the minimum requirements of location, history, and operation of the station, the station description includes information on instrumentation and the location and placement of water-quality sensors (see Appendix 2).

\section{Station Analysis}

An individual station analysis is required annually and includes an analysis of each constituent monitored at a site. The purpose of the station analysis is to compile information annually from the field notes, instrument log, and station description that bear directly on the accuracy and completeness of the record. At a minimum, the station analysis must include the instrumentation, period of record, sampling procedures, special conditions, and any variations from 
normal procedure (see Appendix 3). In addition, the station analysis includes information relating to the accuracy of the instrumentation and the record produced for the year, dates that probes were changed or replaced, procedures and methods used in the calibration process, a statement of how corrections or shifts were applied to the data, and any unusual events that may have affected the record. Reasons are given for how data were validated or why anomalous record was removed or retained. Details are recorded relating to how and when cross-section measurements were made and variations throughout the cross section.

\section{Contents of the Review Package}

The record review package includes the following figures, forms, or tables (examples of the figures, forms, or tables are included in the Appendix section of this report):

1. Station description form (Appendix 2)

2. Station analysis form (Appendix 3)

3. USGS Water-Quality Monitor Field-Inspection Form (Appendix 4)

4. Primary computations table from ADAPS (Appendix 7)

5. Annual data report draft manuscript (Appendix 9)

6. Annual field measurement summary form (Appendix 10)

7. Water-quality variable shift correction tables from ADAPS (Appendix 11)

8. Datum correction value table from ADAPS (Appendix 12)

9. Computed (type 3) daily-values tables (Appendix 13)

10. Discharge hydrograph (Appendix 14)

11. Graph of individual water-quality physical property for review (Appendix 15)

\section{Documentation}

The methods for collecting, correcting, and processing continuous water-quality monitoring data are defined and publication standards are established. Systematic application of monitoring site operation, the record rating system, and a standard record-review process are part of the necessary quality assurance in producing and documenting complete and accurate water-quality monitoring records. The use of
DECODES for data conversion and ADAPS for data processing ensures national consistency and a valid data trail. Additionally, participation in the National Field Quality-Assurance Program (Stanley and others, 1998) ensures the proficiency of the analyst and the instruments used in making measurements.

\section{Level of Review Required}

Another individual (a senior colleague or section supervisor) examines the record-review package for completeness and accuracy. If areas of interpretation exist (for example, when to start or terminate a shift), a discussion between these two individuals is held. When all issues are resolved, the decisions are documented on the appropriate form. The completed record-review package is then inspected by the District water-quality specialist or District-designated reviewer for completeness and accuracy.

\section{PUBLICATION}

It is the policy of the USGS that, with only a few exceptions, all data collected by the USGS are published or made publicly available. Although paper reports are the traditional means of publication, data currently (2000) are being made available in other electronic formats, such as computer disks, compact disks-read only to memory (CD-ROMs), or the World Wide Web. The same requirements for checking for completeness and accuracy of the record apply to all formats of publication.

\section{Data Reports}

All nonproprietary water-quality data collected during the water year are published in the USGS annual data report, "Water Resources Data, [State name], Water Year __, or in individual project data reports. Approval of hydrologic data reports is in accordance with applicable USGS policies (Alt and Iseri, 1986). USGS policy (U.S. Department of the Interior, 1992) states that data and information are to be published; however, publication is not limited to paper media (U.S. Geological Survey, 1990; U.S. Department of the Interior, 1993). Electronic formats for public distribution include computer storage media, such as CD-ROM and the World Wide Web. 


\section{Data Qualification Statements}

The accuracy of published water-quality monitoring records is described by the rating of the record and in the Publication Criteria section (table 9), and the accuracy attributed to the waterquality records is indicated in the REMARKS paragraph of the manuscript station description (Appendix 9). Different accuracies may be attributed to different parts of a given record.

\section{ARCHIVING OF RECORDS}

According to USGS policy, all original data that are published or support published scientific analyses are to be archived (Hubbard, 1992; U.S. Geological Survey, 1992). Original data-from automated datacollection sites, laboratories, outside sources, and nonautomated field observations - are unmodified data as collected or received and in conventional units (engineering units, generally with a decimal). Original data should be preserved in this form, no matter how they may be modified later (Hubbard, 1992). Recent USGS policy (U.S. Geological Survey, 1999) reaffirms the requirement of preserving original unaltered field data, and further requires that the data be preserved in computer-readable (electronic) digital format. In addition, paper copies of digital field-recorded timeseries data are no longer required. All personnel responsible for the collection, analysis, manipulation, and storage of water-quality monitoring data should ensure that the specified requirements of archiving original electronic data are implemented.

In addition to electronic field data, original water-quality monitoring data on paper may include field notes, field measurements, calibration notes. analytical service requests, and water-quality analytical printouts. These data are archived when the project is completed or terminated, or if data are more than 7 years old. It is the responsibility of the District Chief to ensure that project files are entered into the District archive and are organized and complete. The District archive is well documented and maintained by specified personnel in the District.

\section{SUMMARY}

Recording systems that measure physical and chemical water-quality properties at discrete time intervals provide a nearly continuous record of water quality. A common configuration is the four-property water-quality monitoring system that collects temperature, specific conductance, dissolved oxygen, and $\mathrm{pH}$ data, although systems can be configured to measure other properties such as turbidity or chlorophyll. The sensors that are used to measure these water properties require careful field observation, cleaning, and calibration. Producing an accurate final record requires thorough procedures for the computation, publication, and archiving of the data.

This report provides guidelines for U.S.

Geological Survey site-selection considerations, sensor test methods, field procedures, error correction, data computation, and review and publication processes. Emerging sensor technology is broadening the variety of measurable chemical constituents and will continue to lower the limits of detection. Recent improvements have been made in our ability to make near real-time water-quality monitoring data available through the World Wide Web. This progress will improve applications and allow quality-control procedures to be refined.

\section{SELECTED REFERENCES}

Alt, D.F., and Iseri, K.T., 1986, Water Resources Division publications guide, v. 1, Publications policy and text preparation: U.S. Geological Survey, Water Resources Division, 1986 ed., 429 p.

Bartholoma, S.D., comp., 1997. User's manual for the National Water Information System of the U.S. Geological Survey, chap. 3., Automated data processing system: U.S. Geological Survey Open-File Report 97-635, $219 \mathrm{p}$.

Busenberg, Eurybiades, and Plummer, L.N., 1987, pH measurement of low-conductivity waters: U.S. Geological Survey Water-Resources Investigations Report 87-4060, 22 p.

Christensen, V.G., Jian, X., and Ziegler, A.C., 2000, Regression analysis and real-time water-quality monitoring to estimate constituent concentrations, loads, and yields in the Little Arkansas River, SouthCentral Kansas, 1995-99: U.S. Geological Survey Water-Resources Investigations Report 00-4126, $36 \mathrm{p}$.

Clifton, D.G., and Gilliom, R.J., 1989, Sources and concentrations of dissolved solids and selenium in the San Joaquin River and its tributaries, California. October 1985 to March 1987: U.S. Geological Survey Water-Resources Investigations Report 88-4217, 33 p. 
Ficken, J.H., and Scott, C.T., 1989, Operating manual for the U.S. Geological Survey minimonitor-Analogvoltage model: U.S. Geological Survey Open-File Report 89-403, 55 p.

Gordon, A.B., and Katzenbach, Max, 1983, Guidelines for use of water-quality monitors: U.S. Geological Survey Open-File Report 83-681, 94 p.

Hem, J.D., 1989, Study and interpretation of the chemical characteristics of natural water: U.S. Geological Survey Water-Supply Paper 2254, 264 p.

Hill, B.R., and Gilliom, R.J., 1993, Streamflow, dissolved solids, suspended sediment, and trace elements, San Joaquin River, California, June 1985-September 1988: U.S. Geological Survey Water-Resources Investigations Report 93-4085, 21 p.

Hubbard, E.F., 1992, Policy recommendations for management and retention of hydrologic data of the U.S. Geological Survey: U.S. Geological Survey OpenFile Report 92-56, 32 p.

Novak, C.E., 1985, WRD data reports preparation guide: U.S. Geological Survey, Water Resources Division, 1985 ed., 289 p.

Radtke, D.B., Busenberg, Eurybiades, Wilde, F.D., and Kurklin, J.K., 1998, pH, in Wilde, F.D., and Radtke, D.B., eds.. 1998, Field measurements, in National field manual for the collection of water-quality data: U.S. Geological Survey Techniques of Water-Resources Investigations, book 9, chap. A6.4, 27 p.

Radtke, D.B., Davis, J.V., and Wilde, F.D., 1998, Specific electrical conductance, in Wilde, F.D., and Radtke, D.B., eds., 1998, Field measurements, in National field manual for the collection of water-quality data: U.S. Geological Survey Techniques of Water-Resources Investigations, book 9, chap. A6.3, 22 p.

Radtke, D.B., Kurklin, J.K., and Wilde, F.D., 1998. Temperature, in Wilde, F.D., and Radtke, D.B.. eds., 1998. Field measurements, in National field manual for the collection of water-quality data: U.S. Geological Survey Techniques of Water-Resources Investigations, book 9, chap. A6.1, 15 p.

Radtke, D.B., White, A.F., Davis, J.V., and Wilde, F.D., 1998, Dissolved oxygen, in Wilde. F.D., and Radtke. D.B., eds., 1998. Field measurements, in National field manual for the collection of water-quality data: U.S. Geological Survey Techniques of Water-Resources Investigations, book 9, chap. A6.2, 38 p.

Rantz, S.E., and others, 1982, Measurement and computation of streamflow: Volume 1. Measurement of stage and discharge: U.S. Geological Survey WaterSupply Paper 2175, 284 p.
Stanley, D.L., Boozer, T.M., and Schroder, L.J., 1998. Summary of the U.S. Geological Survey National Field Quality-Assurance Program from 1979 through 1997:

U.S. Geological Survey Open-File Report 98-392, 11 p.

U.S. Department of the Interior, 1992, Department of the Interior Geological Survey Manual, v. 3, 500.14.1, 3 p.

-1993, Department of the Interior Geological Survey Manual, v. 3, 500.24.1, 4 p.

U.S. Geological Survey, 1990, Policy for release of digital data: Water Resources Division Memorandum No. 90.30 [deleted], accessed August 14, 2000, at URL http://wwwoper.er.usgs.gov/memos/delete/ wrd90.030Delete.txt.

-1992, Policy for management and retention of hydrologic data of the U.S. Geological Survey: Water Resources Division Memorandum No. 92.59, accessed August 11, 2000, at URL http://water.usgs.gov/admin/ memo/WRD/wrd92.059.html.

1995. Transmittal of an instrumentation plan for the Water Resources Division and the Water Resources Division hydrologic field instrumentation and equipment policy and guidelines: Water Resources Division Memorandum No. 95-35, accessed August 8, 2000, at URL http://water.usgs.gov/public/admin/ memo/WRD/wrdpolicy95.035.html.

-1999. Preservation of original digital field-recorded time-series data: Water Resources Division Memorandum No. 99.33, accessed August 11, 2000. at URL http://water.usgs.gov/admin/memo/WRD/ wrd99.33.html.

Weiss, R.F., 1970. The solubility of nitrogen, oxygen, and argon in water and seawater: Deep Sea Research, v. 17. no. 4 , p. $721-735$.

White, E.T., comp., 1999, Automated water quality monitoring field manual: British Columbia, Canada, Ministry of the Environment Lands and Parks, Water Management Branch for the Aquatic Inventory Task Force Resources Inventory Committee, Version 1.0 [June 8, 1999], 61 p.

Wilde. F.D., and Radtke, D.B., eds.. 1998, Field measurements, in National field manual for the collection of water-quality data: U.S. Geological Survey Techniques of Water-Resources Investigations, book 9, chap. A6 [variously paged].

Wilde, R.F., and Gibs, Jacob, 1998. Turbidity, in Wilde, F.D., and Radtke, D.B., eds.. 1998. Field measurements, in National field manual for the collection of water-quality data: U.S. Geological Survey Techniques of WaterResources Investigations, book 9, chap. A6.7, 30 p. 


\section{Appendixes}


Appendix 1-Example for calculation of average $\mathrm{pH}$

\begin{tabular}{ll}
\hline & \multicolumn{1}{c}{ Converting to appropriate $\left[\mathrm{H}^{+}\right]$} \\
\hline \hline Daily maximum $\mathrm{pH}=8.0$ & $\mathrm{pH} 8.0=0.00000001\left[\mathrm{H}^{+}\right]$ \\
Daily minimum $\mathrm{pH}=6.0$ & $\mathrm{pH} 6.0=0.00000100\left[\mathrm{H}^{+}\right]$ \\
Average $\mathrm{pH}$ (inaccurate) $=7.0$ & Average $=0.000000505\left[\mathrm{H}^{+}\right]$ \\
\cline { 2 - 2 } & Average $($ correct $)=$ antilog $=\mathrm{pH}=6.32$ \\
\hline
\end{tabular}




\title{
Appendix 2-Station description
}

\section{Appendix 2A-Contents of a station description}

Specific information about a field site (station) is summarized in a station description. The description should include:

1. Location of station

2. Station history

3. Drainage area (including basin characteristics)

4. Station description, equipment, and benchmarks

5. Discharge and monitor measurements methods and historical extremes

6. Cross-section measurements (discharge and water-quality)

7. Purpose and cooperation

8. Maps, photographs, and permits

9. Safety hazards, detailed road log, and access remarks

\section{Appendix 2B-Example of a station description for the Columbia River at Beaver Army Terminal near Quincy, Oregon}

\author{
U.S. DEPARTMENT OF THE INTERIOR \\ GEOLOGICAL SURVEY \\ WATER RESOURCES DIVISION
}

Original prepared 12-23-91 by K.K. Lee revised 2-17-2000 by R.L.Kittelson

\section{Description of Gaging Station}

14-2469.00 Columbia River at Beaver Army Terminal nr Quincy, OR

LOCATION: Lat $46^{\circ} 10^{\prime} 55^{\prime \prime}$, Long $123^{\circ} 10^{\prime} 50^{\prime \prime}$, in NE1/4 sec 16, T.8 N., R.4 W., Columbia County, in an unused warehouse on $1600 \mathrm{ft}$ long dock operated and maintained by Portland General Electric.

HISTORY: Stage data collected May 1968 to June 1970, Feb. 1991 to present. Stork Servex Surflow Mark 4 UVM (Ultrasonic Velocity Meter) installed June 1991. ORE Accusonic Model 7300 UVM installed Apr. 1997.

DRAINAGE AREA: 256,900 sq mi.

GAGE ON DOCK (LEFT BANK): Stage and velocity sensing equipment housed in room at warehouse. Data is recorded on a Campbell Scientific CR 10X data logger. Data logger is connected to modem (phone number 503-728-2376). USGS computer downloads data from data logger on a daily schedule.

A. Stage: An 18 inch diameter corrugated pipe well is attached to a wood piling directly under the gage house floor. The top of the well is at approximately $20 \mathrm{ft}$ gage datum. The bottom of the well 
is capped and at elevation -1.0 ft gage datum. Several holes along the length of the well provide communication. An SDI-12 shaft encoder with float/tape system senses stage in the well and is recorded by the data logger. Range is -1.0 to $+14 \mathrm{ft}$. Gage is referred to an electric tape gage (index elevation $22.672 \mathrm{ft}$ gage datum, $23.192 \mathrm{ft}$ sea level, from levels of 9-15-99) on the instrument shelf, $\mathrm{RP1}$, or a staff gage $(0-13.5 \mathrm{ft})$ at the downstream end of the dock.

B. Velocity (Stork Servex Surflow Mark 4 UVM): Four transducers with a frequency of 100 KHZ are located in a crossed path configuration.

Left bank transducers are located on the upstream and downstream ends of the dock. Cables run under the dock surface and are wired directly into the UVM console. A junction box is located above high water near each transducer. Transducers are attached to an aluminum carriage that can be raised and lowered from the water surface. The carriages roll inside an aluminum channel track, which are bolted to the wooden dock pilings. The top of the upstream aluminum channel is at approximately $12 \mathrm{ft}$ gage datum, extends down to $-25.5 \mathrm{ft}$ gage datum, and the transducer is positioned at $-21 \mathrm{ft}$ gage datum. The top of the downstream aluminum channel is at approximately $10 \mathrm{ft}$ gage datum, extends down to $-27 \mathrm{ft}$ gage datum, and the transducer is positioned at $-25 \mathrm{ft}$ gage datum.

Right bank transducers are mounted on a 3 pile steel dolphin near the right bank, across the river from the dock. Transducer cables run up the piling to a responder, which relays signals received from the left bank transducers. There is no hard wire link across the channel. Transducers are attached to an aluminum carriage and can be raised and lowered from the water surface. Right bank transducer carriages roll along the face of the ' $\mathrm{H}$ ' piling. The top of the piling is at approximately $25 \mathrm{ft}$, and the bottom at $-35 \mathrm{ft}$. Total length at piling is $90 \mathrm{ft}$. These transducers are positioned at approximately $-25 \mathrm{ft}$ gage datum.

Path length and angles (determined 2-4-97):

Line 1: Upstream Oregon side. Length $=1906.4 \mathrm{ft}$, angle $=56.6^{\circ}$.

Line 2: Downstream Oregon side. Length $=1770.7 \mathrm{ft}$, angle $=69.9^{\circ}$.

Combined length $=3677.1 \mathrm{ft}$, combined angle $=$ at $63.3^{\circ}$.

C. Velocity (ORE Accusonic Model 7300 UVM): Two transducers, with a frequency of $200 \mathrm{khz}$, located inside the piling area of the $1600 \mathrm{ft}$ long dock, sense velocity in a 'short path'. Transducers are wired directly into the UVM console which is located in the gage house, cables are threaded through the underside of the dock. The UVM's SDI-12 output sends velocity data in feet per second to the CR10.

The upstream transducer is attached to shoreward side of dock piling, is located $160 \mathrm{ft}$ downstream of gage house (cable length $190 \mathrm{ft}$ ), and is aimed in a shoreward/downstream direction. The downstream transducer is attached to upstream dock piling on downstream end of dock, is located $450 \mathrm{ft}$ downstream and $250 \mathrm{ft}$ streamward (cable length $735 \mathrm{ft}$ ), and is aimed in a streamward/upstream direction. The angle of the transducers in relation to the dock is $33^{\circ}$, path length is $386 \mathrm{ft}$ (determined 4-10-97). Transducers are attached to 2 inch aluminum pipe which can be raised/lowered by sliding through pipe brackets, both transducers are positioned at approximately $-4.0 \mathrm{ft}$ gage datum. The transducer pipe brackets are accessible from a wood boardwalk which is below the road surface of the dock.

GAGE ON PILING (RIGHT BANK): Water temperature/conductance sensor and 2 transducers (Stork UVM) attached to 3 pile steel dolphin near right bank across from dock. CR 10X data logger, modem, cell phone (phone number 503-784-0136) and Stork Surflow UVM responder housed in a $1 \mathrm{ft} X 3 \mathrm{ft}$ X $4 \mathrm{ft}$ metal enclosure. Data logger records data from sensors. USGS computer downloads data from data logger on a daily schedule. 
A HIF temperature/conductance probe is mounted on the upstream piling near the right bank side, in the main flow on the Washington side of the River.

BENCH MARKS: Levels last run 9-15-99.

BM 6 - could not be found at time of levels on 9-15-99, consider it destroyed.

RM 1 - could not be found at time of levels on 9-15-99, consider it destroyed.

TBM 2 - head of a 5/8" carriage bolt which attaches the guard curb to the dock roadway near the gage. The bolt is $3 \mathrm{ft}$ streamward from the NW corner of the building which houses the gage, established 1966. Elevation $20.540 \mathrm{ft}$ gage datum, $21.060 \mathrm{ft}$ sea level. Used as the base RM for 9-15-99 levels.

RM 3 - NE corner (painted yellow) of square concrete pedestal of overhead light fixture $40 \mathrm{ft}$ shoreward and $5 \mathrm{ft}$ downstream from downstream corner of west end of dock, and $37 \mathrm{ft}$ shoreward of RM 4, established 9-15-99. Elevation $20.690 \mathrm{ft}$ gage datum, $21.210 \mathrm{ft}$ sea level, from 9-15-99 levels.

RM 4 - NE corner (painted yellow) of square concrete pedestal of overhead light fixture, $3 \mathrm{ft}$ shoreward and $5 \mathrm{ft}$ downstream from downstream corner of west end of dock, established 9-15-99. Elevation $21.205 \mathrm{ft}$ gage datum, $21.725 \mathrm{ft}$ sea level, from 9-15-99 levels.

RP 1 - head of $1 / 2$ inch lag bolt painted yellow in side of walkway $18 \mathrm{ft}$ downstream and $4 \mathrm{ft}$ shoreward of TBM 2, established 9-15-99. This RP can be used as a tape down to water surface. Elevation $19.423 \mathrm{ft}$ gage datum, 19.943 sea level, from 9-15-99 levels.

Datum of gage is $0.52 \mathrm{ft}$ above mean sea level.

DISCHARGE MEASUREMENTS: Made by Acoustic Doppler Current Profiler (ADCP) with boat at section $1000-1500 \mathrm{ft}$ downstream from gage, and just below dock. Hazards occur from floating debris, particularly at high flow. During low flow, measurement times should be coordinated with the tide cycle for steady flow.

FLOODS: Maximum daily discharge 864,000 cfs Feb. 10, 1996; maximum gage height 13.33 ft Feb. 9 , 1996.

POINT OF ZERO FLOW: Tide effect reverses flow during low-flow periods.

WINTER FLOW: No ice effect.

REGULATION: Flow regulated by many reservoirs in the basin.

ACCURACY: Measuring conditions are good except at extremely low velocities.

COOPERATION: U.S. Army Corps of Engineers, State of Oregon Department of Environmental Quality.

MAPS: Station can be located on Clatskanie, Oregon-Washington 15 minute 1952 USGS topographic sheet.

PHOTOGRAPHS: On file at Portland Field Office.

PERMITS: Permits from Corps of Engineers, Washington Department of Fisheries, Cowlitz County Washington, and Portland General Electric on file at Portland Field Office. 


\section{ROAD LOG:}

Columbia River at Beaver Army Terminal nr Quincy, OR 14-2469.00

\begin{tabular}{crl} 
Interval & Total & Local \\
\cline { 3 - 3 } 0.0 & 0.0 & Oregon Hwy 30 at Longview Bridge \\
3.7 & 3.7 & Alston Mayger Rd. Turn right. \\
0.2 & 3.9 & Intersection. Turn right in front of grocery store. \\
6.7 & 10.6 & Intersection Fish Station Rd. Continue on main road. \\
2.3 & 12.9 & Unmarked intersection. Turn right. \\
1.2 & 14.1 & Guard station. Check in. Go straight. \\
0.5 & 14.6 & Boat launch. \\
0.3 & 14.9 & Dock. Stilling well and AVM is in west end of large wood building. \\
& & Go through second door from west side.
\end{tabular}

Alternate route which goes through Clatskanie, recommended when towing large boat. This route is narrow and winding.

\begin{tabular}{|c|c|c|}
\hline 0.0 & 0.0 & $\begin{array}{l}\text { Downtown Clatskanie at intersection of Hwy } 30 \text { and Nehalem St. } \\
\text { Go north on Nehalem. }\end{array}$ \\
\hline 0.3 & 0.3 & Intersection of 5 th St. Turn left. \\
\hline 2.9 & 3.2 & Intersection unmarked. Turn left. \\
\hline 0.3 & 3.5 & Intersection Ritter Rd. Turn left. \\
\hline 0.8 & 4.3 & Downtown Quincy. Go straight. \\
\hline 1.0 & 5.3 & Quincy fire'station. Go straight. \\
\hline 0.3 & 5.6 & $\begin{array}{l}\text { Intersection unmarked. Turn left. This is same point on above road } \\
\log \text { at mile } 12.9 \text {. }\end{array}$ \\
\hline
\end{tabular}

rlk, 2-17-2000 


\section{Appendix 3-Station analysis}

\section{Appendix 3A-Contents of a station analysis}

Specific information about a field site (station) is summarized annually in a station analysis. The analysis should include:

1. Sampling location-Station, name, number, year, and constituent measure

2. Sampling equipment or instrumentation-Type of monitoring sensor(s) and recorder, location of sensor(s) or intakes, any other special instrumentation or features, and dates sensor(s) were changed or replaced.

3. Published records - State the constituent parameter that is published, as well as any data that is collected and not published.

4. Channel characteristics-Brief description of the composition of the channel and any unique or unusual features of the installation.

5. Rating - Statement as to how the digital record is interpreted to provide the published constituent values for the primary and final records.

6. Record-Statement of the completeness of the record. Note all missing data and include the final rating of accuracy for the period of record (or specific service intervals) in chronological order.

7. Calibration-State how and when the instrument was calibrated or checked and note the procedures used in the calibration process. Include statement if corrections were needed for the data.

8. Computations - Statement of how corrections were applied to the data, a list of extreme correction values that were applied to the recorded values during the year, and causes of the need for correction.

9. Treatment of atypical data-Any treatment of unusual or atypical data should be documented.

10. Cross-section measurements - State how and when the cross section was measured, the number of verticals, and the amount of variation throughout the cross section. State if the location of the sensor(s) or water-supply intake is representative of the stream.

11. Remarks - Any additional information about the site, data collected, or general statements that do not fit in any other section. 


\section{Appendix 3B-Example of a station analysis for temperature on the Columbia River at Beaver Army Terminal, near Quincy, Oregon}

1999

$14-2469.00$

\section{STATION ANALYSIS}

TEMPERATURE

Columbia River at Beaver Army Terminal, Near Quincy, Oregon

Equipment.-- Campbell CR 10X datalogger and HIF temperature/conductance probe located on the UVM transducer piling near the RB, in a section of the river with good velocities. On March 3, 1996 a cellphone system was installed that allows the site to be called daily between 1400 and 1430 to download data. Phone number is 503-784-0136.

Published records.--Daily maximum, minimum, and mean temperatures.

Primary Records.--Complete for the year.

Channel Characteristics.--The channel is approximately $1800 \mathrm{ft}$ wide with depths up to $100 \mathrm{ft}$, with a bedrock bottom. Bradbury slough enters the river 0.3 miles upstream of the gage from the left bank. Under certain flow and tidal regimes, the x-section may not be well mixed on the right or left bank sections.

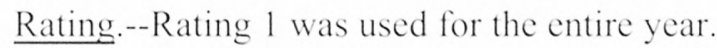

The measured temperature values ranged from $5.4{ }^{\circ} \mathrm{C}$ to $18.9^{\circ} \mathrm{C}$. The recorded temperature values ranged from $4.3^{\circ} \mathrm{C}$ to $21.9^{\circ} \mathrm{C}$.

Calibration.-- The HIF temperature/conductance probe values were checked using Hydrolab field instrument. Calibration checks for the Hydrolab instruments were made using a certified NBS mercury thermometer.

Calibration checks were performed, Feb. 19, 1997, Mar. 19, 1998, and July 9, 1999 for the small projects Hydrolab W489763, which indicated that no correction was needed. No corrections were made to data collected with this instrument.

Two calibration checks were performed on the Hydrolab W499764 (Oct. 21, 1997; Dec. 2, 1998), which indicated that no correction was needed. No corrections were made to data collected with this instrument.

In the $2000 \mathrm{WY}$, all Hydrolabs will be checked/logged on a more routine basis.

For the HIF temperature/conductance probe, no calibration is possible.

Cross-sectional measurements.-- The depth and width integrated cross-sections on Aug. 24, 1998 varied by $0.3{ }^{\circ} \mathrm{C}$. The depth and width integrated cross-sections on Sept. 14,1999 varied by $0.2{ }^{\circ} \mathrm{C}$. Width integrated cross-sections are made at the time of each NASQAN sampling. Cross-sectional data collected during sampling varied by less than $0.6{ }^{\circ} \mathrm{C}$.

Computations.--Recorded CR 10X values at the time of the cross-section are subtracted from the cross-section average, resulting in a computed correction to the recorded CR $10 \mathrm{X}$ values (cross-section - CR10X = correction). This method takes into account the variation between the 
CR 10X recorded values compared to the cross-section average, and also the difference between the CR10X readings compared to the reference instrument (Hydrolab). Corrections varied from $+0.2{ }^{\circ} \mathrm{C}$ to $-0.2^{\circ} \mathrm{C}$, and were applied on a time-prorated basis between visits. Corrections were used as follows:

DATE/TIME SHIFT

1998 LAST ST: $08241230 \quad-.10$

$11231210 \quad 0.10$

$01051130 \quad 0.10$

$01251140 \quad 0.00$

$02231120 \quad-0.20$

$03081200 \quad-0.20$

$03291140 \quad 0.10$

$04201050 \quad 0.10$

$05111120 \quad-0.10$

$05251110 \quad-0.10$

$06081120 \quad 0.10$

$06221100 \quad 0.10$

$09141120 \quad 0.20$

2000 FIRST ST: $10191130 \quad 0.20$

Treatment of Atypical Data.--None found.

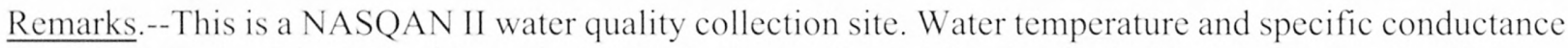
data are furnished monthly to the USGS in Reston for publication in the National Water Conditions report. No discharge was available at the time the record was computed.

Douglas O. Cushman, 12-17-1999

checked by

doc, 12-17-99

T.A. Herret $1 / 2 / 2000$ 
Appendix 4-U.S. Geological Survey water-quality monitor field-inspection form

U.S. GEOLOGICAL SURVEY, WRD

\section{WATER QUALITY FIELD INSPECTION FORM}

Sta. Name:

Sta. No.:

Observations Made By:

Date:

EDL Time Reset?

EDL Operational?

Program Altered?

Downloaded?

Remarks:
Watch Time:

Watch Time:

Battery Voltage Found:

Battery Replaced? No Yes

File Name:
EDL Time:

EDL Time:

Volts

Volts

$\begin{array}{ll}\text { No } & \text { Yes } \\ \text { No } & \text { Yes }\end{array}$

\section{EDL SENSOR SECTION}

\begin{tabular}{l|l|l|l|l|l}
\hline $\begin{array}{l}\text { Sensor } \\
\text { Name }\end{array}$ & $\begin{array}{l}\text { Std. } \\
\text { or } \\
\text { Field Meas. }\end{array}$ & $\begin{array}{l}\text { EDL } \\
\text { Initial } \\
@ \mathrm{~T}^{\circ}\end{array}$ & $\begin{array}{l}\text { EDL } \\
\text { Serviced } \\
@ \mathrm{~T}^{\circ}\end{array}$ & $\begin{array}{l}\text { EDL } \\
\text { Adjusted } \\
@ \mathrm{~T}^{\circ}\end{array}$ & $\begin{array}{l}\text { Sensor } \\
\text { Condition } \\
\text { (i.e... algae growth, silted) }\end{array}$ \\
\hline
\end{tabular}

\begin{tabular}{|l|l|}
\hline Stage & OG: \\
\hline W. T ${ }^{\circ} \mathrm{C}$ &
\end{tabular}

$\mathrm{SC}$

SC

$\mathrm{SC}$

$\mathrm{SC}$

$\mathrm{pH}$

$\mathrm{pH}$

$\mathrm{pH}$

$\mathrm{pH}$

DO

DO

DO

ZERO

Turbidity ZERO

Turbidity

@ $\mathrm{T}^{\circ}$

@ T

@ T

Cell:

Slope:

Offset:

Press:

$\mathrm{mm} / \mathrm{Hg}$

Salinity corr.:

Slope:

Offset:

Sensor(s) removed from water

Returned

HRMN 


\section{Sensor(s) Maintenance Comments:}

Weather: Clear Partly Cloudy Light Medium Heavy Snow Rain Calm Light Breeze

Gusty Wind Very Cold Warm Hot Snow on Ground? No Yes____in.

\begin{tabular}{|c|c|c|c|c|c|}
\hline Reference Meter(s) & Make/Model & Serial No. & \multicolumn{3}{|c|}{ Corr. factor applied? } \\
\hline Temperature & & & None & Yes & No \\
\hline Conductivity & & & None & Yes & $\mathrm{No}$ \\
\hline $\mathrm{pH}$ & & & None & Yes & No \\
\hline \multirow[t]{3}{*}{ Dissolved Oxygen } & & & None & Yes & No \\
\hline & & & None & Yes & No \\
\hline & & & None & Yes & No \\
\hline
\end{tabular}

\section{Control:}

Flow:

$\begin{array}{ll}\text { Cross Sectional Measurements: } & \text { Method: EDI, EWI, other } \\ & \text { Meas. Location: } \\ & \text { Stream Mixing: Excellent Good upstream downstream of monitor }\end{array}$

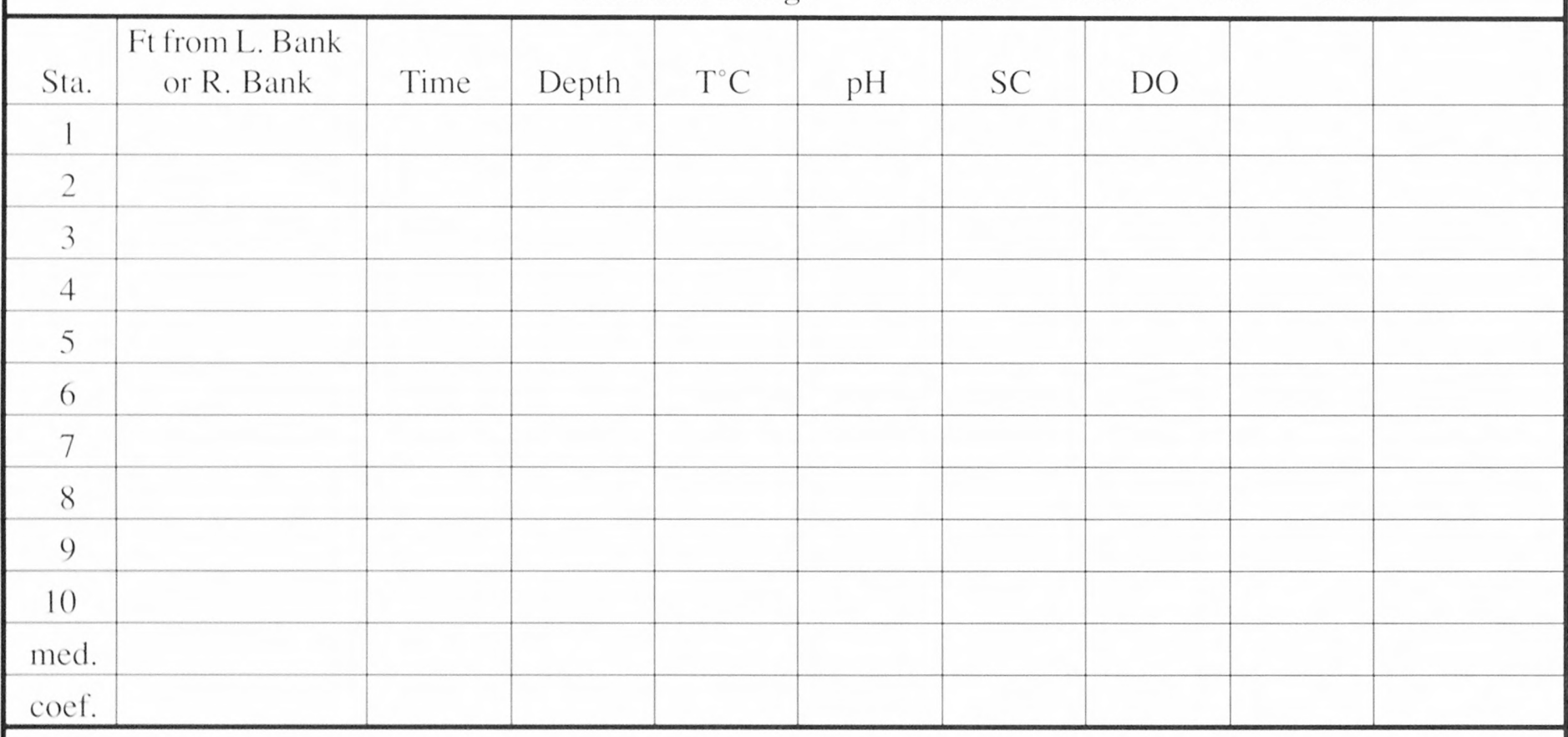

Observations: 
Appendix 5.-Effects of temperature on $\mathrm{pH}$ standards (refer to manufacturer's specifications)

$\left[{ }^{\circ} \mathrm{C}\right.$, degrees Celsius; all $\mathrm{pH}$ values are in standard $\mathrm{pH}$ units]

\begin{tabular}{cccc}
\hline \multirow{2}{*}{ Temp } & \multicolumn{3}{c}{ Buffer and nominal pH value } \\
\cline { 2 - 4 } & 4.01 & 7.00 & 10.00 \\
\hline 5 & 4.00 & 7.14 & 10.30 \\
10 & 4.00 & 7.10 & 10.23 \\
15 & 4.00 & 7.07 & 10.17 \\
20 & 4.00 & 7.04 & 10.11 \\
25 & 4.00 & 7.02 & 10.05 \\
30 & 4.01 & 7.00 & 10.00 \\
35 & 4.01 & 6.99 & 9.96 \\
40 & 4.02 & 6.98 & 9.92 \\
45 & 4.03 & 6.98 & 9.88 \\
50 & 4.05 & 6.98 & 9.85 \\
55 & 4.06 & 6.98 & 9.82 \\
60 & 4.07 & 6.98 & 9.79 \\
\hline
\end{tabular}


Appendix 6-Troubleshooting problems with water-quality monitors

\begin{tabular}{|c|c|c|}
\hline Symptom & Possible problem & Likely solution \\
\hline \multicolumn{3}{|c|}{ Water Temperature } \\
\hline $\begin{array}{l}\text { Thermistor does not read accu- } \\
\text { rately }\end{array}$ & Dirty sensor & Clean sensor \\
\hline Erratic monitor readings & $\begin{array}{l}\text { Poor connections at monitor or } \\
\text { sensor }\end{array}$ & Tighten connections \\
\hline Monitor slow to stabilize & Dirty sensors & Clean sensor \\
\hline Readings off scale & Failure in electronics & Replace sensor or monitor \\
\hline \multicolumn{3}{|c|}{ Specific electrical conductance } \\
\hline \multirow[t]{4}{*}{ Will not calibrate } & $\begin{array}{l}\text { Standards may be old or contami- } \\
\text { nated }\end{array}$ & Use fresh standards \\
\hline & Electrodes dirty & Clean with soap solution \\
\hline & Air trapped around sensor & $\begin{array}{l}\text { Thrust sensors up and down to } \\
\text { expel air }\end{array}$ \\
\hline & Weak batteries & Replace batteries \\
\hline \multirow[t]{2}{*}{ Erratic monitor readings } & Loose or defective connections & Tighten or replace \\
\hline & Broken cables & Replace cables \\
\hline $\begin{array}{l}\text { Monitor requires frequent cali- } \\
\text { bration }\end{array}$ & & Replace monitor \\
\hline \multicolumn{3}{|c|}{ Dissolved oxygen } \\
\hline \multirow[t]{3}{*}{$\begin{array}{l}\text { Meter drift or excessive time for } \\
\text { monitor to stabilize }\end{array}$} & $\begin{array}{l}\text { Temperature compensator has not } \\
\text { equilibrated with temperature } \\
\text { of stream }\end{array}$ & $\begin{array}{l}\text { Wait for temperature } \\
\text { equilibration }\end{array}$ \\
\hline & Fouled sensor & Clean or recondition \\
\hline & $\begin{array}{l}\text { Stirrer or pulse mechanism not } \\
\text { working properly }\end{array}$ & Replace \\
\hline \multirow[t]{2}{*}{ Erratic monitor readings } & $\begin{array}{l}\text { Bad connection at monitor or sen- } \\
\text { sor }\end{array}$ & Tighten connections \\
\hline & Fouled sensor & Clean or recondition \\
\hline \multirow[t]{3}{*}{ Monitor slow to stabilize } & Gold cathode tarnished & $\begin{array}{l}\text { Buff with ink eraser or } \\
\text { recondition sensor }\end{array}$ \\
\hline & Fouled membrane & $\begin{array}{l}\text { Recondition sensor and replace } \\
\text { membrane }\end{array}$ \\
\hline & Silver anode blackened & $\begin{array}{l}\text { Replace sensor and soak fouled } \\
\text { sensor in 3\% ammonia for } \\
24 \text { hours }\end{array}$ \\
\hline Monitor will not zero & $\begin{array}{l}\text { Zero-DO solution contains oxy- } \\
\text { gen }\end{array}$ & $\begin{array}{l}\text { Add additional sodium sulfite to } \\
\text { zero-DO solution }\end{array}$ \\
\hline \multirow[t]{2}{*}{ Monitor will not calibrate } & Membrane damaged & Replace membrane \\
\hline & Electrolyte diluted & $\begin{array}{l}\text { Replace membrane and } \\
\text { electrolyte }\end{array}$ \\
\hline
\end{tabular}




\section{Appendix 6-Troubleshooting problems with water-quality monitors-Continued}

\begin{tabular}{|c|c|c|}
\hline Symptom & Possible problem & Likely solution \\
\hline \multicolumn{3}{|c|}{$\mathrm{pH}$} \\
\hline \multirow[t]{2}{*}{ Meter will not calibrate } & Buffers may be contaminated & Replace buffers \\
\hline & Faulty sensor & Replace \\
\hline \multirow[t]{2}{*}{ Slow response time } & Dirty sensor bulb & Clean sensor \\
\hline & $\begin{array}{l}\text { Water is cold or low ionic } \\
\text { strength }\end{array}$ & Patience \\
\hline \multirow[t]{2}{*}{ Erratic readings } & Loose or defective connections & Tighten \\
\hline & Defective sensor & Replace sensor \\
\hline \multicolumn{3}{|c|}{ Turbidity } \\
\hline \multirow[t]{4}{*}{$\begin{array}{l}\text { Unusually high or erratic read- } \\
\text { ings }\end{array}$} & $\begin{array}{l}\text { Entrained air bubbles on the opti- } \\
\text { cal sensor. }\end{array}$ & $\begin{array}{l}\text { Follow manufacturer's direc- } \\
\text { tions }\end{array}$ \\
\hline & Damaged sensor & Replace sensor \\
\hline & Dirty sensor & $\begin{array}{l}\text { Clean following manufacturer's } \\
\text { directions }\end{array}$ \\
\hline & Water in connections & Dry connector and reinstall \\
\hline
\end{tabular}




\section{A Appendix 7-Example of an ADAPS primary data table}

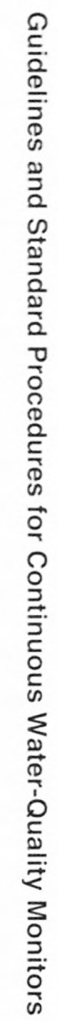

1 UNITED STATES DEPARTMENT OF INTERIOR - GEOLOGICAL SURVEY - WATER RESOURCES DIVISION STATE 53 DIST 53 PRIMARY COMPUTATIONS OF QUALITY OF WATER DIGITAL MONITOR RECORDS

12471400 DATE PROCESSED: 08-24-2000@11:23 BY kagreene

IDCOULE WASTEWAY AT SRI7 NR WARDEN. WA

(00010) WATER TEMPERATURE STORE STATISTIC $(S) 00001.00002 .00003$

PROVISIONAL. DATA FOR WATER YEAR ENDING SEPT. 30, 2000)

TEST DIFF:****** PUNCH INTERVAL: 60 MIN

VALUES AT INDICATED HOURS

\begin{tabular}{|c|c|c|c|c|c|c|c|c|c|c|c|c|c|c|c|c|}
\hline DATE & MAX & MIN & MEAN & & 1 & 2 & 3 & 4 & 5 & 6 & 7 & 8 & 9 & 10 & 11 & 1 \\
\hline \multirow[t]{2}{*}{$10-01$} & 14.3 & 12.4 & 13.5 & $\mathrm{AM}$ & 14.0 & 13.7 & 13.4 & 13.1 & 12.9 & 12.6 & 12.4 & 12.4 & 12.4 & 12.7 & 13.1 & 13.4 \\
\hline & & & & PM & 13.7 & 14.0 & 14.3 & 14.3 & 14.3 & 14.1 & 14.1 & 14.0 & 13.8 & 13.7 & 13.4 & 13.2 \\
\hline \multirow[t]{2}{*}{$10-02$} & 13.5 & 11.5 & 12.6 & $\mathrm{AM}$ & 13.1 & 12.7 & 12.6 & 12.3 & 12.1 & 11.8 & 11.7 & 11.5 & 11.7 & 11.8 & 12.1 & 12.6 \\
\hline & & & & PM & 12.9 & 13.2 & 13.4 & 13.5 & 13.4 & 13.4 & 13.2 & 13.1 & 12.9 & 12.7 & 12.4 & 12.3 \\
\hline \multirow[t]{2}{*}{$10-03$} & 13.2 & 10.9 & 12.2 & $\mathrm{AM}$ & 12.1 & 11.8 & 11.7 & 11.5 & 11.2 & 11.0 & 10.9 & 10.9 & 10.9 & 11.2 & 11.7 & 12.1 \\
\hline & & & & PM & 12.6 & 12.9 & 13.1 & 13.2 & 13.2 & 13.2 & 13.1 & 12.9 & 12.9 & 12.7 & 12.6 & 12.4 \\
\hline \multirow[t]{2}{*}{$10-04$} & 13.4 & 10.9 & 12.3 & $\mathrm{AM}$ & 12.1 & 12.0 & 11.8 & 11.5 & 11.3 & 11.2 & 11.0 & 10.9 & 11.0 & 11.3 & 11.8 & 12.1 \\
\hline & & & & PM & 12.6 & 12.9 & 13.2 & 13.4 & 13.4 & 13.2 & 13.2 & 13.1 & 13.1 & 12.9 & 12.9 & 12.7 \\
\hline \multirow[t]{2}{*}{$10-05$} & 14.0 & 12.0 & 13.0 & $\mathrm{AM}$ & 12.6 & 12.6 & 12.4 & 12.3 & 12.1 & 12.1 & 12.0 & 12.0 & 12.1 & 12.4 & 12.7 & 13.2 \\
\hline & & & & PM & 13.5 & 13.7 & 13.8 & 14.0 & 14.0 & 13.8 & 13.8 & 13.8 & 13.8 & 13.7 & 13.5 & 13.5 \\
\hline \multirow[t]{2}{*}{$10-06$} & 14.6 & 12.7 & 13.7 & $\mathrm{AM}$ & 13.4 & 13.4 & 13.2 & 13.1 & 12.9 & 12.7 & 12.7 & 12.7 & 12.7 & 13.1 & 13.4 & 13.8 \\
\hline & & & & PM & 14.1 & 14.3 & 14.6 & 14.6 & 14.6 & 14.4 & 14.4 & 14.3 & 14.1 & 14.0 & 13.8 & 13.7 \\
\hline \multirow[t]{2}{*}{$10-07$} & 14.0 & 12.7 & 13.5 & $\mathrm{AM}$ & 13.5 & 13.4 & 13.2 & 13.1 & 12.9 & 12.7 & 12.7 & 12.7 & 12.7 & 12.9 & 13.1 & 13.5 \\
\hline & & & & PM & 13.7 & 13.8 & 14.0 & 14.0 & 14.0 & 14.0 & 14.0 & 14.0 & 14.0 & 13.8 & 13.7 & 13.7 \\
\hline \multirow[t]{2}{*}{$10-08$} & 14.0 & 13.2 & 13.6 & $\mathrm{AM}$ & 13.7 & 13.7 & 13.5 & 13.5 & 13.4 & 13.4 & 13.2 & 13.2 & 13.4 & 13.4 & 13.7 & 13.8 \\
\hline & & & & PM & 14.0 & 14.0 & 14.0 & 14.0 & 13.8 & 13.8 & 13.7 & 13.7 & 13.5 & 13.5 & 13.4 & 13.2 \\
\hline \multirow[t]{2}{*}{$10-09$} & 13.5 & 12.1 & 12.8 & $\mathrm{AM}$ & 13.1 & 12.9 & 12.7 & 12.6 & 12.4 & 12.3 & 12.1 & 12.1 & 12.1 & 12.3 & 12.6 & 12.9 \\
\hline & & & & PM & 13.2 & 13.5 & 13.5 & 13.5 & 13.5 & 13.4 & 13.2 & 13.1 & 12.9 & 12.6 & 12.4 & 12.1 \\
\hline \multirow[t]{2}{*}{$10-10$} & 12.4 & 10.7 & 11.8 & $\mathrm{AM}$ & 12.0 & 11.8 & 11.7 & 11.3 & 11.2 & 10.9 & 10.7 & 10.7 & 10.7 & 10.9 & 11.3 & 11.7 \\
\hline & & & & PM & 12.0 & 12.3 & 12.4 & 12.4 & 12.4 & 12.4 & 12.4 & 12.4 & 12.4 & 12.4 & 12.4 & 12.3 \\
\hline \multirow[t]{2}{*}{$10-11$} & 12.4 & 11.7 & 12.1 & $\mathrm{AM}$ & 12.1 & 12.1 & 12.0 & 12.0 & 11.8 & 11.8 & 11.7 & 11.7 & 11.7 & 11.8 & 12.1 & 12.1 \\
\hline & & & & PM & 12.3 & 12.3 & 12.4 & 12.4 & 12.4 & 12.4 & 12.4 & 12.4 & 12.4 & 12.3 & 12.3 & 12.3 \\
\hline \multirow[t]{2}{*}{$10-12$} & 13.7 & 11.8 & 12.7 & $\mathrm{AM}$ & 12.1 & 12.1 & 12.0 & 12.0 & 12.0 & 11.8 & 11.8 & 11.8 & 11.8 & 12.1 & 12.4 & 12.9 \\
\hline & & & & PM & 13.2 & 13.5 & 13.7 & 13.7 & 13.7 & 13.7 & 13.5 & 13.5 & 13.4 & 13.4 & 13.2 & 13.1 \\
\hline \multirow[t]{2}{*}{$10-13$} & 14.4 & 12.3 & 13.3 & $\mathrm{AM}$ & 12.9 & 12.9 & 12.7 & 12.6 & 12.4 & 12.3 & 12.3 & 12.3 & 12.4 & 12.7 & 13.2 & 13.7 \\
\hline & & & & PM & 13.8 & 14.1 & 14.4 & 14.4 & 14.3 & 14.3 & 14.0 & 13.8 & 13.5 & 13.4 & 13.2 & 13.1 \\
\hline \multirow[t]{2}{*}{$10-14$} & 13.1 & 11.3 & 12.1 & $\mathrm{AM}$ & 12.9 & 12.6 & 12.4 & 12.1 & 12.0 & 11.7 & 11.5 & 11.3 & 11.5 & 11.5 & 11.8 & 12.1 \\
\hline & & & & PM & 12.4 & 12.6 & 12.7 & 12.7 & 12.6 & 12.4 & 12.3 & 12.0 & 11.8 & 11.7 & 11.5 & 11.3 \\
\hline \multirow[t]{2}{*}{$10-15$} & 11.3 & 9.8 & 10.6 & $\mathrm{AM}$ & 11.2 & 11.0 & 10.7 & 10.6 & 10.4 & 10.1 & 9.9 & 9.8 & 9.9 & 10.1 & 10.4 & 10.7 \\
\hline & & & & PM & 11.0 & 11.2 & 11.2 & 11.0 & 11.0 & 10.9 & 10.9 & 10.7 & 10.6 & 10.4 & 10.3 & 10.1 \\
\hline \multirow[t]{2}{*}{$10-16$} & 10.6 & 8.7 & 9.8 & $\mathrm{AM}$ & 9.9 & 9.8 & 9.6 & 9.3 & 9.2 & 9.0 & 8.7 & 8.7 & 8.7 & 9.0 & 9.3 & 9.6 \\
\hline & & & & PM & 10.1 & 10.3 & 10.6 & 10.6 & 10.6 & 10.6 & 10.4 & 10.3 & 10.3 & 10.1 & 10.1 & 9.9 \\
\hline $10-17$ & 10.9 & 9.0 & 10.0 & $\mathrm{AM}$ & 9.8 & 9.6 & 9.5 & 9.3 & 9.2 & 9.0 & 9.0 & 9.0 & 9.0 & 9.2 & 9.6 & 9.9 \\
\hline
\end{tabular}



PRIMARY COMPUTATIONS OF QUALITY OF WATER DIGITAL MONITOR RECORDS

12471400

DATE PROCESSED: 08-24-2000@11:23 BY kagreene

LIND COULEE WASTEWAY AT SR 17 NR WARDEN, WA

(00010) WATER TEMPERATURE STORE STATISTIC(S) 00001,00002,00003

PROVISIONAL DATA FOR WATER YEAR ENDING SEPT. 30, 2000

TEST DIFF:****** PUNCH INTERVAL: $60 \mathrm{MIN}$

VALUES AT INDICATED HOURS

\begin{tabular}{|c|c|c|c|c|c|c|}
\hline DATE & MAX & MIN & MEAN & & 1 & 2 \\
\hline \multirow[t]{2}{*}{$10-18$} & 11.3 & 9.5 & 10.5 & $\mathrm{AM}$ & 10.6 & 10.3 \\
\hline & & & & PM & 10.9 & 11.2 \\
\hline \multirow[t]{2}{*}{$10-19$} & 11.2 & 9.3 & 10.4 & $\mathrm{AM}$ & 10.6 & 10.3 \\
\hline & & & & PM & 10.7 & 10.9 \\
\hline \multirow[t]{2}{*}{$10-20$} & 11.2 & 9.3 & 10.4 & $\mathrm{AM}$ & 10.4 & 10.3 \\
\hline & & & & PM & 10.7 & 11.0 \\
\hline \multirow[t]{2}{*}{$10-21$} & 11.2 & 9.3 & 10.4 & $\mathrm{AM}$ & 10.4 & 10.3 \\
\hline & & & & PM & 10.6 & 10.9 \\
\hline \multirow[t]{2}{*}{ 10-22 } & 11.3 & 9.5 & 10.5 & $\mathrm{AM}$ & 10.4 & 10.3 \\
\hline & & & & PM & 10.9 & 11.2 \\
\hline \multirow[t]{2}{*}{ 10-23 } & 11.2 & 9.6 & 10.6 & $\mathrm{AM}$ & 10.4 & 10.4 \\
\hline & & & & PM & 10.9 & 11.0 \\
\hline
\end{tabular}

$\begin{array}{llll}5 & 6 & 7 & 8\end{array}$

9.9
11.3
9.9
11.2
9.9
11.2
9.9
11.2
9.9
11.3
10.1
11.2

\begin{tabular}{ll}
\multicolumn{1}{r}{$\quad$} & \multicolumn{1}{c}{5} \\
9.8 & 9.6 \\
11.3 & 11.3 \\
9.6 & 9.5 \\
11.2 & 11.0 \\
9.8 & 9.6 \\
11.0 & 11.0 \\
9.6 & 9.6 \\
11.2 & 11.0 \\
9.8 & 9.6 \\
11.3 & 11.2 \\
9.9 & 9.8 \\
11.2 & 11.2
\end{tabular}

$\quad 7$
9.5
11.2
9.3
11.0
9.5
10.9
9.3
11.0
9.5
11.2
9.6
11.2

9.5
11.0
9.3
10.9
9.3
10.9
9.3
10.9
9.5
11.0
9.6
11.2

\begin{tabular}{lr}
\multicolumn{1}{r}{9} \\
9.5 \\
11.0 \\
9.3 \\
10.7 \\
9.3 \\
10.7 \\
9.3 \\
10.9 \\
9.6 \\
11.0 \\
9.6 \\
11.2
\end{tabular}

10

$11 \quad 12$ $\begin{array}{lll}9.8 & 10.1 & 10.6\end{array}$ $\begin{array}{lll}0.9 & 10.7 \quad 10.6\end{array}$ 


\section{Appendix 8-Variable shift corrections}

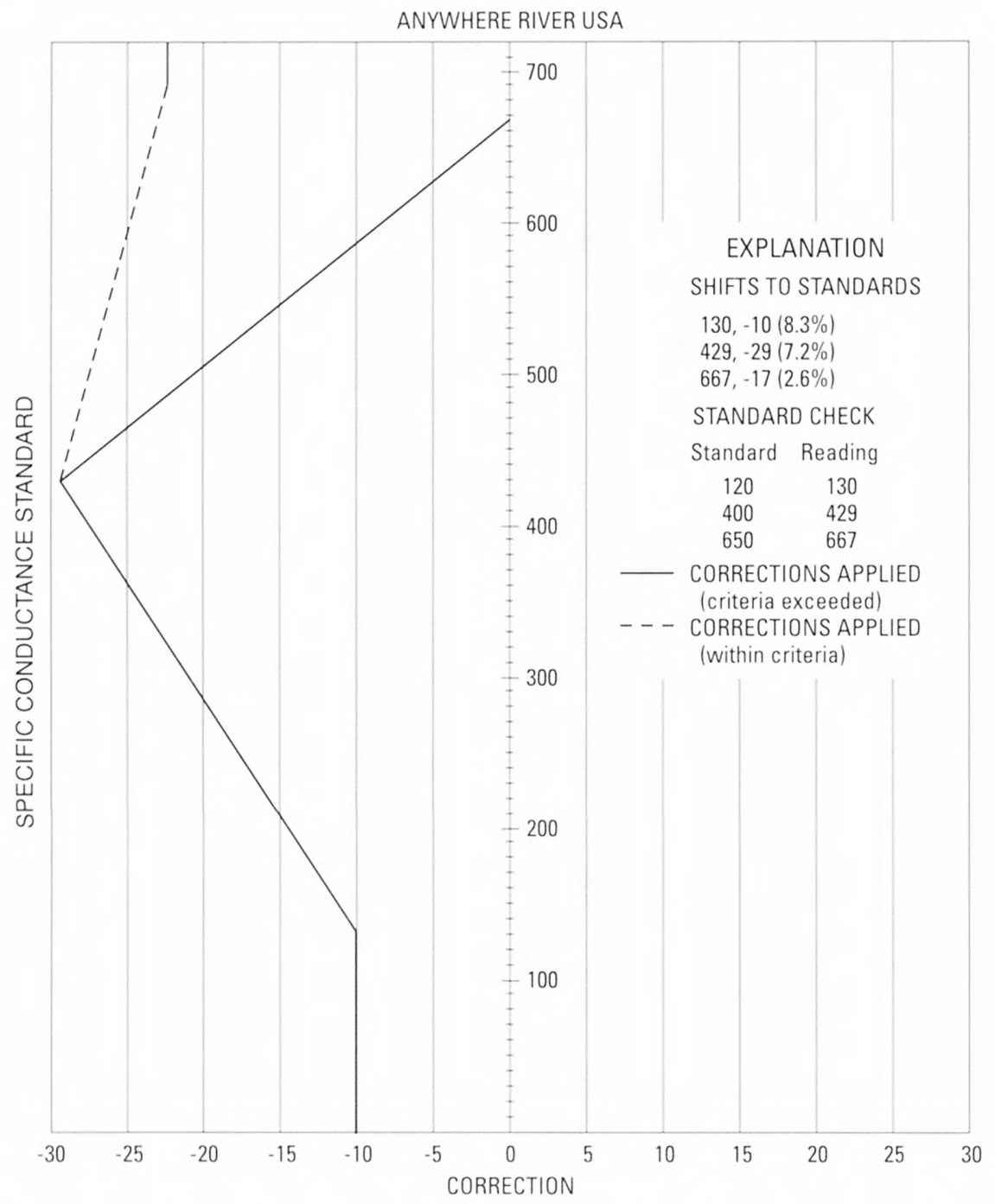




\section{NOOKSACK RIVER BASIN}

\section{FISHTRAP CREEK AT FLYNN ROAD, AT LYNDEN, WA}

LOCATION-Lat 48 55'36", long $122^{\circ} 29^{\prime} 42^{\prime \prime}$, in NW 1/4 SE 1/4 sec.25, T.40 N., R.2 E., Whatcom County, Hydrologic Unit 17110004 , on left bank, and at mile 1.7.

DRAINAGE AREA-38.1 mi2.

PERIOD OF RECORD-March 1996 to April 1998 (discontinued).

PERIOD OF DAILY RECORD-

SPECIFIC CONDUCTANCE: March to current year.

WATER TEMPERATURE: March to current year.

DISSOLVED OXYGEN: March to September 1996.

INSTRUMENTATION-Water-quality monitor since March 1996. Electronic data logger with 15 minute recording interval.

REMARKS - Specific conductance records rated excellent except the following periods: Dec. 13-Jan. 15, Aug. 5-31 rated good; Feb. 15-Mar. 10 rated fair; and Oct. 11-15 rated poor. Temperature records rated excellent.

\section{EXTREMES FOR PERIOD OF RECORD-}

SPECIFIC CONDUCTANCE: Maximum recorded, 337 microsiemens Nov. 19, 20, 1996, but may have been higher during period of missing record; minimum recorded, 108 microsiemens Jan. 30, 1997, but may have been lower during periods of missing record.

WATER TEMPERATURE: Maximum recorded, 20.5 C July 14, 26, 27, 29, 1996; minimum recorded, 0.0 $0^{\circ} \mathrm{C}$ Dec. 26-31, 1996.

DISSOLVED OXYGEN: Maximum recorded, $12.1 \mathrm{mg} / \mathrm{L}$ Mar. 24, 1996, but may have been higher during periods of missing record; minimum recorded, $7.1 \mathrm{mg} / \mathrm{L}$ July 27, Aug. 26, 1996, but may have been lower during periods of missing record.

\section{EXTREMES FOR CURRENT YEAR-}

SPECIFIC CONDUCTANCE: Maximum recorded, 337 microsiemens Nov. 19, 20, but may have been higher during period of missing record; minimum recorded, 108 microsiemens. Jan. 30, but may have been lower during period of missing record.

WATER TEMPERATURE: Maximum recorded, $19.0^{\circ} \mathrm{C}$ Aug. 13,14 , but may have been higher during period of missing record; minimum recorded, $0.0^{\circ} \mathrm{C}$ Dec. $26-31$. 
Station Name

COLUMBIA RIVER at BEAVER ARMY TERMINAL nr QUINCY, OREGON

No.

\begin{tabular}{|c|c|c|c|c|c|c|c|c|c|}
\hline \multirow[b]{2}{*}{ Date } & \multirow[b]{2}{*}{ Time } & \multicolumn{2}{|c|}{ Stream reading } & \multicolumn{3}{|c|}{ Cleaning and calibration check } & \multirow{2}{*}{$\begin{array}{c}\text { Datum } \\
\text { correction } \\
\text { Shift to } \\
\text { cross } \\
\text { section }\end{array}$} & \multirow{2}{*}{$\begin{array}{c}\begin{array}{c}\text { Variable } \\
\text { shift }\end{array} \\
\text { Shift to } \\
\text { STDS }\end{array}$} & \multirow[b]{2}{*}{ Remarks } \\
\hline & & $\begin{array}{l}\text { Recording } \\
\text { instrument }\end{array}$ & $\begin{array}{l}\text { Portable } \\
\text { field } \\
\text { unit }\end{array}$ & $\begin{array}{l}74 \text { STD/ } \\
\text { RDNG }\end{array}$ & $\begin{array}{l}147 \text { STD/ } \\
\text { RDNG }\end{array}$ & $\begin{array}{l}220 \text { STD/ } \\
\text { RDNG }\end{array}$ & & & \\
\hline \multirow[t]{3}{*}{ Aug. 27} & $10: 34$ & $\begin{array}{l}155.7 \\
154 / 10: 00 \\
156 / 10: 30\end{array}$ & 139 & & & & & $\begin{array}{l}91,-17 \\
161,-14 \\
231,-11\end{array}$ & $\begin{array}{l}\text { Before cleaning }(156) \text { - after } \\
\text { cleaning }(137)=-19=\text { cleaning } \\
\text { correction }\end{array}$ \\
\hline & $11: 01$ & $\begin{array}{l}137 \\
137 / 11: 00 \\
136 / 11: 30\end{array}$ & 139 & 72 & 142 & 212 & & $\begin{array}{l}72,+2 \\
142,+5 \\
212,+8\end{array}$ & \\
\hline & $12: 30$ & $\begin{array}{l}\text { 136/12:00 } \\
136 / 12: 30\end{array}$ & $\begin{array}{l}(138 * / \\
11: 26)\end{array}$ & & & & $\mathrm{DC}=-2$ & & $\begin{array}{l}\text { Cross section }(136) \text { - used RB } \\
\text { surface reading of }\left(138^{*}\right) \text { for } \\
\text { reading at probe }=-2=\text { DC }\end{array}$ \\
\hline \multicolumn{10}{|c|}{1997 Water Year } \\
\hline \multirow[t]{3}{*}{ Oct. 23} & $10: 20$ & $\begin{array}{l}130 \\
130 / 10: 00 \\
\mathrm{NA} / 10: 30\end{array}$ & & & & & & $\begin{array}{l}76,-2 ; \\
146,+1 \\
215,+5\end{array}$ & $\begin{array}{l}\text { Before cleaning }(130) \text { - after } \\
\text { cleaning }(126)=-4=\text { cleaning } \\
\text { correction }\end{array}$ \\
\hline & $10: 55$ & $\begin{array}{l}126 \\
126 / 11: 00 \\
125 / 11: 30\end{array}$ & 131 & 72 & $\begin{array}{l}141+143 \\
=142=\text { avg }\end{array}$ & 211 & & $\begin{array}{l}72,+2 \\
142,+5 \\
211,+9\end{array}$ & $\begin{array}{l}\text { Two different standards were used } \\
\text { and results were averaged }\end{array}$ \\
\hline & $12: 10$ & $\begin{array}{l}125 / 12: 00 \\
126 / 12: 30 \\
126 / 13: 00\end{array}$ & $\begin{array}{l}(130.5 * / \\
11: 22)\end{array}$ & & & & $\mathrm{DC}=0$ & & $\begin{array}{l}\text { Cross section (130) - used RB } \\
\text { surface reading of }\left(130^{*}\right) \text { for } \\
\text { reading at probe }=0=\mathrm{DC}\end{array}$ \\
\hline
\end{tabular}

Copied by:

Checked by:

Date:

$6 / 11 / 98$ 


\section{Appendix 11-Example of a variable shift correction table}

\section{VARIABLE SHIFT VALUES}

\section{AGENCY CODE: USGS \\ WATER YEAR: 1999}

STATION ID: 12113390

STATION NAME: DUWAMISH R AT GOLF COURSE AT TUKWILA, WA DATA DESCRIPTION: SPECIFIC CONDUCTANCE FROM EDL, IN US/CM @ 25C 1998 LAST SV:

$\begin{array}{cccccccc}* * * 2000 \text { FIRST SV: } \overline{10} \overline{12} \overline{1413} & 49.0 & .0 & 255.0 & & .0 & 498.0 & .0 * * * \\ \text { DATE/TIME } & \text { INPUT } & \text { SHIFT } & \text { INPUT } & \text { SHIFT } & \text { INPUT } & \text { SHIFT } \\ \text { MM DD/TTTT } & & & & & & \\ 10151300 & 52.00 & -3.00 & 255.00 & 0.00 & 498.00 & 0.00 \\ 12151135 & 52.00 & -3.00 & 255.00 & 0.00 & 498.00 & 0.00 \\ 01131116 & 51.00 & -2.00 & 255.00 & 0.00 & 498.00 & 0.00 \\ 01131127 & 52.00 & -3.00 & 255.00 & 0.00 & 498.00 & 0.00 \\ 02121116 & 49.00 & 0.00 & 255.00 & 0.00 & 498.00 & 0.00 \\ 03151205 & 49.00 & 0.00 & 255.00 & 0.00 & 498.00 & 0.00 \\ 04131114 & 53.00 & -4.00 & 255.00 & 0.00 & 498.00 & 0.00 \\ 04131122 & 55.00 & -6.00 & 255.00 & 0.00 & 498.00 & 0.00 \\ 05121305 & 44.00 & 5.00 & 255.00 & 0.00 & 498.00 & 0.00 \\ 05121313 & 49.00 & 0.00 & 255.00 & 0.00 & 498.00 & 0.00\end{array}$


Appendix 12-Example of a datum shift correction table

DATUM CORRECTION VALUES

\author{
DATUM CORRECTION VALUES \\ AGENCY CODE: USGS WATER YEAR: 1999 \\ STATION ID: 12113390 \\ STATION NAME: DUWAMISH R AT GOLF COURSE AT TUKWILA, WA \\ DATA DESCRIPTION: SPECIFIC CONDUCTANCE FROM EDL, IN US/CM@25C \\ 1998 LAST DC: \\ 2000 FIRST DC: $10121345-20.0$
}

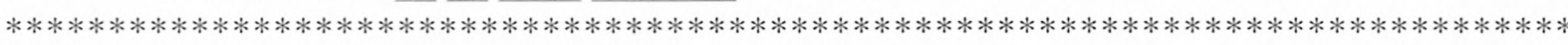

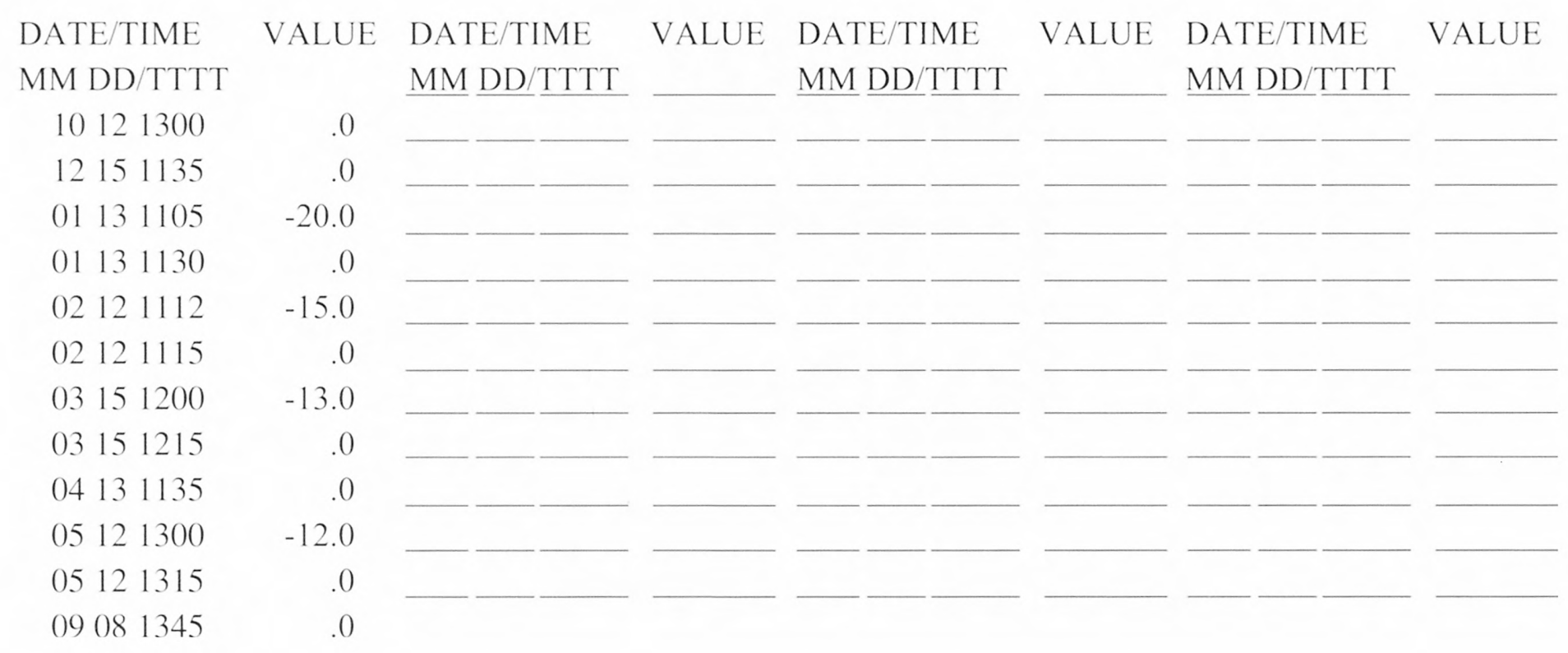




\section{Appendix 13-Example of an ADAPS daily-values table}

UNITED STATES DEPARTMENT OF THE INTERIOR - GEOLOGICAL SURVEY - WASHINGTON STATE NWIS 10/31/2000

STATION NUMBER 12113390 DUWAMISH R AT GOLF COURSE AT TUKWILA. WA STREAM SOURCE AGENCY USGS LATITUDE 472845 LONGITUDE 1221527 DRAINAGE AREA 461 DATUM STATE 53 COUNTY 033

FROM EDL

SPECIFIC CONDUCTANCE (MICROSIEMENS/CM AT 25 DEG. C), WATER YEAR OCTOBER 1998 TO SEPTEMBER 1999

DAY MAX MIN MEAN MAX MIN MEAN MAX MIN MEAN MAX MIN MEAN

OCTOBER

$\begin{array}{rrr}236 & 180 & 196 \\ 289 & 181 & 199 \\ --- & 162 & -- \\ 325 & 156 & 182 \\ 316 & 157 & 184\end{array}$

$184 \quad---1$

-- 189

-- 192

241

230

286

325

189

157

227

171

165

$170 \quad 200$

$184 \quad 212$

$147 \quad 165$

$142 \quad 149$

$149 \quad 160$

$223 \quad 151 \quad 165$

$\begin{array}{lll}227 & 151 & 172\end{array}$

175

177

175

147

147

139

161

158

20

21

22

23

24

25

$\begin{array}{llll}26 & 193 & 149 & 162\end{array}$

$\begin{array}{llll}27 & 285 & 150 & 177\end{array}$

$\begin{array}{llll}28 & 163 & 130 & 144\end{array}$

$\begin{array}{llll}29 & 227 & 147 & 167\end{array}$

$\begin{array}{llll}30 & 266 & 145 & 165\end{array}$

$\begin{array}{llll}31 & 328 & 143 & 171\end{array}$

MONTH
NOVEMBER

$\begin{array}{lll}259 & 141 & 158 \\ 244 & 140 & 152 \\ 278 & 141 & 160 \\ 280 & 135 & 173 \\ 135 & 112 & 124\end{array}$

$\begin{array}{lll}248 & 126 & 147\end{array}$

237

301

143

-- 136

$\begin{array}{rrr}-- & 131 & -- \\ 201 & 125 & 142\end{array}$

$\begin{array}{lll}143 & 82 & 108\end{array}$

$\begin{array}{lll}94 & 59 & 79\end{array}$

$\begin{array}{lll}59 & 56 & 57\end{array}$

$\begin{array}{lll}58 & 55 & 57\end{array}$

$66 \quad 57$

$73 \quad 64$

77

78

$\begin{array}{ll}78 & 76\end{array}$

76

63

60

59

$$
63
$$

$63 \quad 58$

$61 \quad 59$

$60 \quad 56$

$59 \quad 57$

$64 \quad 58$

-.-
DECEMBER

$\begin{array}{lll}78 & 63 & 73 \\ 78 & 74 & 76 \\ 78 & 75 & 76 \\ 75 & 70 & 72 \\ 76 & 70 & 74\end{array}$

76

77

77$$
84
$$$$
90
$$

$$
89
$$

82

75

64

69

$$
73
$$

74

74

77

81

$79 \quad 85$

75

60

60

60
59

$$
64
$$

71

67

72

73

$60 \quad 62$

64

61

62

66

\begin{abstract}
76
\end{abstract}

$$
93
$$

94

100

66

68

81

79

74

80

79

64

55

48

45

74
64
55
45
44
4

100

43

55

-..

(2)
JANUARY

$\begin{array}{lll}49 & 41 \quad 43\end{array}$

$\begin{array}{lll}44 & 37 & 40\end{array}$

$\begin{array}{lll}42 & 38 & 39\end{array}$

$\begin{array}{lll}49 & 40 & 44\end{array}$

$\begin{array}{lll}57 & 49 & 53\end{array}$

$\begin{array}{lll}63 & 56 & 59\end{array}$

$\begin{array}{lll}71 & 58 & 64\end{array}$

$\begin{array}{lll}70 & 66 & 68\end{array}$

$\begin{array}{lll}74 & 69 & 72\end{array}$

$\begin{array}{lll}75 & 72 & 74\end{array}$

$\begin{array}{lll}76 & 73 & 74\end{array}$

$\begin{array}{lll}74 & 63 & 67\end{array}$

$64 \quad 55 \quad 61$

$\begin{array}{lll}71 & 62 & 64\end{array}$

$73-2.95-10$

$\begin{array}{lll}84 & 73 \quad 80\end{array}$

$\begin{array}{lll}94 & 84 & 90\end{array}$

$\begin{array}{lll}97 & 94 & 95\end{array}$

$\begin{array}{lll}103 & 97 \quad 99\end{array}$

$\begin{array}{lll}105 & 103 \quad 104\end{array}$

$\begin{array}{lll}112 & 105 & 108\end{array}$

$113 \quad 110 \quad 111$

$110 \quad 109 \quad 110$

$111 \quad 110 \quad 110$

$113 \quad 111 \quad 112$

$119 \quad 113 \quad 115$

$124 \quad 119 \quad 121$

$\begin{array}{lll}126 & 120 \quad 124\end{array}$

$\begin{array}{lll}120 & 114 & 117\end{array}$

$\begin{array}{lll}115 & 114 & 115\end{array}$

$\begin{array}{lll}118 & 115 \quad 117\end{array}$

$\begin{array}{lll}126 & 37 \quad 85\end{array}$ 


\section{Appendix 13-Example of an ADAPS daily-values table (Continued)}

UNITED STATES DEPARTMENT OF THE INTERIOR - GEOLOGICAL SURVEY - WASHINGTON STATE NWIS 10/31/2000 STATION NUMBER 12113390 DUWAMISH R AT GOLF COURSE AT TUKWILA, WA STREAM SOURCE AGENCY USGS LATITUDE 472845 LONGITUDE 1221527 DRAINAGE AREA 461 DATUM STATE 53 COUNTY 033 FROM EDL

SPECIFIC CONDUCTANCE (MICROSIEMENS/CM AT 25 DEG. C), WATER YEAR OCTOBER 1998 TO SEPTEMBER 1999

\begin{tabular}{|c|c|c|c|c|c|c|c|c|c|c|c|c|}
\hline DAY & MAX & MIN & MEAN & MAX & MIN & MEAN & MAX & MIN & MEAN & MAX & MIN & MEAN \\
\hline & \multicolumn{3}{|c|}{ FEBRUARY } & \multicolumn{3}{|c|}{ MARCH } & \multicolumn{3}{|c|}{ APRIL } & \multicolumn{3}{|c|}{ MAY } \\
\hline 1 & 118 & 117 & 118 & 77 & 73 & 75 & 125 & 107 & 116 & 115 & 90 & 101 \\
\hline 2 & 118 & 116 & 117 & 85 & 75 & 80 & 137 & 114 & 125 & 97 & 88 & 92 \\
\hline 3 & 116 & 112 & 113 & 85 & 83 & 84 & 132 & 110 & 119 & 93 & 79 & 85 \\
\hline 4 & 112 & 104 & 107 & 84 & 82 & 82 & 123 & 110 & 116 & 80 & 74 & 76 \\
\hline 5 & 104 & 103 & 104 & 88 & 82 & 85 & 123 & 111 & 116 & 85 & 75 & 79 \\
\hline 6 & 109 & 104 & 107 & 99 & 87 & 94 & 133 & 111 & 120 & 96 & 80 & 86 \\
\hline 7 & 111 & 109 & 111 & 104 & 99 & 101 & 135 & 115 & 125 & 96 & 85 & 91 \\
\hline 8 & 112 & 111 & 111 & 108 & 103 & 106 & 132 & 115 & 122 & 88 & 75 & 80 \\
\hline 9 & 113 & 112 & 113 & 109 & 105 & 107 & 129 & 113 & 119 & 87 & 74 & 78 \\
\hline 10 & 117 & 113 & 115 & 118 & 107 & 113 & 131 & 112 & 121 & 93 & 81 & 87 \\
\hline 11 & 118 & 116 & 117 & 124 & 117 & 121 & 131 & 111 & 120 & 90 & 81 & 85 \\
\hline 12 & 121 & 112 & 118 & 128 & 121 & 125 & 133 & 111 & 119 & 99 & 77 & 85 \\
\hline 13 & 122 & 112 & 116 & 124 & 112 & 115 & 130 & 106 & 112 & 99 & 74 & 80 \\
\hline 14 & 118 & 108 & 113 & 113 & 105 & 108 & 130 & 104 & 112 & 95 & 73 & 81 \\
\hline 15 & 131 & 109 & 120 & 112 & 105 & 107 & 133 & 105 & 113 & 102 & 76 & 83 \\
\hline 16 & 132 & 116 & 123 & 112 & 91 & 102 & 132 & 92 & 106 & 103 & 77 & 86 \\
\hline 17 & 123 & 112 & 117 & 106 & 94 & 101 & 116 & 81 & 92 & 102 & 78 & 91 \\
\hline 18 & 120 & 111 & 116 & 110 & 97 & 104 & 103 & 80 & 87 & 90 & 81 & 84 \\
\hline 19 & 113 & 100 & 105 & 129 & 100 & 115 & 87 & 65 & 75 & 90 & 71 & 78 \\
\hline 20 & 113 & 104 & 109 & 131 & 112 & 121 & 82 & 63 & 72 & 79 & 63 & 69 \\
\hline 21 & 116 & 106 & 112 & 123 & 102 & 113 & 80 & 71 & 75 & 77 & 63 & 69 \\
\hline 22 & 118 & 105 & 113 & 112 & 93 & 101 & 83 & 71 & 75 & 75 & 61 & 66 \\
\hline 23 & 110 & 102 & 104 & 102 & 64 & 75 & 90 & 75 & 81 & 73 & 60 & 63 \\
\hline 24 & 103 & 76 & 83 & 76 & 64 & 70 & 93 & 81 & 85 & 74 & 61 & 64 \\
\hline 25 & 96 & 81 & 90 & 77 & 69 & 73 & 95 & 82 & 88 & 75 & 62 & 65 \\
\hline 26 & 101 & 95 & 98 & 77 & 69 & 74 & 90 & 70 & 77 & 72 & 62 & 65 \\
\hline 27 & 101 & 77 & 85 & 84 & 69 & 77 & 75 & 69 & 71 & 73 & 60 & 63 \\
\hline 28 & 80 & 74 & 77 & 89 & 76 & 85 & 74 & 68 & 71 & 69 & 58 & 61 \\
\hline 29 & -- & -- & $\ldots$ & 93 & 83 & 88 & 86 & 68 & 76 & 74 & 58 & 62 \\
\hline 30 & $\cdots$ & -- & $-\cdot$ & 107 & 93 & 99 & 110 & 80 & 96 & 74 & 61 & 64 \\
\hline 31 & -- & -- & & 114 & 99 & 107 & -- & -- & $\cdots$ & 76 & 61 & 65 \\
\hline 1ONTH & 132 & 74 & 108 & 131 & 64 & 97 & 137 & 63 & 100 & 115 & 58 & 77 \\
\hline
\end{tabular}




\section{Appendix 13-Example of an ADAPS daily-values table (Continued)}

UNITED STATES DEPARTMENT OF THE INTERIOR - GEOLOGICAL SURVEY - WASHINGTON STATE NWIS 10/31/2000

STATION NUMBER 12113390 DUWAMISH R AT GOLF COURSE AT TUKWILA, WA STREAM SOURCE AGENCY USGS LATITUDE 472845 LONGITUDE 1221527 DRAINAGEAREA 461 DATUM STATE 53 COUNTY 033 FROM EDL

SPECIFIC CONDUCTANCE (MICROSIEMENS/CM AT 25 DEG. C), WATER YEAR OCTOBER 1998 TO SEPTEMBER 1999

\begin{tabular}{|c|c|c|c|c|c|c|c|c|c|c|c|c|}
\hline \multirow[t]{2}{*}{ DAY } & MAX & MIN & MEAN & MAX & MIN & MEAN & MAX & MIN & MEAN & MAX & MIN & MEAN \\
\hline & \multicolumn{3}{|c|}{ JUNE } & \multicolumn{3}{|c|}{ JULY } & \multicolumn{3}{|c|}{ AUGUST } & \multicolumn{3}{|c|}{ SEPTEMBER } \\
\hline 1 & 76 & 62 & 66 & 135 & 86 & 104 & 230 & 156 & 174 & 254 & 151 & 174 \\
\hline 2 & 75 & 61 & 64 & 139 & 101 & 112 & 239 & 150 & 168 & 264 & 154 & 178 \\
\hline 3 & 82 & 62 & 68 & 124 & 94 & 102 & 263 & 149 & 203 & 264 & 161 & 180 \\
\hline 4 & 103 & 67 & 83 & 106 & 79 & 89 & 263 & 151 & 172 & 272 & 163 & 193 \\
\hline 5 & 101 & 80 & 87 & 98 & 77 & 82 & 193 & 144 & 170 & 276 & 162 & 187 \\
\hline 6 & 99 & 77 & 82 & 98 & 76 & 81 & 193 & 133 & 155 & 268 & 160 & 189 \\
\hline 7 & 102 & 75 & 80 & 111 & 77 & 86 & 167 & 127 & 142 & 248 & 160 & 180 \\
\hline 8 & 95 & 60 & 70 & 113 & 80 & 87 & 159 & 119 & 132 & 386 & 159 & 199 \\
\hline 9 & 79 & 60 & 64 & 146 & 80 & 104 & 190 & 125 & 149 & 306 & 161 & 193 \\
\hline 10 & 92 & 61 & 73 & 151 & 107 & 123 & 192 & 130 & 145 & 260 & 161 & 189 \\
\hline 11 & 103 & 71 & 79 & 147 & 105 & 113 & 233 & 140 & 171 & 256 & 160 & 190 \\
\hline 12 & 100 & 67 & 75 & 156 & 105 & 111 & 248 & 151 & 175 & 240 & 161 & 182 \\
\hline 13 & 89 & 66 & 70 & 143 & 102 & 111 & 241 & 151 & 168 & 222 & 160 & 176 \\
\hline 14 & 91 & 66 & 71 & 147 & 99 & 111 & 232 & 149 & 174 & 171 & 157 & 162 \\
\hline 15 & 94 & 66 & 71 & 148 & 95 & 105 & 199 & 145 & 164 & 167 & 157 & 162 \\
\hline 16 & 93 & 55 & 64 & 144 & 95 & 114 & 202 & 148 & 175 & 170 & 154 & 160 \\
\hline 17 & 81 & 55 & 59 & 112 & 81 & 91 & 215 & 148 & 168 & 178 & 146 & 163 \\
\hline 18 & 88 & 58 & 65 & 113 & 83 & 92 & 220 & 144 & 161 & 171 & 144 & 159 \\
\hline 19 & 116 & 61 & 82 & 129 & 91 & 101 & 250 & 150 & 170 & 162 & 143 & 152 \\
\hline 20 & 116 & 86 & 91 & 146 & 93 & 105 & 244 & 151 & 169 & 157 & 133 & 146 \\
\hline 21 & 114 & 82 & 94 & 147 & 97 & 107 & 263 & 156 & 193 & 159 & 131 & 145 \\
\hline 22 & 114 & 87 & 98 & 138 & 91 & 102 & 253 & 160 & 181 & 131 & 105 & 122 \\
\hline 23 & 123 & 91 & 103 & 145 & 91 & 105 & 273 & 162 & 195 & 108 & 103 & 105 \\
\hline 24 & 112 & 72 & 85 & 153 & 97 & 110 & 260 & 162 & 182 & 363 & 99 & 133 \\
\hline 25 & 81 & 66 & 72 & 150 & 96 & 110 & 251 & 162 & 178 & 163 & 107 & 123 \\
\hline 26 & 93 & 67 & 77 & 169 & 96 & 124 & 268 & 160 & 184 & 191 & 106 & 129 \\
\hline 27 & 99 & 76 & 82 & 219 & 122 & 160 & 235 & 158 & 176 & 175 & 110 & 118 \\
\hline 28 & 103 & 77 & 85 & 238 & 168 & 188 & 250 & 158 & 177 & 172 & 110 & 125 \\
\hline 29 & 103 & 77 & 83 & 249 & 165 & 192 & 258 & 161 & 183 & 207 & 112 & 135 \\
\hline 30 & 117 & 79 & 92 & 244 & 167 & 193 & 266 & 159 & 186 & 163 & 116 & 134 \\
\hline 31 & -- & --. & -.- & 254 & 159 & 184 & 230 & 153 & 170 & $\cdots$ & $-\cdot$ & -- \\
\hline MONTH & 123 & 55 & 78 & 254 & 76 & 116 & 273 & 119 & 171 & 386 & 99 & 159 \\
\hline
\end{tabular}




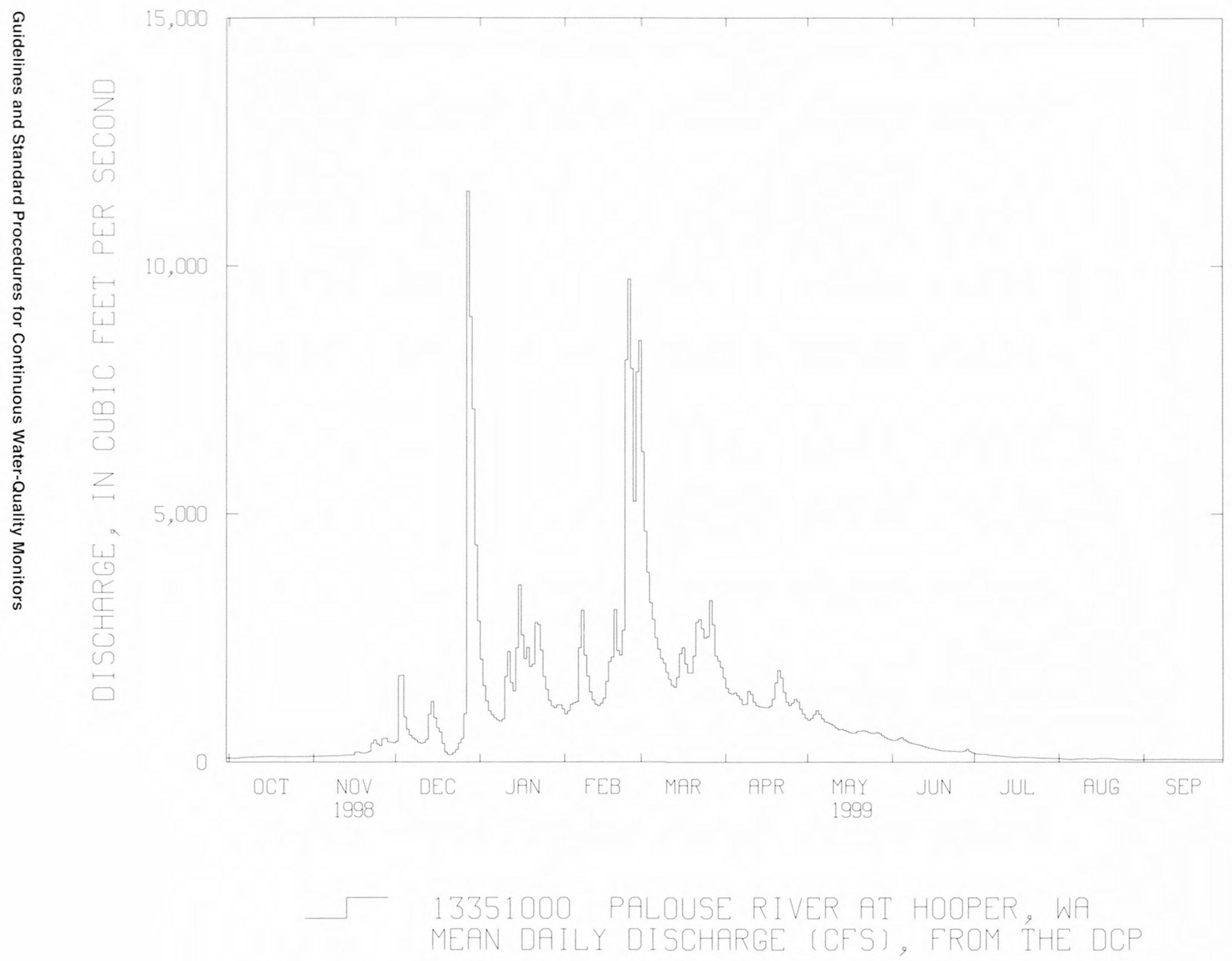

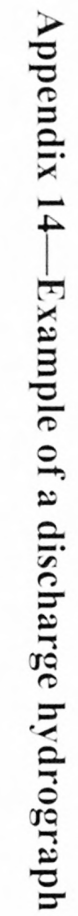


Appendix 15-Example of a review graph for an individual water-quality property

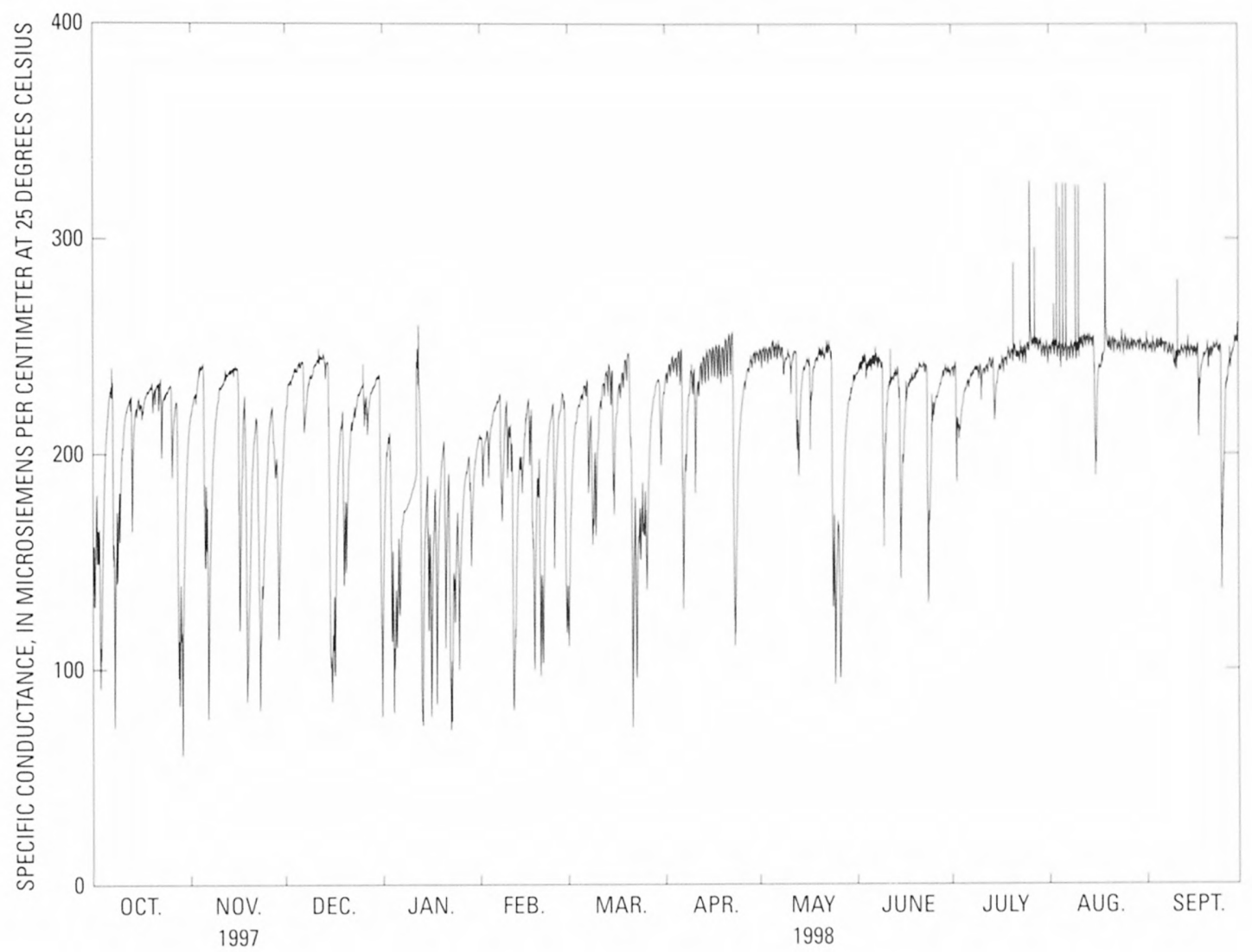




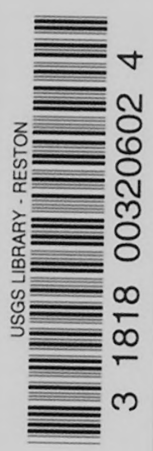

